\title{
Scleria (Cyperaceae) in the state of Pará, Amazon, Brazil
}

\section{Layla Jamylle Costa Schneider ${ }^{1 *}$ (1) and André dos Santos Bragança Gil ${ }^{2}$ (])}

Received: May 11, 2020

Accepted: October 20, 2020

\begin{abstract}
The present study analyzes the diversity of Scleria in the state of Pará and presents taxonomic treatments for all recorded species. The analysis was based on extensive herbarium studies (CEN, HBRA, HCJS, HSTM, IAN, IBGE, INPA, MFS, MG, RB, and UB) and field expeditions to several municipalities of the state of Pará. Specimens were identified using relevant literature, protologues, and type specimens available online. We recognize 30 species of Scleria arranged in two subgenera and nine sections. Four species (i.e., Scleria arguta, S. burchellii, S. longigluma, and S. vaginata) represent new records for Pará, and a new species is proposed (i.e., Scleria sp.). An identification key, descriptions, illustrations, and comments on diagnostic characters, geographic distribution and habitat for all species are also provided.
\end{abstract}

Keywords: Cyperoideae, flora, neotropics, Poales, Scleriae, sedges

\section{Introduction}

Scleria is one of the largest genera of Cyperaceae, comprising about 260 species (Govaerts 2019). It has a pantropical distribution, occurring in warm and temperate climates in the Americas, Africa, Asia, and Oceania (Core 1936; Ohwi 1971; Hennessy 1985; Govaerts 2019). In Brazil, Scleria is the fourth largest genera of Cyperaceae (72 spp.), only surpassed by Rhynchospora (168 spp.), Cyperus (122 spp.) and Eleocharis (79 spp.) (Schneider \& Gil 2020a; Thomas et al. 2020; Matzenauer et al. 2020; Nunes et al. 2020). Species of Scleria can be found growing in rainforests or seasonally dry forests, swamps, and moist, waterlogged, sandy or rocky soils (Goetghebeur 1998; Bauters et al. 2016). Scleria is currently placed in subfamily Cyperoideae Kostel, in the monogeneric tribe Sclerieae Nees. The tribe can be morphologically characterized by its paniculate inflorescences, bisexual or unisexual spikelets, and the nutlet's base covered by a structure called hypogynium (Goetghebeur 1998; Muasya et al. 2009). Phylogenetic studies have demonstrated the monophyly of the genus, which is divided into four subgenera: Scleria subg. Browniae (one section), S. subg. Hypoporum (further divided into three sections), S. subg. Scleria (further divided into 12 sections), and $S$. subg. Trachylomia (one section) (Bauters et al. 2016; 2018).

Several relevant taxonomic studies on Scleria have been carried out in some regions of the American continent (e.g., Koyama 1984; Adams 1994; Camelbeke \& Goetghbeur 1998; Camelbeke \& Goetghbeur 2002; Camelbeke et al. 2003). The study by Core (1936) is of particular relevance since it addressed the genus for the entire continent. Furthermore, Core (1952) presented a detailed taxonomic account for Scleria in Brazil, presenting an identification key, typification, and data on the geographic distribution of all 65 species recognized by him. Later, the genus was treated, in large part, by floras and local taxonomic studies,

1 Pós-graduação em Ciências Biológicas, Universidade Federal Rural da Amazônia, Museu Paraense Emilio Goeldi, 66077-830, Belém, PA, Brazil 2 Coordenação de Botânica, Museu Paraense Emílio Goeldi, 66077-830, Belém, PA, Brazil

* Corresponding author: laylaschneider11@gmail.com 
such as: (1) Muniz \& Shepherd 1987 - State of São Paulo; (2) Simpson 2006 - Reserva Ducke, State of Amazonas; (3) Araújo 2009 - Distrito Federal; (4) Nunes \& Prata 2013 State of Sergipe; (5) Barros 1960 and Affonso et al. 2015 - State of Santa Catarina; and (6) Araújo \& Trevisan 2018 State of Mato Grosso do Sul). More recently, Scleria received an updated account of the Brazilian species, as part of the Flora do Brasil 2020 project (Schneider \& Gil 2020a). Nevertheless, there are still few studies developed in the Brazilian Amazon region.

Some local studies have been developed focusing on the Cyperaceae in the state of Pará, such as: (1) Nunes et al. (2016) for the "cangas" of Serra dos Carajás; (2) Silva et al. (2021) for the "campos de natureza" in the municipality of Cametá; and (3) Schneider et al. (2017), Maciel-Silva et al. (2018), and Schneider \& Gil (2020b) focusing on Rhynchospora, Eleocharis, and Scleria for the "restingas", respectively. These studies provided taxonomic and nomenclatural novelties, and presented new records for the Flora of Pará, which demonstrates the need for further taxonomic research. Thus, the study aims to analyze the diversity of Scleria in the state of Pará by presenting a taxonomic treatment of the recorded species. We provide an identification key, descriptions, comments, illustrations, and data of geographic distribution and habitat, for all accepted species.

\section{Materials and methods}

\section{Study area}

The state of Pará is located in the Northern region of Brazil and comprises 144 municipalities distributed in 1,248 thousand $\mathrm{km}^{2}$ (IBGE 2015; 2016). It is nested in the Amazon Forest biome, with a predominant vegetation cover of dense or open rainforests. Furthermore, the State also presents areas of seasonally dry forests, "campinaranas", "campinas", savannahs, "restingas", and mangroves (IBGE 2004). The State's topology is often low and flat, with around $80 \%$ of its territory reaching up to $300 \mathrm{~m}$ above the sea level (Lima 2013). The highest altitudes, between 600 to $800 \mathrm{~m}$ above the sea level, are represented by the Amapá and Cachimbo Hills, Carajás, and the Cubencranquem Mountains (Furtado \& Ponte 2013; Lima 2013). The climate is classified as Köppen category A: a rainy tropical climate, without a cold season. It also presents three climate subtypes (i.e., Af, Am, and Aw), with elevated rainfall, and an annual "dry" period (Bastos 1982). In the state of Pará, the rainy season extends from December to May, while the drier season extends from June to November. The annual rainfall ranges from 1200 to $3600 \mathrm{~mm}$, with an average temperature of $25^{\circ} \mathrm{C}$ (Moraes et al. 2005; Lopes et al. 2013).

\section{Taxonomic treatment}

The examined specimens list was compiled based on the identifications made at the consulted herbaria collections (i.e., CEN, HBRA, HCJS, HSTM, IAN, IBGE, INPA, MFS, MG, RB, and UB; acronyms according to Thiers 2020, continuously updated), and complemented by specimens collected during the field expeditions to the municipalities of Acará, Belém, Cachoeira do Arari, Cametá, Maracanã, Marapanim, Melgaço, Novo Progresso, Parauapebas, Salinópolis, Salvaterra, and São Geraldo do Araguaia. The specimens were identified using specialized literature (Core 1936; Camelbeke \& Goetghebeur 1998; 2002; Camelbeke 2002; Bauters et al. 2016), the protologues available (BHL 2019; Botanicus.org 2019; Open Library 2018), and, when possible, supported by type specimens available online (i.e., B, BM, GH, K, M, MA, NY, P, PH, PI, S, SBT and US, acronyms and herbaria information according to Thiers 2020, continuously updated; JSTOR Global Plants 2020). Abbreviation of the original publication and authors follows Tropicos.org (2019) and the World Checklist of Selected Plant Families (WCSP 2019). The adopted infrageneric classification follows Bauters et al. $(2016,2018)$. The most relevant synonyms of the names treated in the present study are available at the Flora do Brasil 2020 website (Schneider \& Gil 2020a).

General morphological terminology follows Harris \& Harris (2001) and Gonçalves \& Lorenzi (2011); leaf, inflorescence, and fruit terminology follow Ahumada (2007), Ahumada \& Vegetti (2009), and Espinoza et al. (2016); and indument terminology follows Cabrera Ziri \& Tillett (2016). The description of the genus is based on the examined specimens. The measurements and descriptions of the leaves were taken from the leaves with developed blades, and of the involucral bracts and glumes were taken from the basalmost ones from the primary panicles and spikelets, respectively. The nutlets measurements include the hypogynium, and also the cupule when it was adnate to the hypogynium and nutlet. The sequence of the structure's format and indument follows the frequency observed in the specimens (e.g., glabrous to pubescent). In cases where the specimens lacked some structure used in the descriptions, supplementary descriptions are supplied with the available literature or additional materials.

The selected material contemplates, for each species, one specimen from every municipality in which the species was registered. Furthermore, all specimens that lacked municipality information in the labels (i.e., no locality/n.l.), or in which it was not possible to undoubtedly determine the municipality, were cited in the selected material list. All examined specimens are cited in the exsiccate List S1 in supplementary material. The specimens that were too incomplete to allow determination were excluded from this taxonomic treatment and cited in the list of excluded materials (List S2 in supplementary material). 
The geographic distribution and habitat data were acquired from the labels of the examined exsiccates, plus data from the literature (e.g., Kessler 1987; Camelbeke \& Goetghebeur 1998; Acevedo-Rodríguez \& Strong 2012; Nunes \& Prata 2013), specialized websites (WCSP 2019; SpeciesLink 2019; Flora do Brasil 2020), and field notes.

Photographs of the fruits were taken using a stereoscopic microscope Leica M205A at the Coordenação de Ciências da Terra e Ecologia - Museu Paraense Emílio Goeldi /MPEG, while the images of the inflorescences in the herbarium specimens were obtained through a scanner Epson J181A at the Museu Paraense Emílio Goeldi Herbaria (MG) - MPEG.

\section{Results and discussion}

We examined around 600 specimens, which resulted in the recognition of 30 species of Scleria for the state of Pará, distributed in S. subg. Hypoporum (eight spp.) and S. subg. Scleria (22 spp.), and nine sections [i.e., S. subg. H. sect. Hypoporum, S. subg. H. sect. Lithospermae, S. subg. S. sect. Foveolidia, S. subg. S. sect. Hymenolytrum, $S$. subg. S. sect. Margaleia, S. subg. S. sect. Melanomphalae, S. subg. S. sect. Ophryoscleria, S. subg. S. sect. Schizolepis and $S$. subg. S. sect. Scleria]. According to Schneider \& Gil (2020a), 26 species of Scleria are recorded for the state of Pará. Nonetheless, the present study does not confirm the occurrence of $S$. macrogyne, S. ramosa, and S. verticillata, for the State. Alternatively, four new State records [i.e., S. arguta, S. burchellii, S. longigluma, and S. vaginata] are made. Finally, we found a specimen notably distinct from all the species recognized by us for the $S$ tate. This specimen is placed into $S$. subg. H. sect. Hypoporum, due to its spiciform inflorescence, androgynous spikelets, and reduced hypogynium. In the present work, it is treated as Scleria sp., awaiting further ongoing studies aiming to verify its identity.
SCLERIA P.J.Bergius, Kongl. Vetensk. Acad. Handl. 26: 142.1765.

(Figs. 1-7)

Herbs perennial or annual, monoecious, rarely dioecious, erect to climbing, caespitose or solitary; rhizome present or absent, if present, knotted or not. Stem triangular in cross-section, glabrous to pubescent, angles ciliate or glabrous, armed or not. Leaves basal and cauline, basal ones commonly lacking developed blades, cauline ones with developed blades. Sheath membranous to chartaceous, glabrous to pubescent, basal ones unwingued and cauline winged or not; contraligule concave to long-lanceolate, apex glabrous or ciliate, membranous appendage present or not; ligule of trichomes present or not. Blade linear to lanceolate, rarely oblong, glabrous or pubescent, margins armed or not, rarely ciliate, apex entire or pseudopremorse (i.e., irregularly truncate). Involucral bracts foliaceous, sometimes glumaceous, linear or lanceolate, rarely narrowelliptic or oblong. Inflorescence terminal, paniculate or spiciform (i.e., with congested fascicles), branched or not. Spikelets unisexual or bisexual; glumes distichous to spiral. Flowers unisexual, staminate with $1-3$ stamens, pistillate with 3 stigmas. Nutlet globose to ellipsoid, circular or triangular in cross-section, base with or without pores, surface smooth (i.e., not ornate), crested, reticulate, rugulose or papillose, glabrous to puberulous. Stylobase at nutlet apex present or not, if present, persistent or deciduous. Hypogynium reduced (i.e., not covering the fruit base, represented by a papillose region) or developed (i.e., covering the fruit base), if developed annular, zoniform or trilobed, lobes rounded to laciniate. Cupule adnate to the fruit and hypogynium or rachilla, concave or flat, margin entire or trilobed, glabrous or ciliate.

Key to species of Scleria from state of Pará, Amazon, Brazil

1. Herbs dioecious (i.e., S. subg. Scleria sect. Scleria) 2

1'. Herbs monoecious

2. Herbs climbing; inflorescence $2.4-14.3 \times 1.5-3.5 \mathrm{~cm}$, emerging from the intermediate stem nodes

(25) S. tenacissima (Nees) Steud.

2'. Herbs erect; inflorescence $15-27 \times 6-7 \mathrm{~cm}$, emerging from the terminal stem nodes

(1) S. amazonica Camelbeke, Strong \& Goetghebeur

3. Spikelets androgynous; hypogynium reduced, not covering the fruit base (i.e., S. subg. Hypoporum (Nees) C.B.Clarke) .... 4

3'. Spikelets pistillate, staminate or subandrogynous; hypogynium developed, covering the fruit base (i.e., S. subg. Scleria)

4. Inflorescences paniculate; nutlets ellipsoid, hypogynium black (i.e., S. subg. H. sect. Lithospermae (C.B.Clarke) C.B.Clarke)

(13) S. lithosperma (L.) Sw.

4'. Inflorescences spiciform; nutlets subglobose, globose or obovoid, hypogynium light brown to dark brown (i.e., $S$. subg. H. sect. Hypoporum)

5. Rhizome present; stylobase present at nutlet apex.

(6) S. distans Poir.

5'. Rhizome absent; stilobase absent at nutlet apex...

6. Glumes' midrib pilose, unarmed; nutlet circular or subcircular in cross-section

6'. Glumes' midrib glabrous, armed; nutlet subtriangular in cross-section 
7. Nutlet smooth

7'. Nutlet crested and papillose or slightly papillose

(9) S. hirtella Sw.

8. Contraligule's membranous appendage present; rachis angles ciliate and/or armed..... (10) S. interrupta Rich.

8'. Contraligule's membranous appendage absent; rachis angles glabrous and unarmed ....

9. Contraligule's membranous appendage $0.2-0.5 \mathrm{~mm}$ long; spikelets $2.1-3.3 \mathrm{~mm}$ long; stamen 1 per flower; nutlet completely ornate

(26) S. tenella Kunth

9'. Contraligule's membranous appendage 1-1.5 mm long; spikelet 4.5-5.5 mm long; stamens 2 per flower; nutlet partially ornate, with one smooth longitudinal stripe in each nutlet side.

10. Inflorescences branched; stamens 3 per flower; nutlets subglobose

(4) S. burchellii C.B.Clarke

10'. Inflorescences unbranched; stamens 2 per flower; nutlets obovoid

(19) S. pusilla Pilg.

11. Spikelets staminate and subandrogynous in distinct panicles

(30) Scleria sp.

11'. Spikelets staminate and subandrogynous not in distinct panicles

(3) S. bracteata Cav.

12. Leaf-blades pseudopremorse at apex 12

12'. Leaf-blade entire at apex

13. Stylobase present at nutlet apex, hypogynium lobes rounded, cupule persisting at the nutlet, margin ciliate or ciliolate (i.e., S. subg. S. sect. Ophryoscleria (Nees) C.B.Clarke)

13'. Stylobase absent at nutlet apex, hypogynium lobes laciniate, cupule persisting at the rachilla, margin glabrous (i.e., S. subg. S. sect. Schizolepis (Schrad. ex Nees) C.B.Clarke)

14. Leaf-blades $0.8-2.2 \mathrm{~cm}$ wide; staminate spikelets $1.3-3 \mathrm{~mm}$ long; stylobase $0.5-1 \mathrm{~mm}$ long

14'. Leaf-blades (2.8-)3.5-6.9 cm wide; staminate spikelets $3.5-4.7 \mathrm{~mm}$ long; stylobase $1.5-2 \mathrm{~mm}$ long ......

15. Contraligule 3.1-5(-31) mm long; leaf-blades adaxially lacking two pubescent ribs; cupule trichomes hyaline to brown

(17) S. microcarpa Nees ex Kunth

15'. Contraligule 36-40 mm long; leaf-blades adaxially with two pubescent ribs; cupule trichomes golden and red ..

(18) S. mitis P.J.Bergius

16. Leaf-blades linear to lanceolate; stylobase conical, persistent

16'. Leaf-blades oblong; stylobase terete, deciduous

(15) S. macrophylla J.Presl \& C.Presl

17. Leaf-sheaths chartaceous; nutlet crested-reticulate, puberulous

(23) S. sprucei C.B.Clarke

17'. Leaf-sheaths papyraceous; nutlet smooth, glabrous

(2) S. arguta (Nees) Steud.

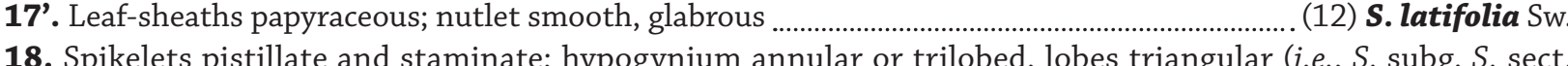
Hymenolytrum (Schrad. ex Nees) Core) ............................................................................................................................... 19

18'. Spikelets subandrogynous and staminate; hypogynium zoniform or trilobed, lobes rounded or oblong .......... 27

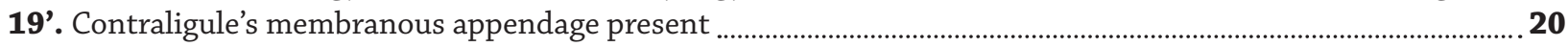

19. Contraligule's membranous appendage absent ……………………………………………………………………….... 26

20. Herbs climbing .................................................................................................................................................. 21

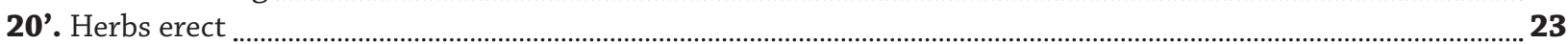

21. Basal and terminal sheaths unwinged; hypogynium annular rarely trilobed

(22) S. secans (L.) Urb.

21'. Basal sheaths unwinged and distal sheaths winged; hypogynium distinctly trilobe

22

22. Leaf-sheaths glabrescent to puberulous, ligule absent; hypogynium lobes with laciniate apex

(16) S. martii (Nees) Steud.

22'. Leaf-sheaths glabrous, ligule present; hypogynium lobes with entire apex

(29) S. violacea Pilg.

23. Leaf-blades $2.7-3.3 \mathrm{~cm}$ wide; third staminate glume with apiculate apex.

(24) S. stipularis Nees

23'. Leaf-blades $0.5-1.5 \mathrm{~cm}$ wide; third staminate glume with mucronate apex

24

24. Stems glabrescent; leaf-sheaths winged; glumes light brown with red dots

(21) S. scabra Willd.

24'. Stems glabrous; basal leaf-sheaths unwinged and distal ones winged; glumes vinaceous to light brown with vinaceous maculae

25. Leaf-sheaths glabrescent to puberulous, ligule absent; hypogynium lobes with laciniate apex

(16) S. martii (Nees) Steud.

25'. Leaf-sheaths glabrous, ligule present; hypogynium lobes with entire apex

(29) S. violacea Pilg.

26. Ligule absent; inflorescence $3-9.1 \mathrm{~cm}$ long, rachis glabrous; hypogynium trilobed

(5) S. cyperina Willd. ex Kunth

26'. Ligule present; inflorescence $24.8-39 \mathrm{~cm}$ long; rachis pubescent or puberulous; hypogynium annular

(28) S. vaginata Steud.

27. Spikelets 1-1.5 cm long (i.e., S. subg. S. sect. Melanomphalae Bauters)

(14) S. longigluma Kük.

27'. Spikelets 3-6.1 mm long 
28. Herbs annual; hypogynium zoniform (i.e., S. subg. S. sect. Margaleia Raf.) (11) S. lacustris C. Wright

28'. Herbs perennial; hypogynium trilobed

29. Contraligule's membranous appendage present; hypogynium lobes oblong (i.e., S. subg. S. sect. Foveolidia Raf.) .

(20) S. reticularis Michx.

29'. Contraligule's membranous appendage absent; hypogynium lobes rounded (i.e., S. subg. S. sect. Scleria) ....... 30

30. Herbs climbing; leaf-sheaths chartaceous; stamens 3 per flower (7) S. flagellum-nigrorum P.J.Bergius

30'. Herbs erect; leaf-sheaths papyraceous; stamen 1 per flower 31

31. Leaf-sheaths unwinged; glumes puberulous, staminate spikelets $5.3-6.1 \mathrm{~mm}$ long; nutlets ovoid, subtriangular in cross-section, crested (27) S. triquetra M.T.Strong

31'. Basal leaf-sheaths unwinged and terminal ones winged; glume glabrous, staminate spikelets 3.1-4.2 mm long; nutlets subglobose, circular in cross-section, smooth

(8) S. gaertneri Raddi

1. Scleria amazonica Camelbeke, Strong \& Goetghebeur, Novon 7(2): 98. 1997.

(Figs. 1A, 6A)

Herbs $68.2-85.3 \mathrm{~cm}$ tall, perennial, dioecious, erect, solitary; rhizomes knotted, sometimes not. Stems 2.5-9 mm wide, pubescent to puberulous, rarely pilose, angles glabrous, armed. Leaf-sheaths $3.5-6.4 \mathrm{~cm}$ long, chartaceous, pubescent, unwinged, margins glabrous, armed; ligule only at the base of the leaf-blade, trichomes $0.5-1 \mathrm{~mm}$ long, dense, golden. Contraligules 6-7 mm long, acute, apex ciliate to glabrous, membranous appendage absent. Leaf-blades $26.8-38.9 \times 0.6-0.9 \mathrm{~cm}$, linear, continuous to the sheath, abaxially glabrous, midrib armed, adaxially glabrous, midrib glabrous to puberulous, margins glabrous and armed, apex entire. Involucral bracts $2.2-21.6 \times$ $0.3-0.8 \mathrm{~cm}$, foliaceous, linear. Inflorescences $15-27 \times 6-7$ $\mathrm{cm}$, paniculate; rachis puberulous, angles glabrous to ciliate, and unarmed. Spikelets staminate or pistillate, in distinct specimens. Staminate spikelets not seen. Pistillate spikelets $5-7.5 \times 1.1-1.5 \mathrm{~mm}$, terete to lanceoloid, sessile or pedicellate; pedicel up to $2.5 \mathrm{~mm}$ long. Glumes light brown, puberulous to pubescent, midrib pubescent to glabrous, unarmed, margins ciliolate to glabrous, apex mucronulate. Nutlets $2.3-2.5 \times 1.8-2 \mathrm{~mm}$, subglobose, subtriangular to circular in cross-section, white, surface crested-reticulate, glabrous, base lacking pores, apex apiculate. Stylobase absent. Hypogynium developed, annular, lobes absent, yellowish-brown, margin revolute, apex entire. Cupules flat, entire, persisting at the raquilla, margin glabrous.

Supplementary description: Stamens 3 per flower (Camelbeke et al. 1997).

Selected material: BRAZIL. PARÁ: Cametá, Curuçambaba, 0208'34.28" S, 49¹7'59.25” W, 23/I/2017, fl. and fr., Braga-Silva, C.L. et al. 76 (MG).

Comment: Scleria amazonica is characterized by its erect growth, sheaths unwinged, ligulate, unisexual paniculate inflorescences (Fig. 1A), crested-reticulate nutlets (Fig. 6B), and dioecy. Dioecy in Scleria is poorly understood, so far, being recorded for only two species, S. sphacelata F.Mueller (Australia) and S. tenacissima (Nees) Steud. (South America). Camelbeke et al. (1997) described S. amazonica based on herborized materials and suggested that this species was dioecious, because the most of analyzed specimens presented unisexual inflorescences, and more material should be collected to confirm the dioecy of the species. In the state of Pará, three specimens were examined from the same municipality, collected between January and July. All specimens present pistillate inflorescences, which gives further support to the dioecy mentioned in the original description (Camelbeke et al. 1997). Scleria amazonica resembles $S$. tenacissima (Nees) Steud. due to their dioecy, leaf-sheaths unwinged and ligulate, and especially due to the presence of an annular hypogynium and crested-reticulate nutlets (Figs. $6 \mathrm{~A}, 7 \mathrm{~J})$. However, S. tenacissima has a climbing growth, with inflorescences emerging from the intermediate stem nodes (such as axillary buds - Fig. 5D), while S. amazonica presents erect growth and inflorescence emerging from the terminal stem nodes (Fig. 1A). Both species are included in the $S$. subg. S. sect. Scleria, which is supported by molecular and morphological data (Bauters et al. 2016). Nonetheless, species of $S$. subg. S. sect. Scleria are mainly recognized for their trilobed hypogynium with a revolute margin, which is not observed in the aforementioned species. In fact, the hypogynium of $S$. amazonica and $S$. tenacissima is annular, like those seen in some members of S. subg. S. sect. Hymenolytrum, such as S. secans (L.) Urb. (Fig. 7G) and S. vaginata Steud. (Fig. 7M). Furthermore, the hypogynium of $S$. amazonica and $S$. tenacissima also shares with some members of $S$. subg. S. sect. Hymenolytrum the appearance of "smashed paper".

Distribution and habitat: Venezuela and Brazil. In Brazil, there are records in the North region (AM, RR, and PA). In the state of Pará, it occurs in "campina" vegetation, sometimes in flooded places.

2. Scleria arguta (Nees) Steud., Syn. Pl. Glumac. 2: 172. 1855. $\equiv$ Schizolepis arguta Nees, Fl. Bras. 2(1): 189. 1842.

(Figs. 3A, 6B)

Herbs $1.5-2 \mathrm{~m}$ tall, perennial, monoecious, erect, solitary; rhizomes knotted. Stems ca. $4 \mathrm{~mm}$ wide, pubescent, angles glabrous, armed. Leaf-sheaths ca. 20 $\mathrm{cm}$ long, chartaceous, puberulous to glabrescent, winged, wings ca. $20 \times 0.4-0.6 \mathrm{~cm}$, margins glabrous, armed; ligule 
only at the base of the leaf-blade, trichomes $0.2-0.5 \mathrm{~mm}$ long, sparse, hyaline. Contraligules $0.5-1 \mathrm{~cm}$ long, acute, apex ciliate to glabrous, membranous appendage absent. Leaf-blades ca. $60 \times 1.2-3.1 \mathrm{~cm}$, linear, continuous to the wings of the sheaths, abaxially glabrous with two pubescent ribs toward the apex, midrib armed toward the apex, adaxially glabrescent with two armed ribs, midrib puberulous, margins glabrous and armed toward the apex, apex pseudopremorse. Involucral bracts $23.7-46.6 \times 0.7-$ $1.7 \mathrm{~cm}$, foliaceous, linear. Inflorescences $20.6-29.7 \times 13.5-$ $19.1 \mathrm{~cm}$, paniculate; rachis puberulous, angles glabrous, and unarmed. Spikelets staminate and subandrogynous, in the same panicle. Staminate spikelets $4.2-4.5 \times 1-1.3$ $\mathrm{mm}$, terete to lanceoloid, sessile to pedicellate; pedicel up to $2.3 \mathrm{~mm}$ long. Subandrogynous spikelets $\mathrm{ca} .5 \times 1 \mathrm{~mm}$, terete, sessile. Glumes brown, glabrous, midrib glabrous, armed, margins ciliolate, apex mucronate or mucronulate. Stamens 3 per flower. Nutlets 3.1-3.2 × 2-2.2 mm, ovoid to subglobose, circular in cross-section, white to light brown, surface crested-reticulate, puberulous, base lacking pores, apex apiculate. Stylobase absent. Hypogynium developed, trilobed, lobes and apex laciniate, light brown, margin flat. Cupules concave, trilobed, persisting at the rachilla, margin glabrous.

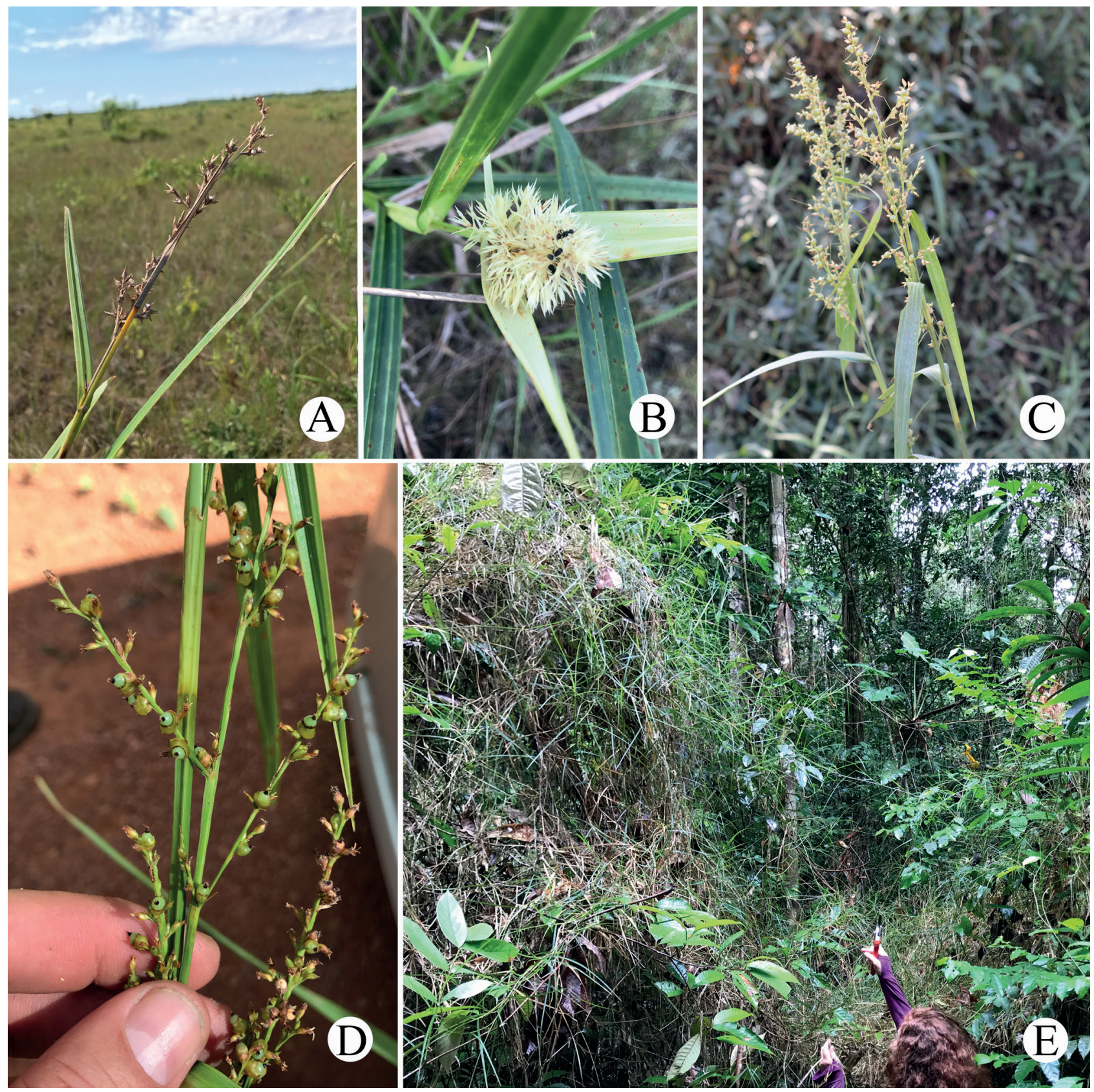

Figure 1. A. Scleria amazonica, inflorescence. B. S. cyperina, inflorescence. C. S. macrophylla, inflorescence. D. S. mitis, inflorescence. E. S. secans, habit. Images: A-B and D André Gil; $\mathbf{C}$ and E Juliene F. Maciel-Silva. 
Selected material: BRAZIL. PARÁ: [Jacareacanga], Florest and shrubby campo $S$ of Missão Cururú, at "Maloca Duas Casas", 7³5’00" S, 57³1’00” W, 9/II/1974, fl., Anderson, W.R. 10700 (IAN).

Additional examined material: BRAZIL. RONDÔNIA: Vilhena, estrada que vai para Aripuã, Fazenda Flor da Serra, $15 \mathrm{~km}$ de Vilhena, 20/05/1984, fl. and fr. Rosário, C.S. et al. 406 (MG); n.l., Sub-base proj. RADAM, Estrada Belmonte, Ig. Água Boa, 8/IX/1975, fl. and fr., Cordeiro, M.R. 750 (IAN).

Comment: Scleria arguta can be distinguished by its winged and ligulate sheaths, leaf-blades with pseudopremorse apex, paniculate inflorescences with patent and sparse branches (Fig. 3A), ovoid to subglobose nutlets with a crested-reticulate and puberulous surface, and laciniate hypogynium (Fig. 6B). Koyama (1984) synonymized $S$. arguta under $S$. myricocarpa Kunth, considering the inflorescence color of these two taxa a variable character. This interpretation was due to a supposed overlap between the coloration of the inflorescence in both species. Nonetheless, the inflorescence is traditionally interpreted as pale in $S$. arguta and as purpureous in S. myricocarpa (Core 1936). Prior to that, Nees (1842) described Schizolepis arguta and made the transfer of Scleria myricocarpa into Schizolepis.
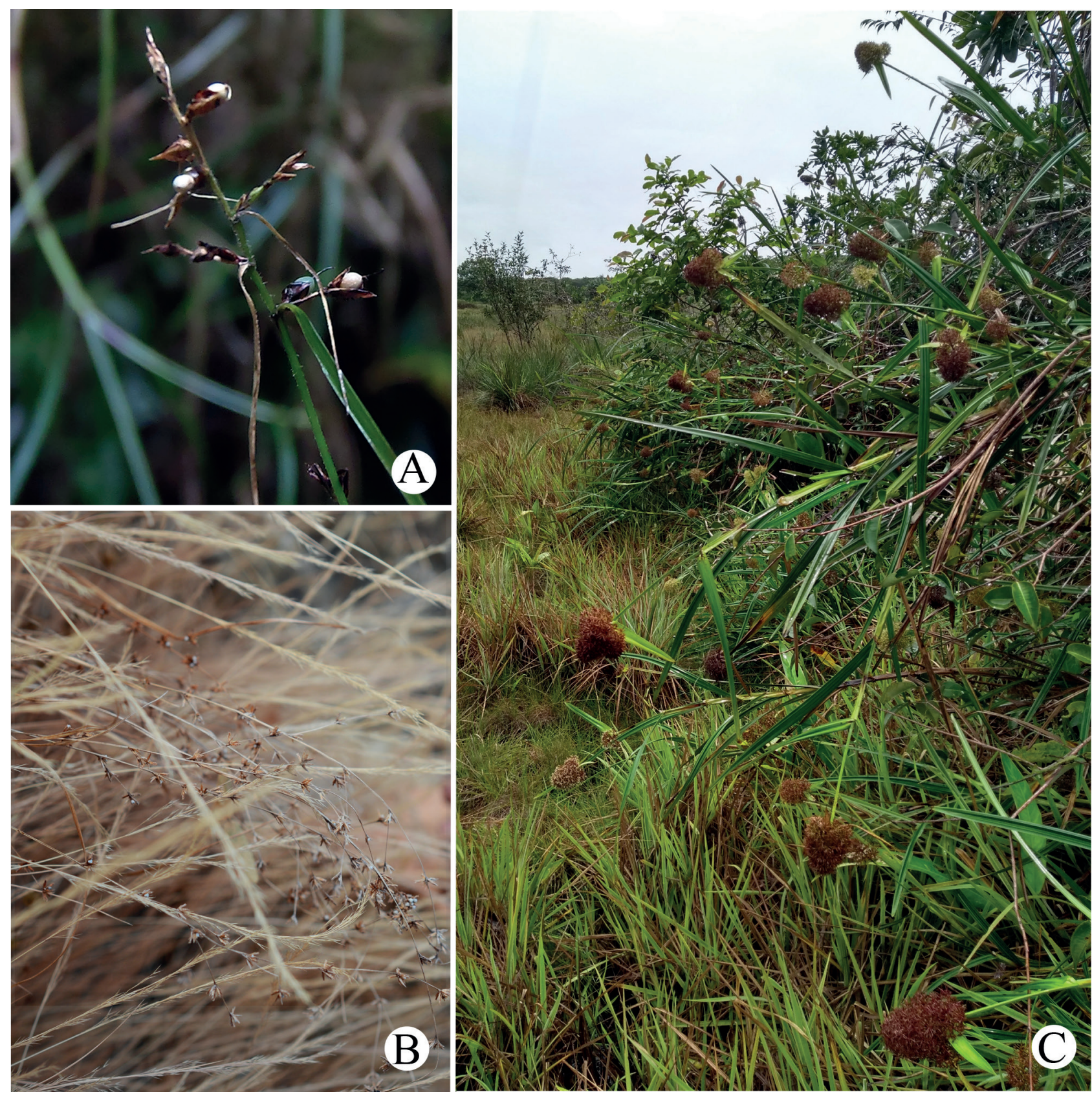

Figure 2. A. Scleria secans, inflorescence. B. S. tenella, inflorescence. C. S. violacea, habitat. Images: A-B Juliene F. Maciel Silva; C. Layla J.C. Schneider. 
He differentiated both species not only by the color of the inflorescence, but also by the larger staminate spikelets and fruits, and the rugulose nutlet in Schizolepis myricocarpa (vs. transversely rugose-cancellate in $S$. arguta). After analyzing the images of the types specimens of Scleria arguta (Sellow s.n. - K001081673) and S. myricocarpa (Luschnath s.n. F0BN011209), significant differences in the inflorescences and color patterns were noted. The first one presents lax and patent branches, while the second one presents congest and ascending to patent branches. The specimens collected at the state of Pará possess inflorescences very similar to those of type specimen of $S$. arguta. Thus, we apply this name for the species in our study, instead of S. myricocarpa as done by previous authors. Furthermore, $S$. myricocarpa and $S$. arguta are treated by us as distinct species. Nonetheless, further studies are still needed to confirm the identity and distinctiveness of these taxa.

The species of $S$. subg. S. sect. Schizolepis possess winged sheath, leaf-blades with pseudopremorse apex, and laciniate hypogynium. Within this section, S. arguta
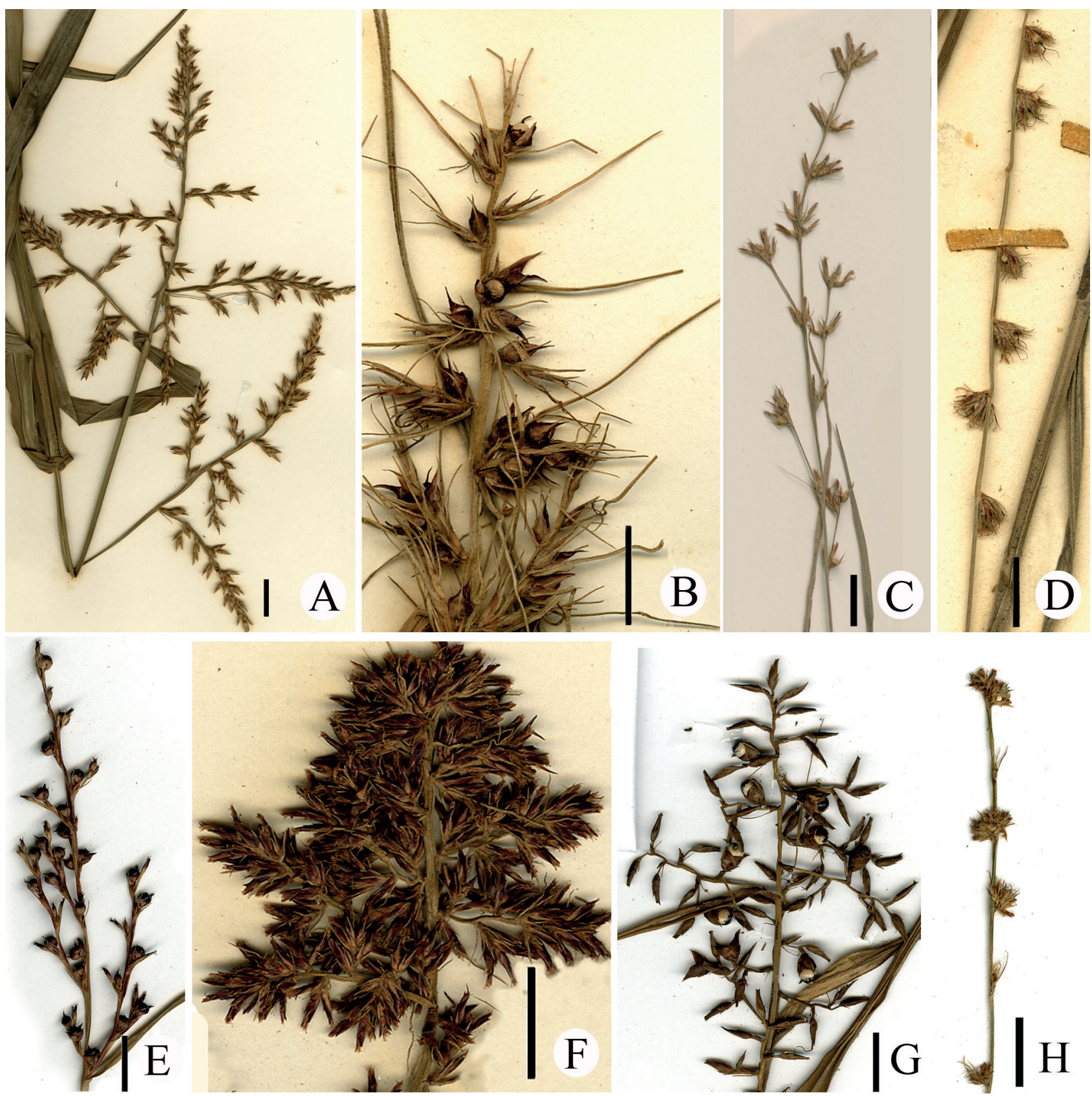

Figure 3. Inflorescences. A. Scleria arguta (Rosário, C.S. 406). B. S. bracteata, subandrogynous panicule (Oliveira, E. 6632). C. S. burchellii (Pinheiro, G.S. 546). D. S. distans (Cavalcante, P. 926). E. S. gaertneri (Schneider, L. 100). F. S. bracteata, staminate panicule (Oliveira, E. 6632). G. S. flagellum-nigrorum (Salomão, R.P. 1230). H. S. hirtella (Gil, A. 340). Scale 1 cm. Images: A-B, D-J Layla J.C. Schneider; C IAN Herbarium. 
can be compared with S. latifolia Sw. and S. plusiophylla Steud. (the latter, not found in the study area). Added to the characteristic features of the section, these three species also exhibit sparse inflorescences. Nevertheless, $S$. arguta can distinguished from S. latifolia and S. plusiophylla by its chartaceous leaf-sheaths (vs. papyraceous), patent inflorescence branches ( $v s$. patent to ascending), and nutlets ovoid with a crested-reticulate surface (vs. subglobose with smooth surface in S. latifolia; subglobose with tuberculate surface in S. plusiophylla).

Distribution and habitat: Bolivia and Brazil. In Brazil, it is recorded for the Northern (PA and RO), Central-Western (MT), and Southeastern ( $M G$ and RJ) regions. In the state of Pará, it known to occur at the edges of forests and savannas. This is the first record for the State of Pará.

\section{Scleria bracteata Cav., Icon. 5:34. 1799. \\ (Figs. 3B, F, 6C)}

Herbs $60-120 \mathrm{~cm}$ tall, perennial, monoecious, climbing, sometimes erect, solitary; rhizomes knotted. Stems 3-6.2 $\mathrm{mm}$ wide, glabrous to glabrescent, angles glabrous, unarmed. Leaf-sheaths $2.3-7 \mathrm{~cm}$ long, chartaceous, glabrescent to pubescent, unwinged, margins glabrous, unarmed; ligule only at the base of the leaf-blade, trichomes $0.3-0.7$ $\mathrm{mm}$ long, dense, golden. Contraligules 2.5-7 mm long, acute, apex ciliate, rarely armed, membranous appendage absent. Leaf-blades $14.1-37.5 \times 0.4-1.5 \mathrm{~cm}$, lanceolate, continuous to the sheath, abaxially glabrescent to pubescent, midrib armed, adaxially pubescent to glabrous with two armed ribs toward the apex, midrib puberulous, margins glabrous and armed, apex inconspicuously pseudopremorse. Involucral bracts $5-11.2 \times 0.1-0.9 \mathrm{~cm}$, linear to lanceolate, foliaceous. Inflorescences $30-53 \times 6.5-7 \mathrm{~cm}$, paniculate; rachis pubescent, angles ciliate, and/or armed. Spikelets staminate and subandrogynous, in distinct panicles.

Staminate spikelets 3-4.5 × 0.9-1.5 mm, ellipsoid, sessile or subsessile; pedicels up to $0.5 \mathrm{~mm}$ long. Subandrogynous spikelets $5-7 \times 1-2 \mathrm{~mm}$, lanceoloid to terete, sessile or subsessile; pedicels up to $0.3 \mathrm{~mm}$ long. Glumes stramineous to dark vinaceous and sometimes midrib green, glabrous to pubescent, midrib glabrous, unarmed or armed, margins glabrous to ciliolate, apex mucronate or mucronulate. Stamens 3 per flower. Nutlets $3-4 \times 2-3 \mathrm{~mm}$, globose, circular in cross-section, white to gray, surface crested, puberulous, base lacking pores, apex apiculate. Stylobase absent. Hypogynium developed, trilobed, lobes and apex lacerate, white to brown with dark margin, margin revolute. Cupules concave, trilobed, persisting at the rachilla, margin glabrous.

Selected material: BRAZIL. PARÁ: Acará, GuajaráMiri, ca. 14 km da PA-483, 1³0'36” S, 48²2'38.3” W, 28/ III/2018, fl. and fr., Schneider, L. \& Harley, R. 169 (MG); Almeirim, 1'30'27" S, 52 35'11" W, 25/IV/2015, fl. and fr., Rocha, A.E.S. \& Costa-Neto, S.V. 1978 (MG); Augusto
Corrêa, Ilha Rodrigues, terreno elevado com solo arenoso, circundado por manguezais aprox. $14 \mathrm{~km}$ ao leste de Augusto Corrêa, 3/VIII/2010, fl. and fr., Silva, M.J. 104 (HBRA); Barcarena, Várzea do Rio Tauá, margem esquerda, área do $5^{\circ}$ inventário, próximo aos lagos de rejeitos sólidos da ALBRAS, 134'22.5” S, 4846’02.3” W, 26/VI/1985, fl., Lins, A. et al. 324 (MG); Belém, Parque do Utinga, $1^{\circ} 25^{\prime} 08.8^{\prime \prime}$ S, 48 $26^{\prime} 19.0^{\prime \prime}$ W, 20/X/2015, fl. and fr., Maciel-Silva, J.F. et al. 38 (MG); Benevides, reserva da Pirelli, estrada do Taiassui com o ramal de entrada para Benevides, $1^{\circ} 20^{\prime} 51.4^{\prime \prime}$ S, 48¹5'32.2" W, 25/VII/1997, fl. and fr., Costa-Neto, S.V. et al. 93 (MG); Conceição do Araguaia, area of cerrado vegetation about $4 \mathrm{~km}$ west of town center along highway PA-150, 802'00" S, 5004'00" W, 21/II/1980, fl. and fr., Plowman, T. et al. 8973 (INPA, MG); Maracanã, campo da Mangaba, 046’07.8” S, 47³2'57.1” W, 18/XII/2009, fl., Rocha, A.E.S. 1167 (MG); Marapanim, 1,5km do tervo para Camará, 0³6'7" S, 4740'27" W, 6/VI/2017, fl. and fr., Schneider, L. et al. 133 (MG); Monte Alegre, Macau airstrip, 11/2 hrs. Upstream from Lageira airstrip, on Rio Maicuru, 055'00" S, 54²6’00" W, 24/VII/1981, fl., Strudwick, J.J. et al. 3458 (IAN, MG); Muaná, Porto Caiçara, ilha de mata em campo limpo, 1³1'36.1” S, 49¹3'03.9” W, 19/1/2005, fl., Silva, A.S.L. et al. 4262 (MG); Ourilândia do Norte, Colônia Nosso Campos, serra da Onça, 30/III/2003, fl. and fr., Rosário, C.S. \& Almeida, E. 2307 (MG); Ponta de Pedras, campo natural, 121'04" S, 4856'34" W, 18/XII/2003, fl. and fr., Silva, A.S.L. et al. 4118 (MG); Salvaterra, Joanes, 052'45” S, 48³0'38” W, 29/IX/2013, fl. and fr., Gurgel, E.S.C. et al. 971 (MG); Vigia, $17 \mathrm{~km}$ southeast of Vigia, along road (PA-140) to Belém, $0^{\circ} 57^{\prime} 00^{\prime \prime} \mathrm{S}, 48^{\circ} 05^{\prime} 00^{\prime \prime} \mathrm{W}$, 30/III/1980, fl. and fr., Davidse, G. et al. 17611 (MG); n.1., Estreito-Marabá, 4/IV/1974, fl. and fr., Pinheiro, G.S. 118 (IAN); Estreito-Marabá km 1, 4/IV/1974, fl. and fr., Pinheiro, G.S. 167 (IAN); Estreito-Marabá km 2, 4/IV/1974, fl. and fr., Pinheiro, G.S. 170 (IAN); Ilha do Marajó, capoeira de Condeixa, 15/XI/1948, fl. and fr. Black, G.A. 48-3586 (IAN).

Comment: Scleria bracteata is mainly characterized by its zonate inflorescences, subandrogynous basal panicles (Fig. 3B), and staminate distal panicles (Fig. 3F). Furthermore, some specimens may also present intermediate panicles with spikelets of both types. The staminate panicles are pyramidal. Frequently, the subandrogynous panicles exhibit few spikelets devoid of the pyramidal shape and exhibit filiform bracts that stand out visually in the panicle (Fig. 3B). Furthermore, the base of the leaf-blade is auriculated, the nutlets are globose and puberulous, and the hypogynium is trilobed with a shallow laciniate apex (i.e., lacerate) (Fig. 6C). Two specimens (Lins, A. et al. 324 - MG and Costa-Neto, S.V. et al. 93 - MG) presented galls on the fruits, developing horn-shaped structures which were laterally united to each other, and took the cupule's place or caused the fruit not to develop at all. Specimens found in the growing anthropized environments exhibited densely pubescent leaf-sheaths and blades, while specimens found growing 
in other environments exhibited glabrescent to sparsely pubescent leaf-sheaths and blades.

Distribution and habitat: Mexico, Belize, Guatemala, Honduras, Nicaragua, Panama, Trinidad and Tobago, French Guiana, Suriname, Guyana, Venezuela, Bolivia, Colombia, Ecuador, Peru, Brazil, and Paraguay. In Brazil, it is recorded for the Northern (AM, RR, AP, PA, and TO), Northeastern (MA, PI, CE, RN, PB, PE, AL, SE, and BA), Central-Western (MT, MS, GO, and DF), and Southeastern (MG, ES, RJ, and $\mathrm{SP})$ regions. In the state of Pará, it grows at clearings and forest edges, savannas, "várzeas", "capoeiras", "restingas", and anthropized environments.

4. Scleria burchellii C.B.Clarke, Kew Bull. Add. Ser. 8: 56. 1908.

(Figs. 3C, 6D)

Herbs $43-61.5 \mathrm{~cm}$ tall, annual, monoecious, erect, caespitose; rhizomes absent. Stem $1-1.5 \mathrm{~mm}$ wide, glabrous, angles glabrous, unarmed. Leaf-sheaths $5-6.1 \mathrm{~cm}$ long, membranous, glabrous or glabrescent, unwinged, margins glabrous or ciliate, unarmed; ligule absent. Contraligules truncate to concave, apex glabrous or ciliate, membranous appendage 1-1.5 mm long. Leaf-blade 19.5-27.1 × 0.2-0.3 $\mathrm{cm}$, linear, continuous to the sheath, abaxially glabrous, midrib glabrous to pubescent, adaxially glabrous, sometimes with two pubescent ribs, midrib glabrous, unarmed, margins glabrous, rarely ciliate, and armed or not, apex entire. Involucral bracts $0.5-2.5 \times \mathrm{ca} .0 .1 \mathrm{~cm}$, glumaceous or foliaceous, lanceolate. Inflorescences (5-)10.5-14.3 x $0.6-1.5 \mathrm{~cm}$, spiciform, unbranched, rarely branched; rachis glabrous, angles ciliate, and armed. Androgynous spikelets 4.5-5.5 $\times 0.9-1.5 \mathrm{~mm}$, terete, sessile or subsessile, pedicel up to $0.5 \mathrm{~mm}$ long. Glumes brown to reddish-brown with red lines and midrib green, glabrous, midrib glabrous, armed, margins glabrous, apex aristate. Stamens 2 per flower. Nutlets $1.6-1.9 \times 1.3-1.5 \mathrm{~mm}$, subglobose, subtriangular in cross-section, white, surface crested-reticulate with 3 smooth longitudinal bands, sometimes papillose, glabrous, base with 15-18 pores, apex apiculate. Stylobase absent. Hypogynium reduced, dark brown. Cupules flat, trilobed, persisting at the rachilla, margin glabrous.

Examined material: BRAZIL. PARÁ: n.l., EstreitoMarabá, km 2, 7/IV/1974, fl. and fr., Pinheiro, G.S. \& Carvalho J.F. 526 (IAN, UB); Estreito-Marabá, km 2, 7/IV/1974, fl. and fr., Pinheiro, G.S. \& Carvalho J.F 546 (IAN, UB); EstreitoMarabá, km 2, 7/IV/1974, fl. and fr., Pinheiro, G.S. \& Carvalho J.F. 558 (IAN, UB).

Comment: Scleria burchellii is characterized by its annual life-cycle, the contraligule presenting a membranous appendage, and a spiciform and rarely branched inflorescence, that when branched it is also surrounded by foliaceous bracts (Fig. 3C). Furthermore, the nutlet morphology is diagnostic, due to its crested-reticulate ornamentation with one smooth longitudinal band on each face (Fig. 6D), and base with two or three lines of pores, totaling 15-18 pores (Fig. 6D). The life-cycle, vegetative characters (i.e., such as the leaf-sheath and contraligule's membranous appendage), and coloration of the inflorescences and glumes of $S$. burchellii are similar to $S$. tenella Kunth. Nonetheless, S. tenella lacks a foliaceous involucral bract, even when the inflorescence is branched. Finally, Scleria burchellii possesses two stamens per flower (vs. one in S. tenella), larger spikelets (i.e., $4.5-5.5 \mathrm{~mm}$ long vs. 2.1-3.3 $\mathrm{mm}$ long in S. tenella), and crested-reticulate nutlets with smooth longitudinal bands (i.e., Fig. 6D vs. crested-reticulate to inconspicuously reticulate, sometimes papillose, lacking smooth longitudinal bands in S. tenella, Fig. 7K).

Distribution and habitat: Endemic to Brazil, being recorded for the Northern (PA), Central-Western (GO), and Southeastern $(M G)$ regions. This represents the first record for this species in the state of Pará. It was found growing in the savannas.

5. Scleria cyperina Willd. ex Kunth, Enum. Pl. 2: 345. 1837.

(Figs. 1B, 6E)

Herbs $49.6-76.3 \mathrm{~cm}$ tall, perennial, monoecious, erect or ascending, solitary; rhizomes knotted. Stem 1.5-9 mm wide, glabrous, angles glabrous, armed or not. Leaf-sheaths $2-12.3 \mathrm{~cm}$ long, chartaceous, glabrous to pubescent, basal ones unwinged, apical ones winged, wings 1.7-10.3 $\times 0.1-$ $0.2 \mathrm{~cm}$, margins glabrous, armed or not; ligule absent. Contraligules $0.3-9 \mathrm{~mm}$ long, acute, apex glabrescent to ciliate, sometimes armed, membranous appendage absent. Leaf-blades (8.3-)12.5-37 × 0.9-2.1 cm, linear, continuous to the sheath, abaxially glabrous, midrib armed, adaxially glabrous to puberulous with two armed ribs, midrib glabrous or glabrescent, margins glabrous and armed, apex entire. Involucral bracts $3.2-16.3 \times 0.2-1.2 \mathrm{~cm}$, foliaceous, lanceolate to narrow-elliptic. Inflorescences 3-9.1 $\times 2.2-7.5 \mathrm{~cm}$, paniculate; rachis glabrous, angles glabrous, and armed. Spikelets staminate and pistillate, in the same panicle. Staminate spikelets $3.5-4.8 \times 0.5-1$ $\mathrm{mm}$, lanceoloid to narrow-ellipsoid, pedicellate; pedicel 1.5-7(-9.5) $\mathrm{mm}$ long. Pistillate spikelets $4-7.5 \times 1-1.7$ $\mathrm{mm}$, lanceoloid to narrow-ellipsoid, sessile to pedicellate; pedicel up to $0.5(-3) \mathrm{mm}$ long. Glumes stramineous or with vinaceous margins, sometimes midrib green, glabrous or glabrescent, midrib glabrous, unarmed, margins glabrous or ciliolate, apex mucronate. Stamens 3 per flower. Nutlets 2.5-3.1 × 1.8-2.5 mm, ovoid, triangular in cross-section, white to reddish-brown, surface rugulose, puberulous, base lacking pores, apex apiculate or retuse. Stylobase absent. Hypogynium developed, trilobed, lobes triangular, light brown to brown, margin revolute, apex entire, sometimes laciniate. Cupules concave, trilobed, persisting at the rachilla, margin glabrous. 
Selected material: BRAZIL. PARÁ: [Alenquer], Sete varas airstrip on Rio Curuá, 54 60'32" W, 060'35” S, 4/ VIII/1991, fl., Strudwick, J.J. et al. 4053 (MG); Almeirim, Estação Ecológica do Jari, SEMA, 0²7’00” S, 5251'00” W, 9/IX/1987, fl., Pires, J.M. \& Silva, N.T. 1770 (MG); Cametá, Comunidade Humarizal, 29'14.5” S, 49³3'24.3” W, 3/ VI/2016, fl. and fr., Silva, C.A.S. \& Lara, S.N.F.F. 647 (MFS, MG); Canaã dos Carajás, S11-B, 6 $0^{\circ} 38^{\prime \prime}$ S, 50 25'22" W, 12/X/2008, Silva, L.V.C. et al. 606 (HCJS); Itaituba, Serra do Cachimbo, estrada de Santarém-Cuiabá, BR163, km 771, 22/IV/1983, fl. and fr., Silva, M.N. et al. 56 (MG, RB);

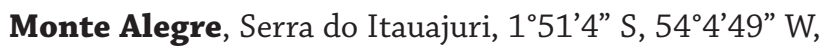
12/X/2016, fl., Giulietti, A.M. et al. 2670 (MG); Muaná, R. Gomes, margem esquerda, 6/III/1970, fl., Oliveira, E. 5171 (IAN); Óbidos, Estação Ecológica do Grão Pará, $0^{\circ} 38^{\prime} 33.7$ " S, 55 $41^{\prime} 47.5^{\prime \prime}$ W, 22/I/2009, fl. and fr., Souza, M.G.C. \& Teixeira, G. 462 (MG); Ponta de Pedras, Mangaba, $1^{\circ} 20^{\prime} 58^{\prime \prime}$ S, 4900'50" W, 20/II/2003, fl., Silva, A.S.L. \& Amaral, D.D. 4152 (MG); São Félix do Xingu, Serra dos Carajás, Serra dos Campos, SF1, 6²3'33" S, 51'54'2" W, 9/IV/2017, fl. and fr., Pastore, M. et al. 637 (MG); São Sebastião da Boa Vista, ca. $2 \mathrm{~km}$ from river Pracuuba-mirim. ca. 1 hour by boat upstream from São sebastião da boa vista, 15/X/1984, fl., Sobel, G.L. et al. 4579 (MG); n.l., Água Branca km 3, 28/ VII/1969, fl. and fr., Nilo T. Silva 2488 (IAN); Campos do Ariramba, margem do rio Jacumarú, 08/VI/1980, fl. and fr., Martinelli, G. 6910 (IAN, MG, RB); Ilha do Marajó, margem do Rio Maruarú, 4/X/1971, fl., Ribeiro, B.G.S. 179 (IAN); Rio Jamaracarú, Região do Ariramba, 27/V/1957, fl. and fr., Black, G.A. 57-19583 (IAN); Jaramacaru, 26/V/1957, fl., Cavalcante, P. 115 (MG).

Comment: Scleria cyperina is characterized by the absence of winged basal leaf-sheaths plus inconspicuously winged distal ones, absence of the contraligule's membranous appendage, pyramidal paniculate inflorescence with conspicuous foliaceous bracts at the base (Fig. 1B), trilobed hypogynium, corrugated as "smashed paper", with triangular lobes and entire apex, sometimes laciniate, and ovoid and puberulous nutlet (Fig. 6E). Scleria cyperina is among the species of $S$. subg. S. sect. Hymenolytrum, which can be distinguished easily by their inflorescence structure, with pistillate spikelets at the base of the branches and staminate spikelets at the apex. Scleria cyperina is similar to $S$. scabra Willd., S. martii (Nees) Steud., and S. violacea Pilg., distinguished mainly by its pyramidal inflorescence. However, it is clearly distinguished by the absence of the contraligule membranous appendage, which is present in the three aforementioned species.

Distribution and habitat: Honduras, French Guiana, Suriname, Guyana, Venezuela, Colombia, Peru, and Brazil. In Brazil, there are records to the North (AC, AM, RR, AP, $\mathrm{PA}, \mathrm{RO}$, and TO), Northeast (MA, PI, CE, RN, PB, PE, AL, $\mathrm{SE}$, and BA), Central-Western (MT, MS, GO, and DF) and Southeast (MG) regions. In the state of Pará, it occurs in forest edges and clearings, "campos rupestres", "capoeiras", "campinaranas", savannas, and anthropized environments.

6. Scleria distans Poir., Encycl. 7: 4. 1806.

(Figs. 3D, 6F)

Herbs $25.8-64 \mathrm{~cm}$ tall, perennial, monoecious, erect, solitary; rhizomes unknotted. Stems $0.8-1 \mathrm{~mm}$ wide, pubescent to glabrescent, angles ciliate, unarmed. Leaf-sheaths $2.9-4 \mathrm{~cm}$ long, papyraceous, pubescent or glabrescent, unwinged, margins ciliate and unarmed; ligule absent. Contraligules up to $1 \mathrm{~mm}$ long, truncate to acute, rarely trapeziform, apex ciliate, membranous appendage absent. Leaf-blades $6.5-24 \times 0.1-0.2 \mathrm{~cm}$, linear, continuous to the sheath, abaxially and midrib pubescent, adaxially glabrous, midrib pubescent, margins ciliate and armed toward the apex, apex entire. Involucral bracts $3.5-5$ $\times 0.05-0.1 \mathrm{~cm}$, glumaceous, lanceolate. Inflorescences 3.2-6.5(-10.4) × 0.7-1 cm, spiciform, unbranched; rachis glabrescent to pubescent, angles ciliate or not, and armed. Androgynous spikelets 3.1-4.5 × 0.9-1.3 mm, lanceoloid, sessile to pedicellate; pedicel up to $1 \mathrm{~mm}$ long. Glumes brown to reddish-brown and midrib green; glabrescent to pubescent, midrib pubescent and unarmed, margins glabrous, apex aristate. Stamens 2 per flower. Nutlets ca. $1.5 \times 0.9-1.2 \mathrm{~mm}$, subglobose, subtriangular in crosssection, white to gray, surface smooth, glabrous, base lacking pores, apex apiculate. Stylobase $0.3-1 \mathrm{~mm}$ long, terete, dark brown, persistent or deciduous. Hypogynium reduced, brown. Cupules flat, trilobed, persisting at the rachilla, margin glabrous.

Selected material: BRAZIL. PARÁ: Muaná, Rio Afuá, fazenda Berta, 21/IV/1962, fl. and fr., Dantas, M. \& Nivaldo S. 1010 (IAN); [Óbidos], Rio Parú do Oeste, Missão Tiriyos, Sede Missão, $2^{\circ} 20^{\prime} 00^{\prime \prime}$ S, $55^{\circ} 45^{\prime} 00^{\prime \prime}$ W, 12/II/1970, fl. and fr., Cavalcante, P. 2416 (MG); Salvaterra, Ilha do Marajó, Ig. Paixão, 4/IX/1969, fl. and fr., Oliveira, E. 4915 (IAN); Vigia, ca. 14 km ESE of Vigia; campina do São Benedito, $0^{\circ} 53^{\prime} 00^{\prime \prime}$ S, 4804'00" W, IV/1980, fl., Davidse, G. et al., 17749 (MG); n.l., Região dos Tiriós, Rio Paru do Oeste, 22/III/1962, fl. and fr., Dr. Fittkau \& Coelho, D. s.n. (INPA12860); Rio Tiriós, Parte Norte Ocidental do Estado do Pará, 12/V/1962, fl. and fr., Oliveira, E. 1856 (IAN); Ilha do Marajó, zona de influência do canal da hidrovia do Marajó. $32 \mathrm{~km}$ entre rios Anajás e Atuá, 8-18/I/1998, fl. and fr., Costa Neto, S.V. et al. 214 (MG); Ilha do Marajó, Rio Camará, III/1950, fl., Rubens Lima 43 (IAN).

Comment: Scleria distans is characterized by its conspicuous rhizome, pubescent leaves, spiciform inflorescence with reflexed fascicles (Fig. 3D), glumes with a pubescent midrib, nutlet subglobose, smooth and glabrous, lacking pores at the base, and the presence of a stylobase (Fig. 6F). It resembles the S. hirtella Sw. in its occasionally pubescent leaf-blades, and smooth nutlets. However, $S$. distans is perennial and rhizomatous ( $v s$. annual and rhizome 
absent in S. hirtella), and inflorescences with reflexed fascicles (vs. erect to ascending). These two species have a complicated history of identification, discussed by Robinson (1964) and Raynal (1976). Both authors emphasized that $S$. hirtella is annual, while $S$. distans is perennial (treated by both as $S$. nutans Willd. ex Kunth, which is currently a synonym of $S$. distans). The nutlet base of $S$. distans has been described presenting pores or not (Espinoza et al. 2016). Nonetheless, all specimens examined here lacked pores.

Distribution and habitat: Tropical and Subtropical America, Tropical and Subtropical Africa, and Madagascar. In Brazil, it is recorded for the Northern (AM, RR, PA, and TO), Northeastern (PI, CE, RN, PE, PB, AL, SE, and BA), Central-Western (MT, GO, DF, and MS), Southwestern (MG, ES, RJ, and SP), and Souther (PR, SC, and RS) regions. In the state of Pará, it occurs in "campinas" and savannas formations.

7. Scleria flagellum-nigrorum P.J.Bergius, Kongl. Vetensk. Acad. Handl.26: 144, pl. 4-5. 1765.

(Figs. 3G, 6G)

Herbs $0.7-3 \mathrm{~m}$ tall, perennial, monoecious, climbing, solitary; rhizomes not seen. Stems $3-4.5 \mathrm{~mm}$ wide, glabrescent to pubescent, angles glabrous, armed. Leafsheaths $3.5-8.5 \mathrm{~cm}$ long, chartaceous, pubescent to glabrescent, unwinged, margins glabrous, armed; ligule absent. Contraligules $1-2 \mathrm{~mm}$ long, rounded to acute, apex glabrous or ciliate, membranous appendage absent. Leafblades $20.6-30 \times 0.5-1 \mathrm{~cm}$, linear, continuous to the sheath, abaxially glabrescent, midrib conspicuously armed, adaxially glabrous or glabrescent, midrib pubescent, margins glabrous and armed, apex entire. Involucral bracts 7-26.1 × 0.4$0.8 \mathrm{~cm}$, foliaceous, linear to lanceolate. Inflorescences 23.5-31.5 × 4-5 cm, paniculate; rachis glabrescent, angles ciliate or not, and armed. Spikelets staminate and subandrogynous, in the same panicle. Staminate spikelets 5-5.5 × 1.3-1.9 mm, lanceoloid, subsessile to pedicellate; pedicel $0.5-4 \mathrm{~mm}$ long. Subandrogynous spikelets 3.3-5.6 × 1-2 mm, lanceoloid to narrow-ellipsoid, sessile to pedicellate; pedicel up to $2 \mathrm{~mm}$ long. Glumes brown to reddish-brown, sometimes with vinaceous maculae, glabrous, midrib glabrous, rarely armed, margins ciliolate, apex mucronate. Stamens 3 per flower. Nutlets $4-4.6$ $\times 2.8-3 \mathrm{~mm}$, subglobose, subcircular in cross-section, white with blackish maculae, surface smooth, glabrous or trichomes only near the hypogynium, base lacking pores, apex apiculate. Stylobase absent. Hypogynium developed, trilobed, lobes rounded, yellowish-brown, margin revolute, apex entire. Cupules concave, trilobed, persisting at the rachilla, margin glabrous.

Supplementary description: Rhizome present (Camelbeke et al. 2002).

Selected material: BRAZIL. PARÁ: Altamira, Belo Monte, rio Xingu, X-XII/2008, fl. and fr., Salomão, R.P. 1238
(MG); Capanema, Rio Quatipuru, in vicinity of Miraselvas, ca. $30 \mathrm{~km}$ by road west of Bragança, ca. $1^{\circ} 04^{\prime} 00^{\prime \prime} \mathrm{S}, 46^{\circ} 59^{\prime} 00^{\prime \prime}$ W, 09/IV/1980, fl. and fr., Davidse, G. et al. 18107 (MG); Santa Izabel, Carapurú, 25/IV/1977, fl. and fr., Silva, M.G. 3413 (MG); Santana do Araguaia, 110 km South of Redenção on road (PA - 150) to Barreiras dos Campos, approx. $8^{\circ} 45^{\prime} 00^{\prime \prime}$ S, $50^{\circ} 25^{\prime} 00^{\prime \prime} \mathrm{W}, 18 / \mathrm{II} / 1980$, fl. and fr., Plowman, T. et al. 8876 (INPA, MG); n.l., Alto Tapajós, Vila Nova, perto da Cachoeira do Chacorão, 24/I/1952, fl. and fr., Pires, J.M. 4026 (IAN); Alto Tapajós, Vila Nova, perto da Cachoeira do Chacorão, 19/I/1952, fl. and fr., Pires, J.M. 3961 (IAN); Estrada do Munguba, km 15, 13/VIII/1960, fl. and fr., Nilo T. Silva s.n. (IAN134486).

Comment: Scleria flagellum-nigrorum is a climbing herb (which climbs as it grows), devoid of winged leaf-sheaths, lacking both ligule and the contraligule's membranous appendage, with conspicuously armed leaf-blades margin, panicles with laxly-arranged spikelets (Fig. 3G), nutlets subglobose and smooth, and trilobed hypogynium (Fig. 6G). This species can be confused with $S$. secans due to its climbing habit, unwinged leaf-sheaths, and panicles with laxly-arranged spikelets. Nonetheless, S. flagellumnigrorum lacks a contraligule appendage ( $v s$. present in $S$. secans), presents staminate and subandrogynous spikelets (vs. staminate and pistillate in S. secans), and its trilobed hypogynium (Fig. 6G) (vs. annular in S. secans, Fig. 7G). Scleria flagellum-nigrorum was commonly misidentified as $S$. gaertneri Raddi in the consulted herbaria, probably due to its trilobed hypogynium with a revolute margin, and nutlets subglobose, white with dark maculae, and smooth surface. Nevertheless, S. flagellum-nigrorum has a climbing habit (vs. erect in S. gaertneri), chartaceous leaf-sheaths and blades (vs. papyraceous), and three stamens per flower (vs. one).

Distribution and habitat: Mexico, Costa Rica, Honduras, Guyana, Suriname, French Guiana, Venezuela, Bolivia, Colombia, Ecuador, Peru, and Brazil. In Brazil, it is recorded solely for the Northern region (AC, AM, RR, AP, $\mathrm{PA}$, and $\mathrm{RO}$ ). In the state of Pará, it occurs in forest edges and clearings, riparian forests, "várzeas", "capoeiras", and savannas.

8. Scleria gaertneri Raddi, Accad. Lucchese Sci., Lett. ed. Arti 2: 331. 1823.

(Figs. 3E, 6H)

Herbs 41.1-92 cm tall, perennial, monoecious, erect, caespitose or solitary; rhizomes knotted. Stems $1.5-4 \mathrm{~mm}$ wide, glabrescent to pubescent, angles glabrous, armed. Leaf-sheaths $3-9.5 \mathrm{~cm}$ long, papyraceous, glabrous to glabrescent, basal ones unwinged, apical ones winged, wings 1-6.4 × 0.05-0.1 cm, margins glabrous, armed; ligule absent. Contraligules $2-3.5 \mathrm{~mm}$ long, acute to rounded, apex ciliate, membranous appendage absent. Leaf-blades $21-45.1 \times 0.5-0.7 \mathrm{~cm}$, linear, continuous to the sheath, abaxially glabrous to glabrescent, midrib 
armed, adaxially glabrous to puberulous with two armed ribs, midrib puberulous, margins glabrous and armed toward the apex, apex entire. Involucral bracts $5-20.5 \times 0.2-0.8$ $\mathrm{cm}$, foliaceous, linear. Inflorescences 27-37.2 × 3-4 cm, paniculate; rachis glabrous to glabrescent, angles glabrous, and armed. Spikelets staminate and subandrogynous, in the same panicle. Staminate spikelets $3-4.2 \times 0.7-1.5$ $\mathrm{mm}$, lanceoloid to narrow-ellipsoid, pedicellate; pedicels $2.5-5 \mathrm{~mm}$ long. Subandrogynous spikelets $3.1-4.2 \times$ 0.7-1.6 mm, narrow-ellipsoid to lanceoloid, subsessile or pedicellate; pedicels $0.4-2.2 \mathrm{~mm}$ long. Glumes brown to reddish-brown with vinaceous maculae and midrib green, glabrous, midrib glabrous, armed, margins ciliolate, apex mucronate. Stamen 1 per flower. Nutlets 2.3-3.5 × 2-2.2 $\mathrm{mm}$, subglobose, circular in cross-section, white to gray, with vinaceous to dark maculae, surface smooth, glabrous or trichomes only near the hypogynium, base lacking pores, apex apiculate or rounded. Stylobase absent. Hypogynium developed, trilobed, lobes rounded, dark brown with margin light brown, margin revolute, apex entire. Cupules concave, trilobed, persisting at the rachilla, margin glabrous.

Select material: BRAZIL. PARÁ: Aveiro, Fordlândia, 5/I/1948, fl. and fr., Black, G.A. 48-2291 (IAN); Belém, Northeast woods of the I.A.N., 6/XI/1942, fl. and fr., Archer, W.A. 7782 (IAN); Benevides, Estrada do Mosqueiro/ DENPASA, 10/XI/1983, fl. and fr., Nivaldo, S. 48 (IAN); Cametá, Estrada Cametá-Limoeiro, 0159'31" S, 49²6'13" W, 5/VII/2017, fl. and fr., Fernandes-Júnior, A.J. et al. 610 (MG); Conceição do Araguaia, Range of low hills ca. 20 $\mathrm{km}$. West of Redenção, approx. $8^{\circ} 03^{\prime} 00^{\prime \prime} \mathrm{S}, 50^{\circ} 10^{\prime} 00^{\prime \prime} \mathrm{W}$, 8/II/1980, fl. and fr., Plowman, T. et al. 8500 (INPA, MG); Curuçá, Rio Cupari, 2/I/1948, fl. and fr., Black, G.A. 48-2243 (IAN); Igarapé-açú, Fazenda FCAP, capoeira do urucu, 16/I/1996, fl. and fr., Oliveira, F.P.M. et al. 22 (MG); Ipixuna do Pará, 28/X/2013, fl. and fr., Silva, C.A.S. 381 (MG); [Jacareacanga], Alto Tapajós, Rio Cururu, Florest and shrubby campo $S$ of Missão Cururú, at maloca duas Casas, $7^{\circ} 35^{\prime} 00^{\prime \prime}$ S, 57 31'00" W, 9/II/1974, fl. and fr., Anderson, W.R. 10706 (IAN, RB); Marabá, Floresta Rio Doce, 8/ VII/1987, fl., Lucinaldo Marinho 1356 (IAN); Melgaço, Floresta Nacional de Caxiuanã. Estação Científica Ferreira Penna. Sede da Estação Científica Ferreira Penna, $1^{\circ} 44^{\prime} 1^{\prime \prime}$ S, 51 27'19” W, 25/IV/2017, fl. and fr., Schneider, L. et al. 100 (MG); Monte Alegre, Iagarapé Jenipá, 21/I/1997, fl. and fr., Silva, J.B.F. et al. 827 (MG); Monte Dourado, Rio Jarí, 11/XII/1968, fl. and fr., Nilo T. Silva 1520 (IAN); Mosqueiro, Ariramba, 10/II/1952, fl. and fr., Ledoux, P. 67 (IAN); Ourém, 1 ${ }^{\circ} 32^{\prime} 49^{\prime \prime}$ S, 47 $06^{\prime} 47^{\prime \prime}$ W, IV/2012, fl. and fr., Lucas, F.C.A. \& Amaral, D.D. 68 (MFS); Oriximiná, Campo perto ao lago Chuaca, Terra Santa, $0^{\circ} 5^{\prime} 48^{\prime \prime}$ S, 55 22'09" W, 4/X/1984, fl. and fr., Irenice A. Rodrigues 1166 (IAN); Paragominas, Fazenda Agresta, 05/III/1980, fl. and fr., Vieira, I.C. 29 (MG); Parauapebas, Cedere1, estrada que dá acesso a Bocaina, 6¹4'44.85” S, 4954'34.06” W, 26/ IV/2012, Tyski, L. 274 (HCJS); Salinópolis, Cuiarana, transecto II., 20/IX/2013, fl. and fr., Gil, A. et al. 332 (MG); Salvaterra, Ilha do Marajó, Pousada dos Guarás, 22/VIII/14, fl. and fr., Gil, A. \& Cerqueira, R.M. 425 (MG); São Geraldo do Araguaia, Trilha da Casa de Pedra, rumo a cachoeira quarta queda, $06^{\circ} 09^{\prime} 48.8^{\prime \prime}$ S, 48 $38^{\circ} 19^{\prime \prime}$ W, 06/ VII/2018, Schneider, L. et al. 264 (MG); Tucuruí, ca. de 5km após o Breu Branco, Estrada que vai para Jaobal, 25/III/1981, fl. and fr., Silva, A.S.L. et al. 1450 (INPA, MG); Vitória do Xingu, $3^{\circ} 18^{\prime} 43^{\prime \prime}$ S, 51 47'52" W, 02/I/2015, fl. and fr., Alcantara, A. PSACF_EX04645 (RB); Viseu, Fernandes Belo, restinga da vila Apeú-Salvador, 055'23.3" S, 46¹2'18.6" W, 25/VI/2015, fl. and fr., Mehlig, U. 1702 (MG); n.1., Água Branca km 3, 28/VII/1969, fl. and fr., Nilo T. Silva 2520 (IAN); Ilha de Marajó, fazenda Menino Deus, 23/II/1950, fl. and fr., Black, G.A., 50-9027 (IAN); Ilha do Marajó, Zona de influência do canal da hidrovia do Marajó. $32 \mathrm{~km}$ entre os rios Anajás e Atuá, 8-18/I/1998, fl. and fr., Costa-Neto, S.V. et al. 290 (MG); Marajó, Rio Genipapo, retiro Ilha Nova, 27/IX/1965, fl. and fr, Oliveria, E. 3398 (IAN); Rio Ararí, Ilha do Marajó, Fazenda Tuiuiú, 4/V/1952, fl. and fr., Black, G.A. et al. 52-14422 (IAN); Rio Mojú, Fábrica, 1913, fl. and fr., Goeldi s.n. (IAN 96681).

Comment: Scleria gaertneri is characterized by its basal leaf-sheaths unwinged plus winged apical leaf-sheaths, inflorescence paniculate (Fig. 3E), nutlets subglobose, smooth, white to dark (Fig. 6H), and trilobed hypogynium with revolute margin (Fig. 6H). This species' nutlet can vary widely in color from white to purple and black, added to dark-colored macules, which can be present or not. The nutlet apex can be apiculate or rounded. Scleria gaertneri resembles $S$. flagellum-nigrorum in herbaria, with both species being commonly confused (see comment above).

Distribution and habitat: South Mexico to Tropical America, Tropical Africa, and Madagascar. It is recorded for all Brazilian States. In the state of Pará, it occurs in forest borders, "campinaranas", "campos rupestres", "restingas", savannas, "várzeas", and anthropized environments.

9. Scleria hirtella Sw., Prodr. 19. 1788.

(Figs. 3H, 6I)

Herbs $22-49 \mathrm{~cm}$ tall, annual, monoecious, erect, caespitose or solitary; rhizomes absent. Stems $0.6-1 \mathrm{~mm}$ wide, glabrous to pilose, angles glabrous to ciliate, and unarmed. Leaf-sheaths $2-4.5 \mathrm{~cm}$ long, membranous, glabrous to pilose, unwinged, margins glabrous or ciliate, unarmed; ligule absent. Contraligules up to $0.6 \mathrm{~mm}$ long, truncate to acute, apex ciliate, membranous appendage $0.1-0.8 \mathrm{~mm}$ long. Leaf-blades $7.2-21 \times 0.1-0.2 \mathrm{~cm}$, linear, continuous to the sheath, abaxially glabrous to pubescent, midrib pubescent and armed toward the apex, adaxially glabrous to pubescent, midrib glabrous, unarmed, margins glabrous to ciliolate and armed toward the apex, apex entire. Involucral bracts $3-6 \times 0.03-0.1 \mathrm{~cm}$, glumaceous, lanceolate. Inflorescences $3.5-9 \times 0.8-1 \mathrm{~cm}$, spiciform, 
unbranched; rachis glabrous to glabrescent, angles glabrous, and unarmed. Androgynous spikelets $2.8-3.3 \times 0.6-1$ $\mathrm{mm}$, terete, sessile to subsessile; pedicels up to $0.4 \mathrm{~mm}$ long. Glumes brown to reddish-brown and midrib green, glabrescent, midrib pubescent or pilose, unarmed, margins glabrous, apex aristate. Stamens 2 per flower. Nutlets 1.1-1.9 × 1-1.2 mm, globose, circular in cross-section, white to gray, surface smooth, glabrous, base with 9-12 pores, apex apiculate. Stylobase absent. Hypogynium reduced, brown. Cupules flat, trilobed, persisting at the rachilla, margin glabrous.

Selected material: BRAZIL. PARÁ: Bragança, Península de Ajuruteua, 050'11" S, 46³7'09” W, 22/ VI/2008, fl. and fr., Oliveira, E.S. 50 (INPA); Cachoeira do Arari, Rodovia km 14, 054'30.4" S, 4840’5.8” W, 20/ IX/2017, fl. and fr., Schneider, L. \& Silva, F.A. 152 (MG); Salvaterra, Praia do Salazar, Ilha do Marajó, $0^{\circ} 47^{\prime 2} 23^{\prime \prime}$ S, 48 31'14" W, 18/IX/2014, fl. and fr., Falcão da Silva, M. et al. 550 (MG); Salinópolis, Cuiarana, próximo ao PIII do projeto Itarana/MPEG, 20/IX/2013, fl. and fr., Gil, A. et al. 340 (MG); São Caetano de Odivelas, Ilha de Itaquari, 25/ VIII/1998, fl. and fr., Bastos, M.N. et al. 1909 (MG); n.1., Rio Camará, pau grande, fazenda Santa Rita, 8/VII/1950, fl. and fr., Black, G.A. 50-9988 (IAN); Rio Camará, Ilha do Marajó, Fazenda Gurupatuba, 8/VII/1950, fl. and fr., Black, G.A. 50-9922 (IAN); Rio Camará, Ilha do Marajó, Fazenda Gurupatuba, 8/VII/1950, fl. and fr., Black, G.A. 50-9903 (IAN); Rio Mojú, campina da Fábrica, 4/VI/1954, fl. and fr., Black, G.A. 54-16341 (IAN); Marajó, Rio Camará, terrenos altos entre arroz do campo, IX/1902, fl. and fr., Miranda, V.C. 3092 (IAN, INPA, MG).

Comment: Scleria hirtella is an annual species, with glabrous to pubescent stems and leaves, spiciform inflorescences (Fig. $3 \mathrm{H}$ ), glumes with pubescent or pilose midribs, and smooth nutlet with pores at the base (Fig. 6I). It is similar to $S$. distans (see the comment for $S$. distans) and $S$. interrupta Rich., due to its occasionally pubescent stems and leaf-blades, and unbrunched spiciform inflorescences. Scleria hirtella and $S$. interrupta are annuals herbs with spiciform inflorescence, ascending to erect fascicles, and can also present pubescent vegetative organs. The ornamentation of the nutlet is diagnostic between these species (Robinson 1964; Raynal 1976; Bauters et al. 2019), being smooth in S. hirtella and ornate in S. interrupta. Despite this remarkable difference, Raynal (1976) commented that some specimens of $S$. hirtella present a little ornate nutlet with some papilla. However, these specimens with a slightly ornamented nutlet are being treated here as $S$. interrupta, because we consider $S$. hirtella to be only those specimens with smooth nutlets, as observed in its nomenclatural type (Swartz s.n., B-W1733001).

Distribution and habitat: Tropical and Subtropical America. In Brazil, it is recorded for all regions and most States, namely, Northern (AM, RR, PA, and TO), Northeastern (PI, CE, RN, PE, PB, AL, SE, and BA), Central-
Western (MT, GO, DF, and MS), Southeastern (MG, ES, RJ, and SP), and Southern (PR, SC, and RS). In the state of Pará, it is found growing in savannas and "restingas".

10. Scleria interrupta Rich., Actes Soc. Hist. Nat. Paris 1: 113. 1792.

(Figs. 4A, 6J)

Herbs $44-52 \mathrm{~cm}$ tall, annual, monoecious, erect, caespitose; rhizomes absent. Stems ca. $1 \mathrm{~mm}$ wide, pubescent to pilose, angles ciliate, unarmed. Leaf-sheaths $3.4-5.5 \mathrm{~cm}$ long, membranous, pubescent to pilose, unwinged, margins ciliate, unarmed; ligule absent. Contraligules up to $1 \mathrm{~mm}$ long, truncate to acute, apex ciliate, membranous appendage ca. $0.5 \mathrm{~mm}$ long. Leaf-blades $5.2-19.8 \times$ ca. $0.1 \mathrm{~cm}$, linear, continuous to the sheath, abaxially glabrescent to pilose, midrib pubescent to pilose, adaxially pilose to glabrous, midrib glabrous, unarmed, margins ciliate and armed toward the apex, apex entire. Involucral bracts $3.1-5 \times$ $0.5-1 \mathrm{~cm}$, glumaceous, lanceolate. Inflorescences $3.4-7.3 \times$ $0.6-1 \mathrm{~cm}$, spiciform, unbranched; rachis glabrescent, angles glabrous, and unarmed. Androgynous spikelets 2.9-3.5 $\times 0.6-1 \mathrm{~mm}$, lanceoloid, subsessile; pedicel ca. $0.3 \mathrm{~mm}$ long. Glumes brown to reddish-brown and midrib green, glabrescent, midrib pilose, unarmed, margins glabrous, apex mucronate to aristate. Stamens 2 per flower. Nutlets $1.3-1.7 \times 1-1.3 \mathrm{~mm}$, globose, subcircular in cross-section, white, surface crested and papillose, sometimes slightly papillose, glabrous, base with $9-12$ pores, apex apiculate. Stylobase absent. Hypogynium reduced, brown. Cupules flat, trilobed, persisting at the rachilla, margin glabrous.

Selected material: BRAZIL. PARÁ: Augusto Corrêa, Ilha do Rodrigues, aprox. $14 \mathrm{~km}$ ao leste de Augusto Corrêa, $1^{\circ} 01^{\prime} 44^{\prime \prime}$ S, 46 30'55" W, 21/VII/2010, fl. and fr., Silva, M.J. et al. 40 (HBRA); Bragança, Peninsula de Ajuruteua, 0 50'10" S, 46 37'17" W, 5/VI/2007, fl. and fr., Santos, L.O. et al. 346 (HBRA, MG); Marapanim, Vila de Marudá, Praia do Crispim, 15/VI/1991, fl. and fr., Bastos, M.N. et al. 972 (MG); Monte Alegre, Serra do Itauajuri, 151'9" S, 54 4'47" W, 22/VII/2018, fl. and fr., Zappi, D. et al. 4338 (MG); São João de Pirabas, Praia do Buraco, 041'18.6” S, 4606'19.1' W, 15/V/2011, fl. and fr., Mehlig, U. et al. 1016 (HBRA).

Comment: Scleria interrupta is an annual species, which exhibits glabrous to pubescent stems and leaves, inflorescence with ascending to erect fascicles (Fig. 4A), glumes with pubescent midribs, and a crested and papillose nutlet. Among the species of Scleria subg. H. sect. Hypoporum treated here, S. hirtella, S. interrupta, and S. tenella can be confused with each other. Scleria hirtella and S. interrupta exhibit glabrous to pubescent leaves, while $S$. tenella exhibits glabrous leaves. Scleria hirtella presents smooth nutlets (Fig. 6I), while S. interrupta and S. tenella present crested to papillose or crested-reticulate nutlets, respectively (Figs. $6 \mathrm{~J}, 7 \mathrm{~K}$; see the comment for $S$. hirtella). Nonetheless, some specimens might present characteristics shared between 
S. interrupta and S. tenella. After analyzing the original descriptions, types, and other specimens, we noticed that the midrib of the basal glume in S. interrupta (which encloses the pistillate flower) has some soft and long trichomes, while the staminate flowers present two stamens. Alternatively, in S. tenella, the midrib of the basal glume presents some rigid and short trichomes toward the apex, while the staminate flowers have a sole stamen.

Distribution and habitat: Southeast Mexico to Tropical America. In Brazil, it is recorded for the Northern (PA), Northeastern (CE, RN, PE, PB, AL, SE, and BA), Central-Western (MT), and Southeastern (MG) reagions. In the state of Pará, it occurs in the restingas.

11. Scleria lacustris C.Wright, Anales Acad. Ci. Med. Habana 8: 152. 1871.

(Figs. 4B, 6K)

Herbs $0.7-1 \mathrm{~m}$ tall, annual, monoecious, erect to climbing, solitary; rhizomes absent. Stems $3.5-5 \mathrm{~mm}$ wide, glabrous, angles glabrous, armed. Leaf-sheaths 6.1-10.5 $\mathrm{cm}$ long, chartaceous, glabrous, unwinged, margins glabrous and unarmed or armed; ligule absent. Contraligules 3-4 $\mathrm{mm}$ long, acute to rounded, apex glabrous, membranous appendage ca. $2 \mathrm{~mm}$ long. Leaf-blades 20.6-32.7 × 1-1.4 $\mathrm{cm}$, linear, continuous to the sheath, abaxially glabrous, midrib armed toward the apex, adaxially glabrous with two armed ribs, midrib glabrous, unarmed, margins glabrous and armed, apex entire. Involucral bracts 13.4-26.1 × $0.2-0.8 \mathrm{~cm}$, foliaceous, linear. Inflorescences $38.5-52.8$ $\times 6-29 \mathrm{~cm}$, paniculate; rachis glabrous, angles glabrous, and armed. Spikelets staminate and subandrogynous, in the same panicle. Staminate spikelets $3.2-4.7 \times 1-1.5$ $\mathrm{mm}$, terete to lanceoloid, pedicellate; pedicel 1.2-1.5 $\mathrm{mm}$ long. Subandrogynous spikelets $4-4.3 \times 1.2-1.9 \mathrm{~mm}$, narrow-ellipsoid to lanceoloid, subsessile or pedicellate; pedicel 0.5-1.4 mm long. Glumes reddish-brown with dark margins, glabrous, midrib glabrous, armed, margins ciliolate, apex mucronate. Stamens 3 per flower. Nutlets 3-3.5 × 2-2.3 mm, ovoid to ellipsoid, subcircular in cross-section, white to yellowish-brown, sometimes with dark maculae, surface smooth, glabrous, base lacking pores, apex obtuse. Stylobase absent. Hypogynium developed, zoniform, lobes inconspicuously rounded, yellowish-brown, margin

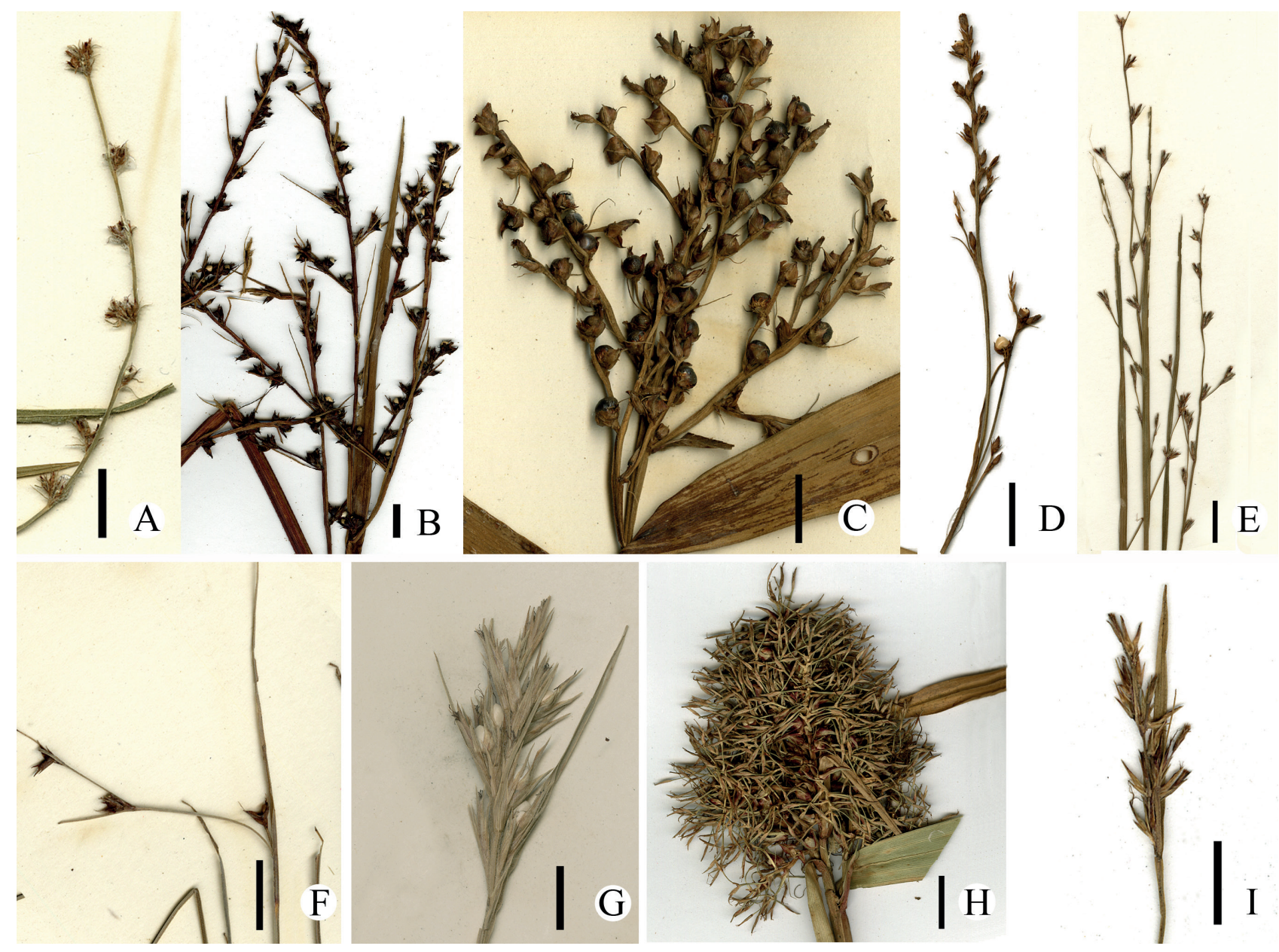

Figure 4. Inflorescences. A. Scleria interrupta (Santos, L.O. 346). B. S. lacustris (Lobato, L.C.B. 3218). C. S. latifolia (Silva, A.S. 48). D. S. microcarpa (Silva, A.S.L. 4131). E. S. pusilla (Plowman, T. 8664). F. S. lithosperma (Plowman, T. 8980). G. S. longigluma (Pena, B.S. 216). H. S. martii (Rosário, C.S. 2340). I. S. reticularis (Schneider, L. 127). Scale 1 cm. Images: A-F, H-I Layla J.C. Schneider; G. IAN Herbarium. 
flat, apex entire. Cupules concave, trilobed, persisting at the rachilla, margin glabrous.

Selected material: BRAZIL. PARÁ: Almeirim, Jacarenim, caminho para a Serra de Almeirim, 29/III/1963, fl. and fr., Oliveira, E. 2411 (IAN); Óbidos, Igarapé das Fazendas, Cruzeiro, Lago Grande, 20'0” S, 55³0'00" W, 7/V/1984, fl. and fr., Iranice A. Rodrigues 1081 (IAN); Oriximiná, NW-corner of lago Sapucuá, 23/II/1988, fl. and fr., Kubtitzki, K. 88-13 (MG); Monte Alegre, Lago grande, V/1996, fl. and fr., Projeto IARA s.n. (IAN170072); n.1., Cacaual grande, Canal do Piapó, 6/VII/1952, fl. and fr., Black, G.A. 52-15476 (IAN); Rio Amazonas, vegetação flutuante dos campos de várzea entre Alenquer e Rio Curuá, $1^{\circ} 55^{\prime} 00^{\prime \prime} \mathrm{S}$, between $54^{\circ} 50^{\prime} 0^{\prime \prime} \mathrm{W}$ and $55^{\circ} 10^{\prime} 00^{\prime \prime} \mathrm{W}, 05-06 /$ VI/1981, fl. and fr., Jangoux, J. \& Ribeiro, B.G.S. 1586 (MG).

Comment: Scleria lacustris occurs in aquatics environments. It has conspicuously armed stems and leaf-blades margins, paniculate inflorescence with congest spikelets in fascicles (Fig. 4B), zoniform hypogynium (Fig. $6 \mathrm{~K}$ ), and ovoid, smooth and glabrous nutlets (Fig. 6K) with three horizontal incisions at the base (Fig. 6K). This species presents congested fascicles that resemble the inflorescence type found in Scleria subg. Hypoporum. Additionally, it presents an inconspicuous hypogynium, plus occasional androgynous spikelets (Lobato, L.C.B. $3218-\mathrm{MG}$ ), which are also characteristic of this subgenus. Nelmes (1955) placed this species into the $S$. sect. Hypoporum due to the presence of occasional androgynous spikelets. Nonetheless, the author also pointed out that S. lacustris also shares characters with other sections, such as armed stem and leaves, and an evident contraligule. Ahumada \& Vegetti (2009) commented on the inflorescence architecture and inconspicuous hypogynium of $S$. lacustris and placed it into S. sect. Scleria. Nonetheless, these authors emphasized that further studies should be done to accurately define the section in which this species should be placed. Posteriorly, a phylogenetic study based on molecular data elucidated the placement of $S$. lacustris, undoubtedly placing it $S$. subg. Scleria sect. Margaleia, which includes aquatic species with zoniform hypogynium (Bauters et al. 2016).

Distribution and habitat: Belize, Costa Rica, Cuba, Guyana, Suriname, French Guiana, Venezuela, Bolivia, Brazil, Paraguay, Tropical Africa, and Madagascar. In Brazil, it is recorded for the Northern (AM, RR, and PA) and Northeastern (MA) regions. In the state of Pará, it can be found growing in riparian forests, "várzeas", and "igapós".

12. Scleria latifolia Sw., Prodr. 18. 1788.

(Figs. 4C, 6L)

Herbs $0.4-1.5 \mathrm{~m}$ tall, perennial, monoecious, erect, solitary; rhizomes unknotted. Stems $0.3-1 \mathrm{~cm}$ wide, glabrous to puberulous, angles glabrous, unarmed or armed. Leaf-sheaths $2.8-11.3 \mathrm{~cm}$ long, papyraceous, glabrous to puberulous, winged, wings $3-7 \times 0.5-0.6 \mathrm{~cm}$, margins glabrous and armed; ligule absent. Contraligules $5-8 \mathrm{~mm}$ long, acute to rounded, apex glabrous or ciliate, membranous appendage absent. Leaf-blades $21-45.5 \times 2.5-4.8 \mathrm{~cm}$, linear to oblong, continuous to the wings of the sheaths, abaxially glabrous to glabrescent, midrib armed toward the apex, adaxially glabrous with two armed ribs, midrib armed toward the apex, margins glabrous and armed, apex pseudopremorse. Involucral bracts $6.3-31.5 \times 0.8-4.2$ $\mathrm{cm}$, foliaceous, narrow-elliptic to oblong. Inflorescences $18-22.5 \times 5.7-10 \mathrm{~cm}$, paniculate; rachis puberulous, angles glabrous, and armed. Spikelets staminate and subandrogynous, in the same panicle. Staminate spikelets 2.8-4 × 1-1.5 mm, terete to lanceoloid, pedicellate; pedicel $1-4(-6) \mathrm{mm}$ long. Subandrogynous spikelets $3.5-5 \times$ 1.2-2.3 mm, narrow-ellipsoid to lanceoloid, subsessile or pedicellate; pedicel $0.5-1.4 \mathrm{~mm}$ long. Glumes brown to reddish-brown, puberulous, midrib glabrous, armed, margins ciliolate, apex mucronate or mucronulate. Stamens 3 per flower. Nutlet $1.5-2 \times 2.5-3.5 \mathrm{~mm}$, subglobose, subcircular in cross-section, white with purple maculae to dark, surface smooth, glabrous, base lacking pores, apex rounded. Stylobase absent. Hypogynium developed, trilobed, lobes and apex laciniate, totally brown or brown with reddish apex, margin flat. Cupules concave, trilobed, persisting at the rachilla, margin glabrous.

Selected material: BRAZIL. PARÁ: Bragança, Colônia Benjamin Constant, 16/XI/1908, fl. and fr., Pessoal do Museu 9772 (INPA, MG); Canaã dos Carajás, Floresta Nacional de Carajás, Serra Sul-S11D, 6²2’41" S, 50²1’26” W, 3/ XII/2015, fl. and fr., Nunes, C.S. et al. 92 (MG); [Cumaru do Norte], Gorotire, 28/VIII/1985, fl., Anne Gély 533 (MG); Marabá, Serra dos Carajás, $6^{\circ} 00^{\prime} 00^{\prime \prime}$ S, 50¹5’00” W, 15/X/1977, fl. and fr., Berg, C.C. 547 (INPA); Parauapebas, Floresta Nacional de Carajás, acampamento Águas Claras, trilha Peito de Aço, 6/XII/2017, fl. and fr., Schneider, L. et al. 164 (MG); Santarém, Margem direita do Rio Ruauna, Reserva Florestal do Curuauna, Barreirinha, 26/VIII/1988, fl. and fr., Rosário, C.S. 1030 (MG).

Comment: Scleria latifolia presents winged leaf-sheaths, leaf-blades that are continuous to the wing sheath, with a pseudopremorse apex, paniculate inflorescences (Fig. 4C), brown laciniate hypogynium, with the laciniae sometimes reddish apex, resembling flames, and subglobose, smooth and glabrous nutlets (Fig. 6L). It is similar to S. arguta, which also occurs in the state of Pará (see the comment for S. arguta). Scleria latifolia also resembles S. plusiophylla, especially when not in fruit. Nonetheless, S. plusiophylla does not occur in the study area. Both species can be differentiated by their leaf-blades, which are glabrous to glabrescent in S. latifolia and pubescent in S. plusiophylla. Furthermore, when present, nutlets are diagnostic being smooth in S. latifolia and rugose in S. plusiophylla.

Distribution and habitat: Southwestern and southeastern Mexico, Belize, Costa Rica, Guatemala, Honduras, Nicaragua, Panama, Jamaica, Trinidad and 
Tobago, Guyana, Suriname, French Guiana, Venezuela, Bolivia, Colombia, Ecuador, Peru, Brazil, Argentina, and Paraguay. In Brazil, it is recorded for the Northern (AC, AM, RR, PA, and TO), Northeastern (MA, PI, CE, RN, PE, PB, $\mathrm{AL}, \mathrm{SE}$, and $\mathrm{BA}$ ), Central-Western (MT, GO, DF, and MS), Southeastern (MG, ES, RJ, and SP), and Southern (PR, SC, and RS) regions. In the of state of Pará, it grows in forest edges and clearings.

13. Scleria lithosperma (L.) Sw., Prodr. 18.1788. 三Schoenus lithospermus L., Sp. Pl. 1: 51. 1753.

(Figs. 4F, 6M)

Herbs ca. $40 \mathrm{~cm}$ tall, perennial, monoecious, erect, solitary; rhizomes unknotted. Stems ca. $1 \mathrm{~mm}$ wide, glabrous, angles glabrous, armed. Leaf-sheaths ca. $3 \mathrm{~cm}$ long, papyraceous, glabrous to puberulous, unwinged, margins ciliate, unarmed; ligule absent. Contraligules ca. $1 \mathrm{~mm}$ long, acute, apex ciliate, membranous appendage absent. Leaf-blades $3.4-16.1 \times 0.2-0.3 \mathrm{~cm}$, linear, continuous to the sheath, abaxially glabrous, midrib armed toward the apex, adaxially glabrous with two armed ribs, midrib glabrous, unarmed, margins glabrous and armed toward the apex, apex entire. Involucral bracts 1-2.5($4.5) \times \mathrm{ca} .0 .1 \mathrm{~cm}$, foliaceous, lanceolate. Inflorescences 4-6.3 $\times 0.6-1.2 \mathrm{~cm}$, paniculate; rachis glabrescent, angles glabrous, and armed. Spikelets androgynous $4-5.1 \times$ ca. $1 \mathrm{~mm}$, terete to lanceoloid, pedicellate; pedicel 1-2 $\mathrm{mm}$ long. Glumes reddish-brown with red lines, glabrous, midrib glabrous, armed, margins glabrous to ciliolate, apex mucronate. Stamen 1 per flower. Nutlet ca. $2.5 \times 1.5 \mathrm{~mm}$, ellipsoid, subtriangular in cross-section, grayish-white, surface smooth, glabrous, base lacking pores, apex rounded. Stylobase absent. Hypogynium reduced, black. Cupules flat, trilobed, persisting at the rachilla, margin glabrous.

Examined material: BRAZIL. PARÁ: Conceição do Araguaia, Redenção, área of cerrado vegetation about 4 $\mathrm{km}$. West of town center along highway PA-150, $8^{\circ} 02^{\prime} 00^{\prime \prime}$ S, 5004'00" W, 21/II/1980, fl. and fr., Plowman, T. et al. 8980 (MG).

Comment: Scleria lithosperma is a rhizomatous species, with foliaceous involucral bracts, poorly branched paniculate inflorescences (Fig. 4F), a few spikelets per fascicle (i.e., 1-3), smooth, glabrous and ellipsoid nutlets, and reduced black hypogynium (Fig. 6M). This species compounds the monotypic $S$. subg. Hypoporum sect. Lithospermae distinguinshed by the poorly paniculate inflorescence, wich is speciform in $S$. subg. H. sect. Hypoporum and virgately branched in $S$. subg. $H$. sect. Virgatae Bauters (Bauters et al. 2018). In some of the visited herbaria, we noticed some specimens identified as $S$. lithosperma. Nonetheless, these specimens presented spiciform inflorescences and glumaceous bracts but lacked nutlets. They actually represent S. leptostachya Kunth (S. subg. H. sect. Hypoporum), which is not recorded for our study area. Aside from the involucral bract and inflorescence (foliaceous and paniculate in S. lithosperma vs. spiciform and glumaceous in S. leptostachya), the nutlets are also diagnostic. In S. lithosperma, the nutlet is ellipsoid and lacks basal pores, while in S. leptostachya, it is subglobose with basal pores.

Distribution and habitat: Tropics and Subtropics. In Brazil, it is recorded for the Northern (PA and TO) and Central-Western (GO) regions. In the state of Pará, where it occurs in savannas.

14. Scleria longigluma Kük., Bot. Jahrb. Syst. 56 (Beibl. 125): 22. 1921.

(Figs. 4G, 6N)

Herbs ca. $70 \mathrm{~cm}$ tall, perennial, monoecious, erect, solitary; rhizomes unknotted. Stems 2-3 mm wide, glabrous, angles glabrous, armed. Leaf-sheaths 10-11.5 cm long, membranous, glabrous, unwinged, margins ciliate, unarmed; ligule absent. Contraligules 2-4 mm long, trapeziform, apex glabrous, membranous appendage absent. Leaf-blades $11.8-41 \times 0.9-1 \mathrm{~cm}$, linear, continuous to the sheath, abaxially glabrescent, midrib ciliate, adaxially glabrescent with two pilose ribs, midrib glabrous, unarmed, margins ciliate and unarmed, apex entire. Involucral bracts $7.3-14.2 \times 0.5-0.9 \mathrm{~cm}$, foliaceous, lanceolate. Inflorescences $9-24 \times 2-2.5 \mathrm{~cm}$, paniculate; rachis glabrescent to pilose, angles ciliate, and unarmed. Spikelets staminate and subandrogynous, in the same panicle. Staminate spikelets $1-1.3 \times 0.2-0.3 \mathrm{~cm}$, terete to narrow-ellipsoid, sessile to pedicellate; pedicel up to $2.5 \mathrm{~mm}$ long. Subandrogynous spikelets $\mathrm{ca} .1 .5 \times 0.2$ $\mathrm{cm}$, narrow-ellipsoid, sessile. Glumes yellowish-brown with midrib green, glabrous, midrib pilose, armed, margins glabrous or ciliolate, apex mucronate or apiculate. Stamens 2 per flower. Nutlets $5.3-5.5 \times$ ca. $3 \mathrm{~mm}$, ovoid to oblong, subtriangular in cross-section, white to yellowish-brown, surface smooth or rugulose, glabrous, base lacking pores, apex obtuse. Stylobase absent. Hypogynium developed, zoniform, lobes rounded inconspicuous, yellowish-brown to dark, margin flat, apex entire. Cupules concave, trilobed, persisting at the rachilla, margin glabrous.

Examined material: BRAZIL. PARÁ: Muaná, llha do Marajó, próximo a fazenda do Espírito Santo, 23/X/1970, fl. and fr., Pena, B.S. 216 (IAN).

Comment: Scleria longigluma is distinguished by its ciliate leaf-blades, paniculate inflorescences with congested spikelets (Fig. 4G), ovoid to oblong, smooth to rugulose nutlets (Fig. 6N), and zoniform hypogynium (Fig. 6N). It differs further from the other species in the study area due to the length of its spikelets (i.e., $1-1.5 \mathrm{~cm}$ long $v$ s. shorter than $1 \mathrm{~cm}$ long).

Distribution and habitat: Guyana, Suriname, French Guiana, Venezuela, Colombia, Brazil, Argentina, and Paraguay. In Brazil, it is recorded for the Northern (AM, RR, PA, and TO), Northeastern (MA), and Central-Western 
(MT and GO) regions. In the state of Pará, it is found growing in savannas. It is the first record for the state of Pará.

15. Scleria macrophylla J.Presl \& C.Presl, Reliq. Haenk. 1(3): 200. 1828.

(Figs. 1C, 60)

Herbs $0.6-1.7 \mathrm{~m}$ tall, perennial, monoecious, erect, solitary; rhizomes unknotted. Stems $0.4-1 \mathrm{~cm}$ wide, glabrous, angles glabrous, armed or not. Leaf-sheaths 3.2-14.6 cm long, chartaceous, glabrescent to puberulous, winged, wings $3-14.2 \times 0.2-0.7 \mathrm{~cm}$, margins glabrous, armed; ligule absent. Contraligules 2-7 $\mathrm{mm}$ long, acute, apex glabrous, membranous appendage absent. Leaf-blades $24.9-54.3 \times 3.5-5.6 \mathrm{~cm}$, linear to lanceolate, continuous to the wings of the sheaths, abaxially glabrous, midrib armed, adaxially glabrous to puberulous toward the apex, midrib glabrous, unarmed, margins glabrous and armed, apex pseudopremorse. Involucral bracts $8.1-40 \times 1-3.1$ $\mathrm{cm}$, foliaceous, linear to lanceolate. Inflorescences $32-51$ $\times 5.5-10.5 \mathrm{~cm}$, paniculate; rachis glabrous to puberulous, angles ciliate, and unarmed. Spikelets staminate and subandrogynous, in the same panicle. Staminate spikelets $3.5-4.7 \times 1.3-2.5 \mathrm{~mm}$, terete to ellipsoid, sessile to pedicellate; pedicel up to $1.2 \mathrm{~mm}$ long. Subandrogynous spikelets $4.4-5.1 \times 1.5-2.2 \mathrm{~mm}$, ellipsoid, sessile to pedicellate; pedicel up to $2.1 \mathrm{~mm}$ long. Glumes brown, puberulous, midrib glabrous, unarmed, margins ciliolate, apex mucronate. Stamens 3 per flower. Nutlets $4.2-6 \times$ 3.5-5 mm, subglobose, circular in cross-section, white to grayish-brown, surface smooth, glabrous, base lacking pores, apex rounded. Stylobase 1.5-2 mm long, conical, dark brown, persistent. Hypogynium developed, trilobed, lobes rounded, light brown, margin flat, apex entire. Cupules concave, trilobed, persisting at the fruit, margin ciliolate, trichomes $0.1-0.2 \mathrm{~mm}$ long, hyaline.

Selected material: BRAZIL. PARÁ: Altamira, Rio Xingu, Sítio Mata 3, 22/IX/2015, fl. and fr., Lobato, L.C.B. 4471 (IAN, MFS, MG); Belém, Ilha do Combú, próximo ao restaurante Ribeirinho, $1^{\circ} 29^{\prime} 54.64^{\prime \prime} \mathrm{S}, 48^{\circ} 27^{\prime} 39.25^{\prime \prime} \mathrm{W}$, 21/IX/2017, fl. and fr., Silva, F.A. 227 (MG); Bragrança, Jiquiri, 09/X/2012, fl. and fr., Souza, A.F.S. 14 (HBRA); Breves, Antônio Lemos, Igarapé Pixuna, 19/VII/1948, fl. and fr., Black, G.A. 48-2975 (IAN); Cametá, Sede municipal de Cametá, Campo de Natureza a cerca de $8 \mathrm{~km}$ da cidade, 02 $01^{\prime} 40^{\prime \prime}$ ', 49²6'48' W, 4/VII/2017, fl. and fr., Braga-Silva, C.L. et al., 135 (MG); Canaã dos Carajás, S11-D Estrada de acesso mozartinópolis, 12/V/2015, fl. and fr., Silva, D.F. 1028 (HCJS); Chaves, Unidade de Conservação Chaves, ilha do Marajó, costa norte da ilha, 06/VII/2013, fl. and fr., Mesquita, A.S. \& Rocha, A.E.S. 112 (MG); Gurupá, arredores do aeroporto, 07/VIII/1968, fl. and fr., Silva, M. 1470 (MG); Itaituba, $4^{\circ} 16^{\prime} 05^{\prime \prime} \mathrm{S}, 55^{\circ} 59^{\prime} 23^{\prime \prime} \mathrm{W}, 10 / \mathrm{V} / 2013$, fl. and fr., Lucas, F.C.A. 952 (MFS, MG); Marapanim, Vila de Marudá, praia do Crispim, 15/VI/1991, fl., Bastos, M.N. et al. 1016
(MG); Muaná, Rio Anabijú-Fazenda Rosário, 22/IV/1982, fl., Dantas, M. \& Nivaldo, S. 1073 (IAN); Parauapebas, área de captação de água do Parque Botânico, 16/X/1989, fl. and fr., Silva, J.P. 602 (HCJS); São Geraldo do Araguaia, APA Araguaia, Caminho para a trilha da biodiversidade, 06 $18^{\prime} 01.8^{\prime \prime}$ S, 48 27'39.5” W, 3/VII/2018, fl. and fr., Schneider, L. et al. 226 (MG); n.l., VII.1977, fl. and fr., Bouças, P. \& Pinheiro, G.S. 205 (IAN); Terra indígena Las Casas, aldeia Las Casas, 17/VIII/2010, fl. and fr., Coelho-Ferreira, M. et al. 584 (MG).

Comment: Scleria macrophylla is characterized by its linear to lanceolate leaf-blades (3.5-5.6 cm wide), with pseudopremorse apex, paniculate inflorescences (Fig. 1C), puberulous glumes, smooth and glabrous subglobose nutlets, and a persistent stylobase (Fig. 60), and ciliolate cupules persisting at the fruit (Fig. 6O). This species is placed in the S. subg. S. sect. Ophryoscleria, which is characterized by the ciliate cupule persisting at the fruit, and leaf-blades with pseudopremorse apex (Bauters et al. 2016). Between the species of this section occurring in the state of Pará, $S$. macrophylla resembles S. sprucei C.B.Clarke due to its broad leaf-blades (i.e., broader than $3 \mathrm{~cm}$ ). Nonetheless, they can be distinguished by the shape of their leaf-blades, which range from linear to lanceolate in S. macrophylla, while they are oblong in $S$. sprucei.

Distribution and habitat: Mexico, Belize, Costa Rica, Guatemala, Honduras, Nicaragua, Panama, Cuba, Jamaica, Trinidad and Tobago, Guyana, Suriname, French Guiana, Venezuela, Colombia, Ecuador, Peru, and Brazil. In Brazil, it is recorded for the Northern (RR, PA, RO, and TO), Northeastern (MA, PI, PE, and BA), Central-Western (MT, GO, DF, and MS), and Southeastern (MG) regions. In the state of Pará, it can be found growing in "capoeiras", "várzeas", "restingas", riparian forests, and anthropized environments.

16. Scleria martii (Nees) Steud., Syn. Pl. Glumac.2: 171. 1855. $\equiv$ Hymenolytrum martii Nees, Fl. Bras. 2(1): 176. 1842.

(Figs. 4H, 7A)

Herbs $60-92 \mathrm{~cm}$ tall, perennial, monoecious, erect or climbing, solitary; rhizomes knotted. Stems 4.1-9 mm wide, glabrous, angles glabrous, armed or not. Leaf-sheaths 6.3-12 cm long, chartaceous, glabrescent to puberulous, basal ones unwinged, distal ones winged, wings 4-10 $\times 0.1-0.3 \mathrm{~cm}$, margins glabrous, armed; ligule absent. Contraligules $0.8-1.7 \mathrm{~mm}$ long, acute to rounded, apex glabrous, membranous appendage $0.8-1.6 \mathrm{~cm}$ long. Leafblades $45-76 \times 1.2-1.5 \mathrm{~cm}$, linear, continuous to the sheath, abaxially glabrous or glabrescent, midrib armed toward the apex, adaxially glabrous with two armed ribs toward the apex, midrib glabrous to puberulous, margins glabrous and armed, apex entire. Involucral bracts $9.6-37 \times 0.6-1.5$ $\mathrm{cm}$, foliaceous, lanceolate. Inflorescences $6-10.5(-23) \times$ $7-10.3 \mathrm{~cm}$, paniculate; rachis puberulous, angles ciliate, 
and unarmed. Spikelets staminate and pistillate, in the same panicle. Staminate spikelets $3.5-5.5 \times 0.9-1.2 \mathrm{~mm}$, lanceoloid, subsessile or pedicellate; pedicel $0.5-5 \mathrm{~mm}$ long. Pistillate spikelets $5.5-6.5 \times 0.9-1.5 \mathrm{~mm}$, lanceoloid, subsessile or pedicellate; pedicel $0.5-3 \mathrm{~mm}$ long. Glumes dark-vinaceous with midrib green or brown with vinaceous maculae, glabrous to puberulous, midrib glabrous, armed, margins glabrous to ciliolate, apex mucronate. Stamens 3 per flower. Nutlets $2.2-3.5 \times 2.1-3 \mathrm{~mm}$, ovoid to subglobose, subtriangular in cross-section, white to purple, surface smooth or rugulose, puberulous, base lacking pores, apex obtuse. Stylobase absent. Hypogynium developed, trilobed, lobes triangular, yellowish-brown to brown, margin revolute, apex laciniate. Cupules flat, entire, persisting at the rachilla, margin glabrous.

Examined material: BRAZIL. PARÁ: Almeirim, Distrito de Monte Dourado, $1^{\circ} 09^{\prime} 48^{\prime \prime}$ S, 52 $37^{\circ} 35^{\prime \prime}$ W, 31/ VI/2016, fl. and fr., Forzza, R.C. \& Leal, E.S. 5922 (MG); Altamira, Serra do Cachimbo, Reserva Biológica Nascentes da serra do Cachimbo, 29/IX/2019, 9¹5'38.3" S, 5450'09.1" W, fl., Schneider, L. et al. 377 (MG); Marapanim, a 2 km para Vila, 17/II/1766, fl. and fr., Rosemiro 11 (MG); Novo Progresso, Serra do Cachimbo, Campo de Prova Brigadeiro Vellozo, 9²1'49.0" S, 54⒌'25.5” W, 25/IX/2019, fl. and fr., Schneider, L. et al. 295 (MG); Santarém, Rio Arapiriuns, Resex Tocantins/Arapiuns, localidade São José, IV/2009, fl. and fr., Rosário, C.S. 2340 (MG); São Geraldo do Araguaia, Trilha da Casa de Pedra, rumo a cachoeira quarta queda, 06 09'48.8" S, 48³3'19" W, 6/VII/2018, fl. and fr., Schneider, L. et al. 261 (MG); Óbidos, Flota de Trombetas, $0^{\circ} 58^{\prime} 10^{\prime \prime} \mathrm{S}$, 55 31'03" W, IV/2008, fl. and fr., Lobato, L.C.B. 3463 (MG); Oriximiná, Rio Paru do Oeste, Cachoeira Chuvisco, 07/ IX/1980, fl. and fr., Cid, C.A. et al. 2241 (INPA); n.l., Região do Ariramba, mata a L. do acampamento do Jamaracaru, 2/VI/1957, fl. and fr., Black, G.A. 57-19847 (IAN); Rio Jarí, Estrada do Munguba, 18/XII/1968, fl. and fr., Nilo T. Silva 1567 (IAN); Rio Jarí, Estrada do Caracurú, 8/I/1969, fl. and fr., Nilo T. Silva 1589 (IAN); Rio Trombetas near Cachoeira Porteira, 27/V/1974, fl. and fr., Campbell, D.G. et al. P22364 (INPA, MG).

Comment: Scleria martii presents erect or climbing growth, knotted rhizomes, basal leaf-sheaths unwinged plus winged apical ones, ligule absent, contraligule's membranous appendage present, pyramidal paniculate inflorescences with unisexual and congested spikelets (Fig. 4H), ovoid to subglobose, smooth or rugulose, and puberulous nutlets (Fig. 7A), and triangular hypogynium lobes with laciniate apex (Fig. 7A). While investigating some names for this species, we found descriptions that ambiguously used the ligule term (Clarke 1908; Pilger 1901). In some species of Scleria, the ligule is a critical characteristic but was historically applied to different structures (Camelbeke \& Goetghebeur 1999). This unprecise use of the ligule term made the use of some names unreliable, especially in $S$. subg. $S$. sect.
Hymenolytrum. In this section, the ligule is not generally observable in photos of types available online. Camelbeke (2002) studied the $S$. martii type and noted that this species does not present a ligule of trichomes, and its hypogynium lobes have laciniate apex. Thus, we were able to confirm that several specimens traditionally treated as $S$. martii (e.g., Santos \& Bastos 2014) are, in fact, S. violacea. This is supported by the presence of a ligule of trichomes and hypogynium lobes with an entire apex. While preparing our article on the diversity of Scleria in Amazonian restinga vegetation in the state of Pará, Brazil (Schneider \& Gil 2020b), we confirmed that the specimens with the contraligule's membranous appendage and pyramidal paniculate inflorescences, which are particular to this phytogeographic domain, as $S$. violacea.

Distribution and habitat: Guyana, Suriname, French Guiana, Venezuela, Bolivia, Colombia, Ecuador, Peru, and Brazil. In Brazil, it is recorded for the Northern (AM, RR, AP, PA, RO, and TO), Northeastern (MA, PI, and BA), CentralWestern (MT, GO, and MS), and Southeastern (MG) regions. In the state of Pará, it can be found growing in forests and savannas.

17. Scleria microcarpa Nees ex Kunth, Enum. Pl. 2: 341. 1837.

(Figs. 4D, 7B)

Herbs $0.7-1.7 \mathrm{~m}$ tall, perennial, monoecious, erect, solitary; rhizomes unknotted. Stems $2-3 \mathrm{~mm}$ wide, glabrous to glabrescent, angles glabrous, armed. Leafsheaths $4.2-11.3 \mathrm{~cm}$ long, papyraceous, glabrescent to pubescent, winged, wings $4.5-14.5 \times 0.2-0.3 \mathrm{~cm}$, margins glabrous, armed; ligule absent. Contraligules 3.1-5(-31) $\mathrm{mm}$ long, acute to lanceolate, apex glabrous or ciliate, membranous appendage absent. Leaf-blades 15.4-30.9 $\times 0.8-1.5 \mathrm{~cm}$, linear to lanceolate, continuous to the wings of the sheaths, abaxially glabrescent to pubescent, midrib armed, adaxially glabrescent to pubescent with two armed ribs toward the apex, midrib glabrous to pubescent, margins glabrous and armed toward the apex, apex pseudopremorse. Involucral bracts $3.5-25.6 \times$ $0.2-1 \mathrm{~cm}$, foliaceous, lanceolate. Inflorescences $42-50.6$ $\times 2-3 \mathrm{~cm}$, paniculate; rachis glabrous, angles ciliate, and unarmed. Spikelets staminate and subandrogynous, in the same panicle. Staminate spikelets 1.3-2.5 × 0.7-1.3 $\mathrm{mm}$, ellipsoid to terete, sessile to pedicellate; pedicel up to $2 \mathrm{~mm}$ long. Subandrogynous spikelets $1.5-2.3 \times$ 0.7-1.4 mm, ellipsoid, sessile to pedicellate; pedicel up to $1 \mathrm{~mm}$ long. Glumes stramineous to brown with red lines, glabrous, midrib glabrous, armed or not, margins glabrous to ciliolate, apex mucronate. Stamens 3 per flower. Nutlets $2.1-3 \times 1.3-2 \mathrm{~mm}$, ovoid to subglobose, subcircular in cross-section, white to grayish, surface smooth, glabrous, base lacking pores, apex rounded. Stylobase $0.5-0.6 \mathrm{~mm}$ long, conical to terete, light brown, deciduous. Hypogynium developed, trilobed, lobes 
rounded, light brown, margin flat, apex entire. Cupules concave, entire to obscurely trilobed, persisting at the nutlet, margin ciliate, trichomes $0.1-0.3 \mathrm{~mm}$ long, hyaline to brown.

Selected material: BRAZIL. PARÁ: [Alenquer], Sete varas airstrip on Rio curua, $0^{\circ} 60^{\prime} 35^{\prime \prime}$ S, 54 $60^{\circ} 32^{\prime \prime}$ W, 5/VIII/1981, fl. and fr., Strundwick, J.J. et al. 4140 (MG); Almeirim, 4/X/2012, fl. and fr., Householder, J.E. 2163 (INPA); Altamira, Margem direita do Rio Xingu, no largo do Muruci, 21/X/1986, fl. and fr., Vasconcelos, R.T.P. et al. 409 (MG); Belém, Ilha do combu, furo do Combu, desembarque no terreno do seu Rui, as margens do Igarapé do Tracuateua, próxima a plantação de cacau, 16/VIII/2015, fl. and fr., Schneider, L. et al. 61 (MG); Belterra, Belo Monte, 51 batalhão da Selva, Floresta, 3¹2'12" S, 52 20'64" W, 18/III/2001, fl. and fr., Suemitsu, C. 1188 (HSTM); Bragança, $7 \mathrm{~km}$ east of Bragança along road to Augusto Correa, ca. $1^{\circ} 03^{\prime} 00^{\prime \prime}$ S, 46 40'00" W, 07/IV/1980, fl. and fr., Davidse, G. et al. 18009 (MG); Cametá, Sede Municipal de Cametá, 02¹5'2" S, 49³7'13" W, 3/VII/2017, fl. and fr., Braga-Silva, C.L. et al. 107 (MG); Canaã dos Carajás, Corpo A Floresta Nacional de Carajás, 6¹9'275" S, 0²7'84" W, 16/II/2010, Costa, L.V. 711 (HCJS); Conceição do Araguaia, Rio Araguaia, Praia de Santana, 23/IX/2000, fl. and fr., Lobato, L.C.B. et al. 2661 (MG); Faro, Lago de Faro, acima do Tauacuera, 12/II/1910, fl., Ducke, A. s.n. (MG10673); Itaituba, Rio Crepori, Corredeira Porto Alegre, 18/VIII/2018, Egler, S. 22 (RB); Jacareacanga, Alto Tapajós, Rio Cururú, Missão Velha, 10/II/1960, fl. and fr., Egler, W.A. 1294 (MG); Juruti, 05/VI/2014, fl. and fr., Salomão, R.P. et al. 1399 (MG); Marapanim, próximo ao trevo do Camará, 0³6'23" S, 47 40'27' W, 06/VI/2017, fl. and fr., Schneider, L. et al. 118 (MG); Moju, Comunidade São bernardinho, sítio Arqueológico do Rio "Jambu-Acu",15-25/III/2005, fl. and fr., Lobato, L.C.B. 3171 (MG); [Monte Alegre], Rio Maicuru, proximidades da pista de pouso do lageiro aprox. $1^{\circ} 00^{\prime} 00^{\prime}$ ' S, 54 $30^{\circ} 00^{\prime}$ 'W, 18/VII/1981, fl. and fr., Jangoux, J. \& Ribeiro, B.G.S. 1455 (MG); [Ourilândia do Norte], Marshy campo and low wet florest near canal SE of Missão Cururú, $7^{\circ} 35^{\prime} 00^{\prime \prime}$ S, 5131'00” W, 8/II/1974, fl. and fr., Anderson, W.R. 10671 (IAN); Oriximiná, Rio Trombetas, Mineração Rio do Norte, XII/1999, fl. and fr., Quintela, M.F. s.n. (MG159941); Parauapebas, Serra da bocaina, 6¹7'3" S, 49 $55^{\prime} 2^{\prime \prime}$ W, 15/XII/2010, fl. and fr., Mota, N.F.O. et al. 1857 (HCJS); Ponta de Pedras, $1^{\circ} 21^{\prime} 4$ " S, 48 56'34" W, 18/XII/2003, fl. and fr., Silva, A.S.L. \& Rosário C.S. 4131 (MG); Salvaterra, Lagoa do Hotel Pousada dos Guarás, reserva ecológica de Salvaterra, 16/I/92, fl. and fr., Rosa, N.A. et al. 5573 (MG); Santarém, Confluência do Rio Muji com rio Curuá-Uma, 23/II/1981, fl. and fr., Yamamoto, I.M. 111 (INPA); Senador José Porfírio, Baixo Rio Xingu, ilha do Mucuripe, 23/X/1984, fl. and fr., Almeida, S. 151 (MG); [Tucuruí], approx. $25 \mathrm{~km}$ from Tucurui, SW on new road serving fazendas, road construction site, approx. $3^{\circ} 55^{\prime} 00^{\prime \prime} S$, $49^{\circ} 47^{\prime} 00^{\prime \prime}$ W, 15/XI/1981, fl. and fr., Dally, D.C. et al. 1360 (MG); n.1., várzea do Rio Guamá near Pará, 4/I/1907, fl. and fr., Buher 151 (MG).

Comment: Scleria microcarpa presents winged leafsheaths, blades continuous to the wing sheath, with pseudopremorse apex, paniculate inflorescences with inconspicuous spikelets (Fig. 4D), ovoid to subglobose nutlets with a smooth and glabrous surface, a deciduous stylobase, and a ciliate cupule persisting at the fruit (Fig. 7B). Among the members of the $S$. subg. S. sect. Ophryoscleria that occur in the state of Pará, S. microcarpa resembles $S$. mitis P.J.Bergius, mainly due to its narrow leaf-blades (i.e., less than $3 \mathrm{~cm}$ wide), and small fruits (i.e., 2.1-4 mm long). However, they can be differentiated by the length of their contraligules [4-5(-31) $\mathrm{mm}$ in S. microcarpa vs. 3.6-4 cm in S. mitis], the pubescence of the abaxial leafblade (glabrescent to pubescent $v s$. glabrescent with two pubescent ribs), and the pubescence of the cupule (with hyaline to brown trichomes vs. golden and red). Scleria microcarpa also resembles $S$. eggersiana Boeck., which does not occur in the study area. However, they can be distinguished by the width of their leaf-blades (0.8-1.5 $\mathrm{cm}$ in S. microcarpa vs. up to $2.5 \mathrm{~cm}$ in S. eggersiana), and fruit size $(2.1-3 \times 1.5-2 \mathrm{~mm}$ vs. $3.2-4.9 \times 2.5-3.2 \mathrm{~mm})$. Among the studied specimens of $S$. microcarpa, we noticed that the pubescence of the leaf-sheaths and blades varied according to the environment each specimen occurred. In flooded and shady areas, these structures were pubescent, while in open fields, and sandy or dry soils, they were glabrescent.

Distribution and habitat: South of Mexico to Tropical America. In Brazil, it is recorded for the Northern (AC, AM, RR, AP, PA, and RO), Northeastern (MA, PI, CE, RN, PE, $\mathrm{PB}, \mathrm{AL}$, and $\mathrm{SE}$ ), Central-Western (MT, GO, DF, and MS), Southeastern (MG, ES, RJ, and SP), and Southern (PR and $\mathrm{SC}$ ) regions. In the state of Pará, it can be found growing in rainforests, riparian forests, "campinaranas", "várzeas", savannas, "restingas", "campos rupestres", and anthropized environments.

18. Scleria mitis P.J.Bergius, Kongl. Vetensk. Acad. Handl. 26: 145, pl. 5. 1765.

(Figs. 1D, 7C)

Herbs $0.5-1.6 \mathrm{~m}$ tall, perennial, monoecious, erect, solitary; rhizomes not seen. Stems $3-7 \mathrm{~mm}$ wide, glabrous or glabrescent, angles glabrous, armed or not. Leaf-sheaths $6-20 \mathrm{~cm}$ long, papyraceous or chartaceous, glabrescent or pubescent, winged, wings 6-16.9 × 0.2-0.5 $\mathrm{cm}$, margins glabrous, armed; ligule absent. Contraligules $3.6-4 \mathrm{~cm}$ long, long-lanceolate, apex glabrous or ciliate, membranous appendage absent. Leaf-blades 33.3-63.3 $\times$ $1.5-2.2 \mathrm{~cm}$, linear, continuous to the wings of the sheaths, abaxially glabrous with two pubescent ribs, midrib armed or not, adaxially glabrous with two armed ribs, midrib 
glabrous or pubescent, margins glabrous and armed, apex pseudopremorse. Involucral bracts $9-21.3 \times 0.5-2 \mathrm{~cm}$, foliaceous, linear. Inflorescences $42-54.8 \times 3.5-7 \mathrm{~cm}$, paniculate; rachis glabrous, angles glabrous, and armed or not. Spikelets staminate and subandrogynous, in the same panicle. Staminate spikelets $2.3-3 \times 1.2-1.7$ $\mathrm{mm}$, ellipsoid, subsessile to pedicellate; pedicel 0.3-1.7 $\mathrm{mm}$ long. Subandrogynous spikelets $2.8-3.5 \times 1.5-$ $1.8 \mathrm{~mm}$, ellipsoid, subsessile; pedicel $0.3-0.5 \mathrm{~mm}$ long. Glumes light brown with red lines, glabrous, midrib glabrous, armed, margins ciliolate, apex mucronate. Stamens 3 per flower. Nutlets $2.5-4 \times 1.8-3.5 \mathrm{~mm}$, globose to subglobose, circular in cross-section, white to yellowish-brown, surface smooth, glabrous, base lacking pores, apex rounded. Stylobase $0.5-1 \mathrm{~mm}$ long, conical, dark, persistent. Hypogynium developed, trilobed, lobes rounded, light brown, margin flat, apex entire. Cupules concave, entire to obscurely trilobed, persisting at the nutlet, margin ciliate, trichomes $0.3-0.7 \mathrm{~mm}$ long, golden and red.

Supplementary description: Rhizome present (Core 1936).

Examined material: BRAZIL. PARÁ: Afuá, Rio Marajózinho, 12/IX to 02/X.1992, fl. and fr., Maciel, U.N. \& Santos, M.R. 1843 (MG); Anajás, Fazenda Santa Quitéria, 20/VIII/1982, fl. and fr., Cordeiro, M.R. 1713 (IAN); Barcarena, foz do Rio Conde, 19/VI/1984, fl. and fr., Lins, A. et al. 334 (MG); Belém, Ilha do Combu, furo do Combu, desembarque no terreno do seu Rui, as margens do Igarapé do Tracuateua, próxima a plantação de cacau; 19/VIII/15, fl. and fr., Schneider, L. et al. 60 (MG); Benfica, estabelecimento do Sr. Cícero Cosme de Souza, 05¹6'17.71" S, 4949'49.93” W, 25/X/2006, fl. and fr., Mitja, D. \& Carvalho, D.C. 10149 (MG); Cametá, campo de Natureza ca. de $8 \mathrm{~km}$ da cidade, estrada CametáAjurú, 0201'40" S, 49 $26^{\prime} 48^{\prime \prime}$ W, 4/VII/2017, fl. and fr., Braga-Silva, C.L. et al., 134 (MG); Chaves, Unidade de Conservação Chaves, Ilha do Marajó, Costa Norte da Ilha, 20/VIII/13, fl. and fr., Mesquita, A.S. \& Rocha, A.E.S. 111 (MG); Curuçá, Rio Cupari, 3/I/1948, fl. and fr., Black, G.A. 48-2283 (IAN); Monte Alegre, Igapó Grande, V/1996, fl. and fr., Projeto IARA s.n. (IAN164428); Muaná, próximo a fazenda S. Antônio, R. Afuá, 31/X/1970, fl. and fr., Oliveira, E. 5394 (IAN); n.1., Ingatubinha, 28/VII/1947, fl. and fr., Black, G.A. 47-2113 (IAN); Beira do Rio Guamá, acima de São Miguel, 30/X/1948, fl. and fr., Black, G.A. 48-3365 (IAN); Margem esquerda do Rio Moju, embocadura do Igarapé Jambuassú, 7/VII/1967, fl. and fr., Silva, M. 1019 (MG); Região do Rio Mojú, Rio Cairari, 25/III/1957, fl. and fr., Fróes, R.L. 33141 (IAN).

Comment: Scleria mitis is characterized by its winged leaf-sheaths, longly-lanceolate contraligule, leaf-blades continuous to the wings of the sheath, abaxially with two pubescent ribs and pseudopremorse apex, paniculate inflorescences (Fig. 1D), subglobose nutlet with a smooth and glabrous surface, a persistent stylobase (Fig. 7C), and a ciliate cupule with golden and red trichomes, persisting at the fruit (Fig. 7C). Among the species that occur in the state of Pará, S. mitis resembles $S$. microcarpa (see the comment for $S$. microcarpa). This species can also be confused with S. sororia Kunth, which does not occur in the study area, being only recorded for Southeastern Brazil. Scleria mitis can be distinguished from S. sororia by its entire to inconspicuously trilobed cupule, ciliate with golden and red trichomes (vs. conspicuously trilobed, with yellowish trichomes in $S$. sororia), and persistent stylobase (vs. deciduous).

Distribution and habitat: Belize, Costa Rica, Guatemala, Honduras, Nicaragua, Panama, Cuba, Dominican Republic, Haiti, Trinidad and Tobago, Guyana, Suriname, French Guiana, Venezuela, Bolivia, Colombia, Ecuador, Peru, Brazil, and Paraguay. In Brazil, it is recorded for the Northern (AC, AM, RR, AP, PA, RO, and PI), Northeastern (MA, PI, CE, RN, PE, PB, Al, and SE), Central-Western (MT, GO, DF, and MS), Southeastern (MG, ES, RJ, and SP), and Southern (PR) regions. In the state of Pará, it grows in "várzeas" and riparian forests.

19. Scleria pusilla Pilg., Bot. Jahrb. Syst. 30(1): 144. 1901.

(Figs. 4E, 7D)

Herbs ca. $40 \mathrm{~cm}$ tall, annual, monoecious, erect, caespitose; rhizomes absent. Stems ca. $0.5 \mathrm{~mm}$ wide, glabrous, angles glabrous, unarmed. Leaf-sheaths 2.3-3.4 cm long, membranous, pubescent, unwinged, margins glabrous, unarmed; ligule absent. Contraligules truncate, apex ciliate, membranous appendage absent. Leaf-blades $16-17.5 \times 0.1-0.2 \mathrm{~cm}$, linear, continuous to sheath, abaxially glabrous, midrib armed toward the apex, adaxially glabrous, midrib glabrous, unarmed, margins glabrous and armed toward the apex, apex entire. Involucral bracts $2.5-4 \times 0.4-0.5 \mathrm{~mm}$, glumaceous, lanceolate. Inflorescences $6-16 \times 2.5-5 \mathrm{~cm}$, spiciform, branched; rachis glabrous, angles glabrous, and unarmed. Androgynous spikelets $3.1-4 \times 0.6-1 \mathrm{~mm}$, terete, sessile. Glumes light brown with red lines and midrib green, glabrous, midrib glabrous, armed, margins glabrous, apex apiculate. Stamens 3 per flower. Nutlets 1.5-1.6 $\times 1-1.3 \mathrm{~mm}$, subglobose, subtriangular in cross-section, white, surface crested-reticulate and papillose, glabrous, base lacking pores, apex apiculate. Stylobase absent. Hypogynium reduced, dark brown. Cupules flat, trilobed, persisting at the rachilla, margin glabrous.

Examined material: BRAZIL. PARÁ: Conceição do Araguaia, Range of hills ca. $20 \mathrm{~km}$ wets of Redenção, near Côrrego São João and Troncamento Santa Teresa, $8^{\circ} 03^{\prime} 00^{\prime \prime}$ S, 50¹0'00" W, 10/II/1980, fl. and fr., Plowman, T. et al. 8664 (INPA).

Comment: Scleria pusilla is characterized by the contraligule lacking a membranous appendage, 
branched spiciform inflorescences (Fig. 4E), glumes with inconspicuously armed midrib, globose nutlets with crestedreticulate and papillose surface (Fig. 7D), and nutlet base with depressions, but not forming pores (Fig. 7D). This species is placed in S. subg. H. sect. Hypoporum. Among the species recorded for the state of Pará, S. pusilla is similar to $S$. tenella and $S$. sp., mainly by the glabrous leaf-blades, glumes with inconspicuously armed midrib, and nutlets subtriangular in cross-section. Nevertheless, S. pusilla is distinguished from $S$. tenella by the contraligule lacking a membranous appendage (vs. present), glabrous and unarmed inflorescence rachis (vs. ciliate or armed), and male flowers with three stamens (vs. one). Scleria pusilla differs from $S$. sp. for having a branched inflorescence (Fig. $4 \mathrm{E} v s$. unbranched inflorescence - Fig. $5 \mathrm{H}$ ), three stamens per flower (vs. two), and a subglobose nutlet (Fig. 7D vs. obovoid - Fig. 7O).

Distribution and habitat: Guyana and Brazil. In Brazil, it is recorded for the Northern (PA) and Central-Western (MT and GO) regions. In the state of Pará, it can be found growing in savannas.

20. Scleria reticularis Michx. Fl. Bor.-Amer.2: 167. 1803.

(Figs. 4I, 7E)

Herbs 36.2-67 m tall, perennial, monoecious, erect, caespitose; rhizomes absent. Stems $1-2.3 \mathrm{~mm}$ wide, glabrous, angles glabrous, armed or not. Leaf-sheaths 2.8-6.1 cm long, membranous, glabrous to pubescent, basal ones unwinged, distal ones winged, wings 2.5$2.8 \times 0.4-0.5 \mathrm{~cm}$, margins glabrous, unarmed; ligule absent. Contraligules up to $0.5 \mathrm{~mm}$ long, concave to trapeziform, apex ciliate, membranous appendage 0.3-0.7 $\mathrm{mm}$ long. Leaf-blades $(5.2-) 14-24.9 \times 0.1-0.5 \mathrm{~cm}$, linear, continuous to the sheath, abaxially glabrous or glabrescent, midrib armed, adaxially glabrous, midrib glabrous, unarmed, margins glabrous or ciliate, and armed or not, apex entire. Involucral bracts $2.8-12.2(-24.4)$ $\times 0.1-0.4 \mathrm{~cm}$, foliaceous, lanceolate. Inflorescences $13.5-37 \times 1.2-2.5 \mathrm{~cm}$, paniculate; rachis glabrous or pubescent, angles ciliate, and armed or not. Spikelets staminate and subandrogynous, in the same panicle. Staminate spikelets $3.3-4.5 \times 0.7-1 \mathrm{~mm}$, terete, pedicellate; pedicel 2-7 mm long. Subandrogynous spikelets $4.6-5.5 \times 0.8-1.4 \mathrm{~mm}$, lanceoloid to terete, pedicellate; pedicel 1.8-4 $\mathrm{mm}$ long. Glumes stramineous to light brown with vinaceous margins and midrib green, glabrous or glabrescent, midrib glabrous, armed, margins glabrous, apex mucronate. Stamens 3 per flower. Nutlets 1.9-2.8 $\times 1.4-2 \mathrm{~mm}$, globose to subglobose, circular in cross-section, white to yellowish-brown, surface crestedreticulate, pubescent, base lacking pores, apex apiculate. Stylobase absent. Hypogynium developed, trilobed, lobes oblong, white to light brown, margin flat, apex entire. Cupules concave, trilobed, persisting at the rachilla, margin glabrous.

Examined material: BRAZIL. PARÁ: Bragança, Península de Ajuruteua, dunas e campos ao noroeste de Vila Bonifácio, 050'17.4” S, 46³7'36.8” W, 10/V/2007, fl. and fr., Mehlig, U. 331 (HBRA); Cametá, Estrada de CametáJuaba, 2²0'7" S, 49³4'21” W, 06/VII/2017, fl. and fr., Gil, A. et al. 792 (MG); Maracanã, Ilha de Algodoal, 22/V/2008, fl. and fr., Rodrigues, L.K.M. 26 (IAN, MG); Marapanim, 1,5 $\mathrm{km}$ do trevo para Camará, $0^{\circ} 36^{\prime} 7^{\prime \prime} \mathrm{S}, 47^{\circ} 40^{\prime} 27^{\prime \prime} \mathrm{W}, 6 / \mathrm{VI} / 2017$, fl. and fr., Schneider, L. et al. 129 (MG); Muaná, Rio Afuá, Mariahy, 20/IV/1982, fl. and fr., Dantas, M. \& Nivaldo, S. 980 (IAN); Salinópolis, Restinga da Praia do Atalaia, 20/ IX/2013, fl. and fr., Gil, A. et al. 317 (MG); Salvaterra, 22/ IX/1988, fl. and fr., Silva, A.S.L. \& Rosário, C.S. 2085 (MG); Santarém, Vila Nova, 7/VII/2007, fl. and fr., Sofia, A. 104 (HSTM); São Geraldo do Araguaia, trilha para o ninho da Harpia, fl. and fr., 27/VIII/2018, Nunes, C.S. 413 (MG); Tucuruí, $3^{\circ} 55^{\prime} 00^{\prime \prime}$ S, 4947'00" W, 15/XI/1981, fl. and fr., Daly, D.C. et al. 1360 (INPA); Viseu, Fernandes Belo, vila do Apeú-Salvador, 055'19.8” S, 46²'16.7” W, 23/VI/2015, fl. and fr., Mehlig, U. 1635 (MG); n.1., IX.1986, fl. and fr., Soares, E. 432 (INPA); Marajó, Granja estrela, Rio Anabijú, 6/VII/1962, fl. and fr., Oliveira, E. 2118 (IAN); Região do Ariramba, Campo do quebra dente, 30/V/1957, fl. and fr., Egler, W.A. 393 (MG); Região do Ariramba, Campo do quebra dente, 30/V/1957, fl. and fr., Black, G.A. 57-19758 (IAN); Rio Camará, Pau Grande, fazenda Santa Rita, 8/VII/1950, fl. and fr., Black, G.A. 50-9989 (IAN).

Comment: Scleria reticularis is characterized by its unwinged basal sheaths plus winged distal sheaths, contraligule's membranous appendage inconspicuous, few branched paniculate inflorescences (Fig. 4I), globose nutlet with crested-reticulate and pubescent surface (Fig. 7E), and trilobed hypogynium with oblong lobes and acuminate apex (Fig. 7E). This species is placed in S. subg. S. sect. Foveolidia (Bauters et al. 2016). It occurs in Brazil, together with two more species of the same section (i.e., S. clarkei Lindm. and S. lagoensis Boeck). Scleria reticularis is distinguished from the $S$. clarkei by its glabrous or glabrescent leafblades (vs. pubescent or pilose) and the crested-reticulate nutlet (vs. smooth). Also, S. reticularis is distinguished from the $S$. lagoensis by its presence of the contraligule's membranous appendage (vs. absent), oblong hypogynium lobes (vs. lanceolate), and crested-reticulate nutlet (vs. inconspicuously reticulate).

Distribution and habitat: East, Central and Southern USA, Mexico, Belize, Costa Rica, Guatemala, Honduras, Nicaragua, Panama, Cuba, Dominican Republic, Haiti, Puerto Rico, Trinidad and Tobago, Guyana, Suriname, French Guiana, Venezuela, Bolivia, Colombia, Ecuador, Brazil, and Argentina. In Brazil, it is recorded for the Northern (RR and $\mathrm{PA})$, Northeastern (MA, PI, CE, RN, PE, PB, AL, SE, and BA) and Central-Western (GO) regions. In the state of Pará, it grows in "campinas", "restingas", and savannas. 
21. Scleria scabra Willd., Sp. Pl. 4: 315. 1805.

(Figs. 5A, 7F)

Herbs ca. $60 \mathrm{~cm}$ tall, perennial, monoecious, erect, solitary; rhizomes knotted. Stems ca. $2 \mathrm{~mm}$ wide, glabrescent, angles glabrous, armed. Leaf-sheaths $4.7-5.5 \mathrm{~cm}$ long, papyraceous, glabrous, winged, wings $4.2-5.3 \times$ ca. $0.1 \mathrm{~cm}$, margins glabrous, armed; ligule surrounding the sheath, trichomes $0.5-0.6 \mathrm{~mm}$ long, dense, golden. Contraligules 3-4 mm long, acute, apex glabrous, membranous appendage $0.7-1.1 \mathrm{~mm}$ long. Leafblades ca. $22 \times 0.5 \mathrm{~cm}$, linear, continuous to the sheath, abaxially glabrous, midrib armed toward the apex, adaxially puberulous to glabrescent, midrib puberulous, margins glabrous and armed, apex entire. Involucral bracts $4-6$ $\times 0.3-0.5 \mathrm{~cm}$, foliaceous, lanceolate. Inflorescences ca. $5(-23) \times 2.5-7 \mathrm{~cm}$, paniculate; rachis pubescent, angles ciliate, and unarmed. Spikelets staminate and pistillate, in the same panicle. Staminate spikelets $4.5-5.1 \times 0.9-$ $1.1 \mathrm{~mm}$, lanceoloid, pedicellate; pedicel 1-1.5 mm long. Pistillate spikelets ca. $8 \times 1.5 \mathrm{~mm}$, lanceoloid, subsessile to pedicellate; pedicel $0.5-2.1 \mathrm{~mm}$ long. Glumes light brown with red dots, glabrous to puberulous, midrib glabrous, unarmed, margins glabrous, apex mucronate. Stamens 3
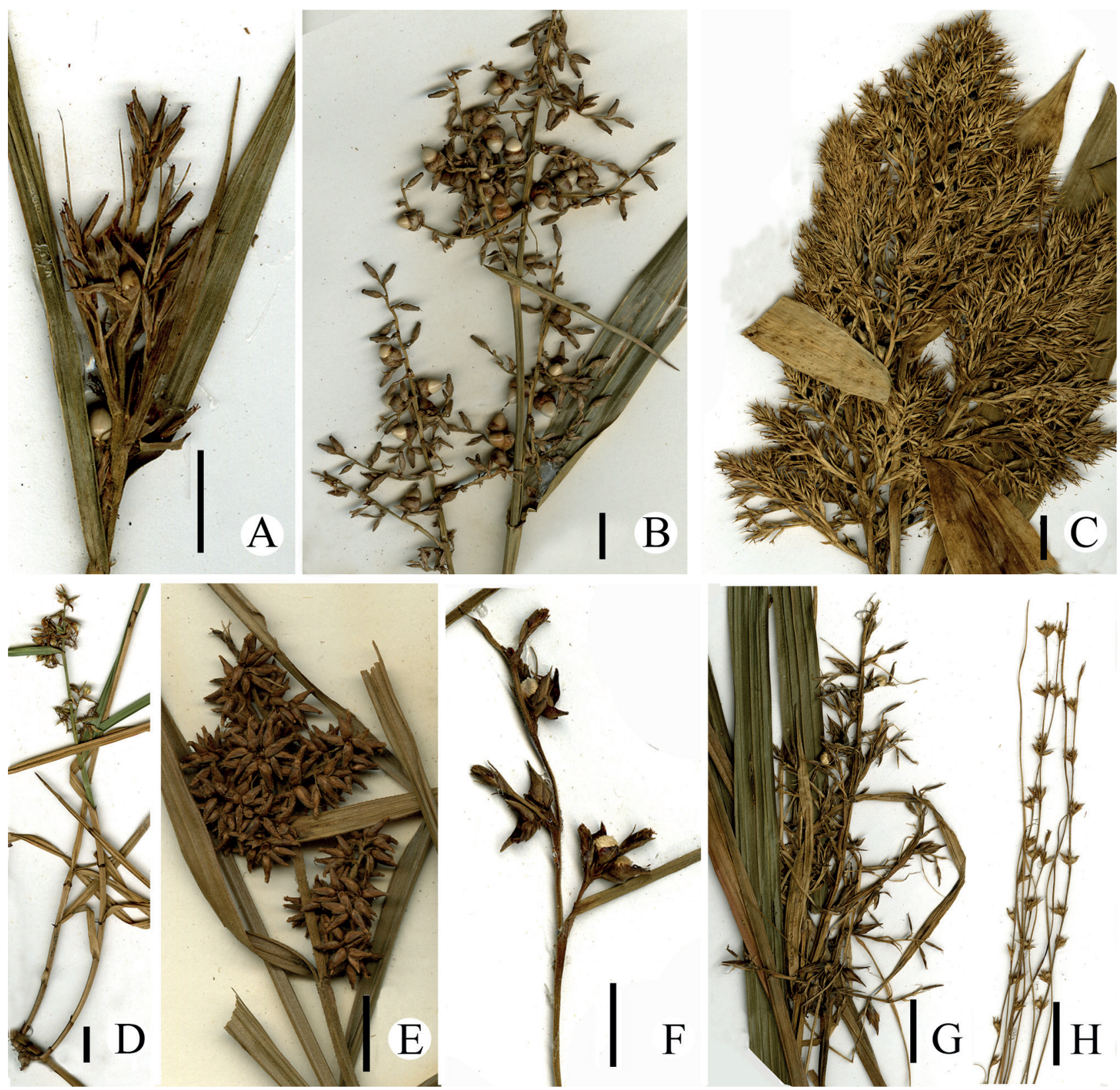

Figure 5. Inflorescences. A. Scleria scabra (Lobato, L.C.B. 3613). B. S. sprucei (Prance, G.T. 24848). C. S. stipularis (Forzza, R.C. 5924). D. S. tenacissima, pistillate (Mortati, A.F. 40). E. S. tenacissima, staminate (Maciel, U.N. 171). F. S. triquetra (Barbosa, E.M. 44). G. S. vaginata (Gil, A. 518). H. Scleria sp. (Lobato, L.C.B. 3012). Scale $1 \mathrm{~cm}$. Images: Layla J.C. Schneider. 


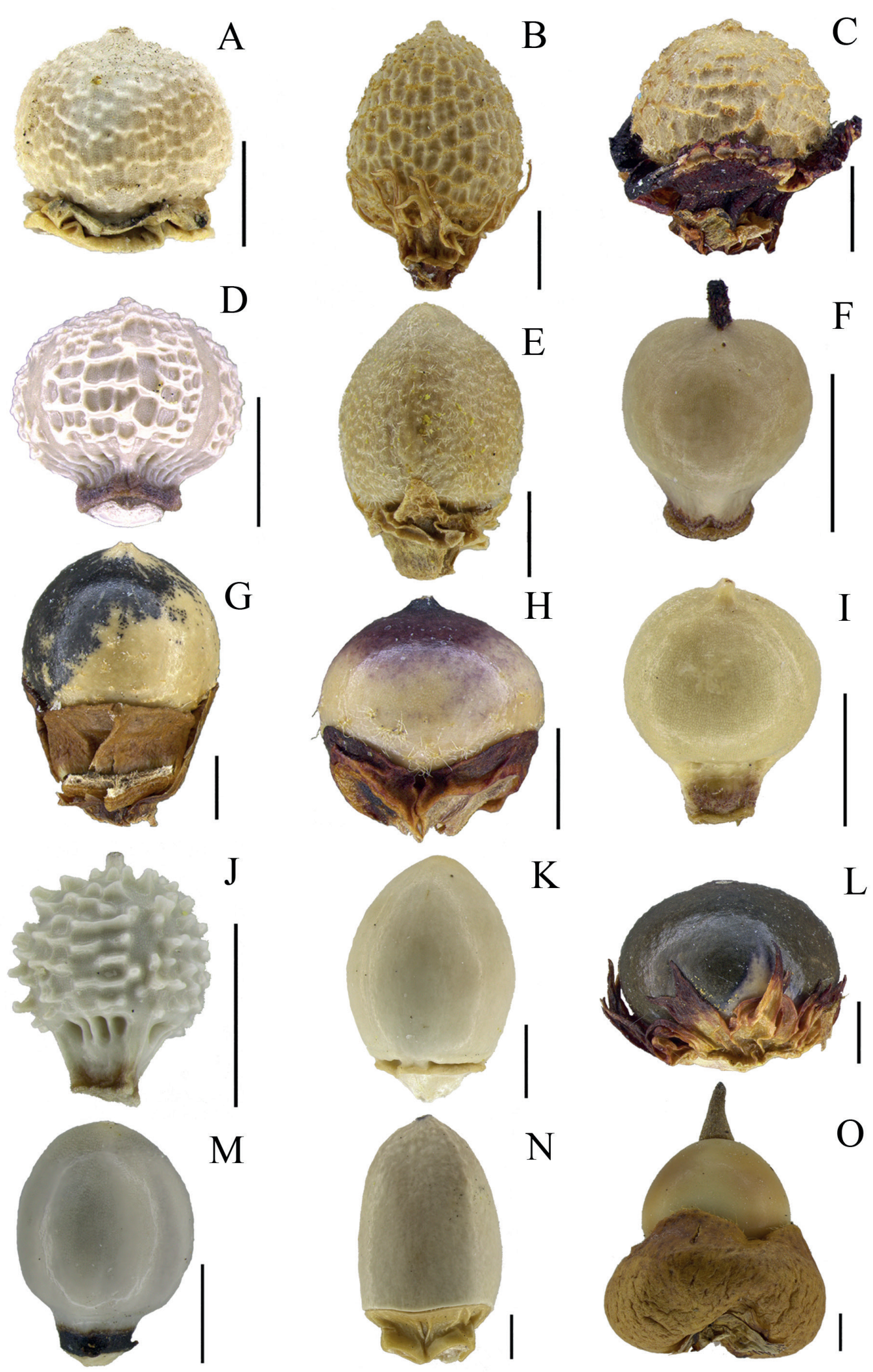

Figure 6. Nutlets. A. Scleria amazonica (Braga-Silva, C. 76). B. S. arguta (Cordeiro, M.R. 750). C. S. bracteata (Oliveira, E. 6632). D. S. burchellii (Pinheiro, C.S. 546). E. S. cyperina (Souza, M.G.C. 462). F. S. distans (Cavalcante, P. 2416). G. S. flagellum-nigrorum (Salomão, R.P. 1238). H. S. gaertneri (Vieira, I.C. 29). I. S. hirtella (Miranda, V.C. 3092). J. S. interrupta (Santos, L.O. 385). K. S. lacustris (Kubitzki, K. 88B). L. S. latifolia (Silva, C.A.S. 48). M. S. lithosperma (Plowman, T. 8980). N. S. longigluma (Pena, B.S. 216). O. S. macrophylla (Silva, M. 1470). Scale $1 \mathrm{~mm}$. Images: C, H, I, J and O, adapted of Schneider \& Gil 2020b; the others, Layla J.C. Schneider. 

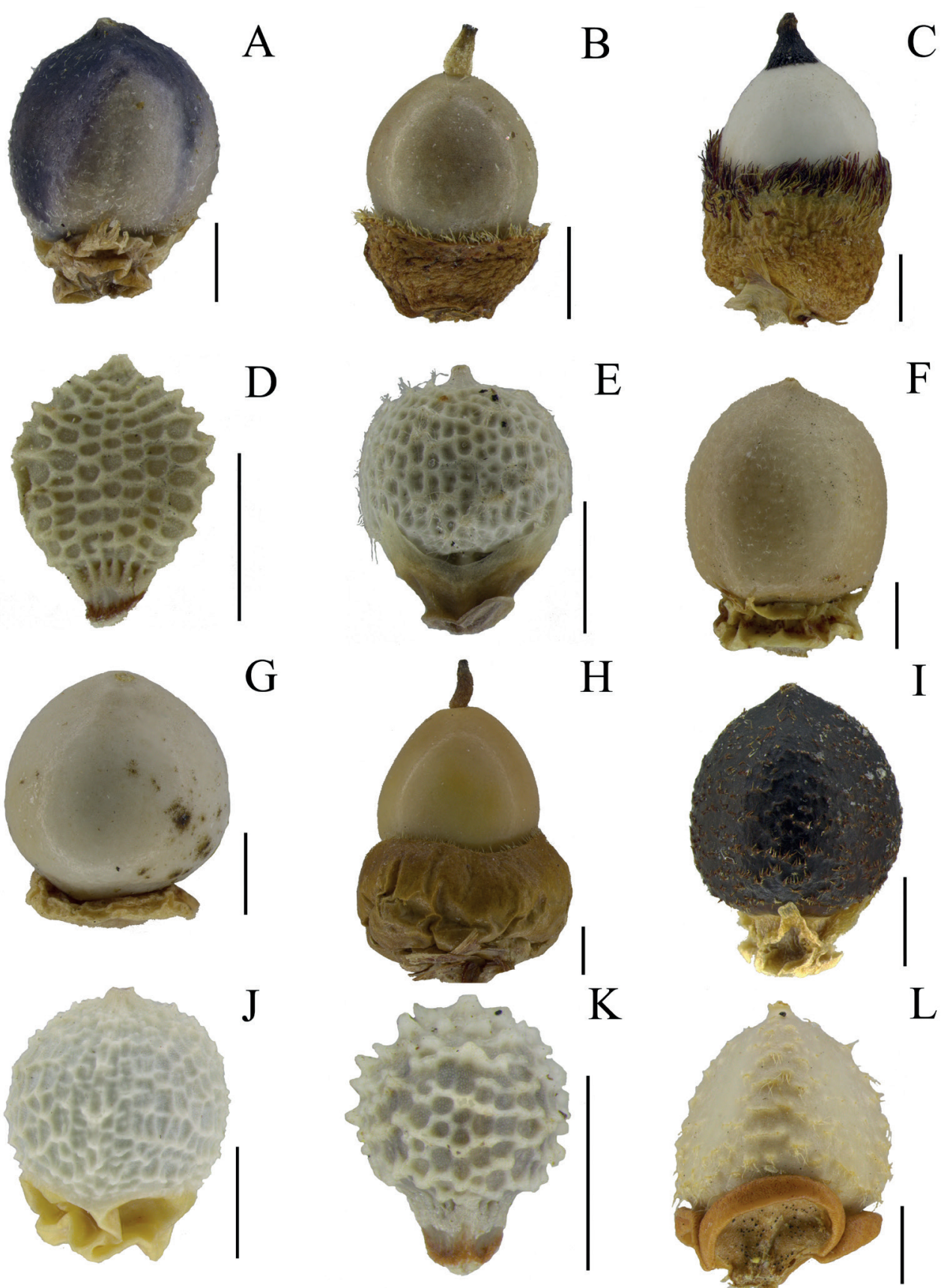

K
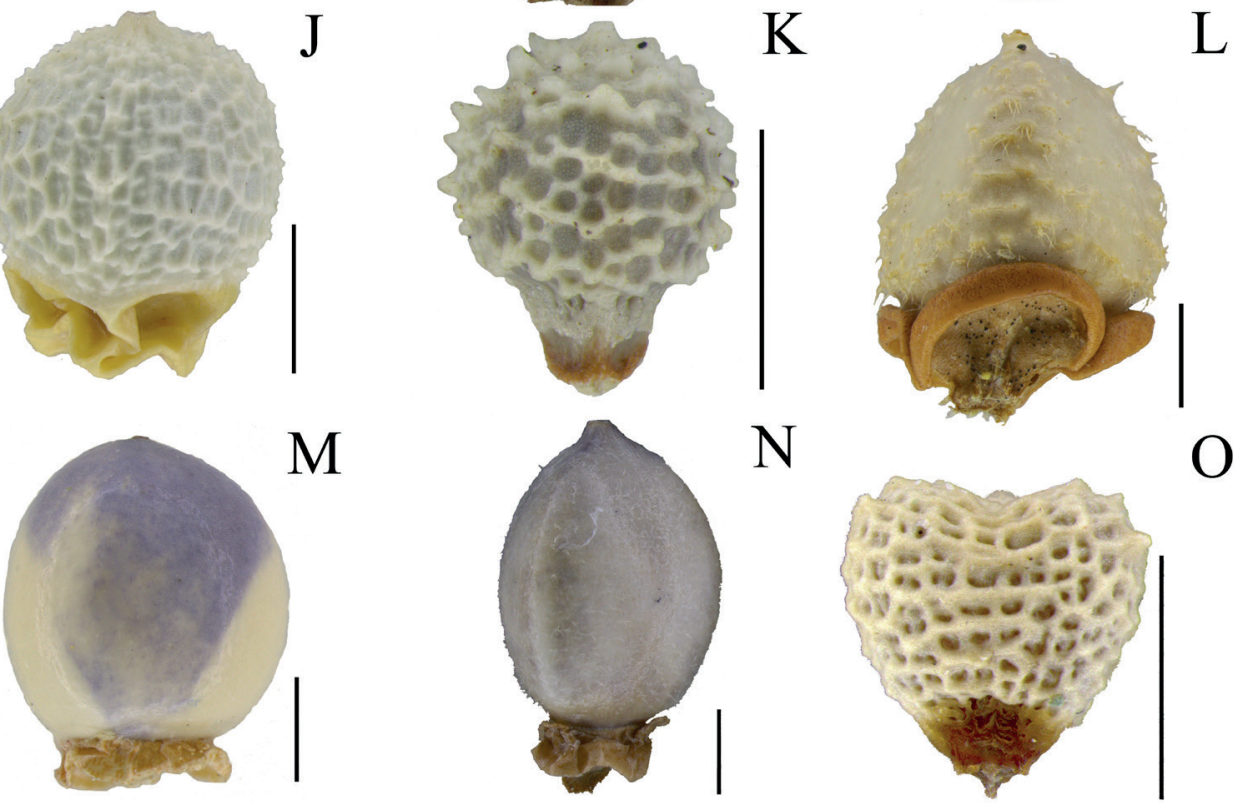

Figure 7. Nutlets. A. Scleria martii (Alves, K.N.L. 116). B. S. microcarpa (Rosa, N.A. 5573). C. S. mitis (Schneider, L. 60). D. S. pusilla (Plowman, T. 8664). E. S. reticularis (Schneider, L. 127). F. S. scabra (Sanaiotti, T.M. 21). G. S. secans (Schneider, L. 90). H. S. sprucei (Prance, G.T. 24848). I. S. stipularis (Forzza, R.C. 5424). J. S. tenacissima (Mortati, A.F. 40). K. S. tenella (Alves, K.N.L. 26). L. S. triquetra (Barbosa, E.M. 44). M. S. vaginata (Schneider, L. 161). N. S. violacea (Maciel-Silva, J.F. 201). O. Scleria sp. (Lobato, L.C.B. 2612). Scale 1 mm. Images: B, E, G and N, adapted of Schneider \& Gil 2020b; the others, Layla J.C. Schneider. 
per flower. Nutlets ca. $4.5 \times 2.7 \mathrm{~mm}$, ovoid, subtriangular in cross-section, white to light brown, surface smooth or rugulose, puberulous or glabrous, base lacking pores, apex attenuate. Stylobase absent. Hypogynium developed, trilobed, lobes triangular, light brown, margin revolute, apex laciniate. Cupules flat or slightly concave, entire, persisting at the rachilla, margin glabrous.

Selected material: BRAZIL. PARÁ: Novo Progresso, Serra do Cachimbo, Campo de Prova Brigadeiro Vellozo, 9'19'54.1" S, 55 01'50.3" W, 02/X/2019, fl. and fr., Schneider, L. et al. 402 (MG); Santarém, Alter-do-Chão, Península em frente a Alter-do-chão, 2²9'00" S, 5457'00” W, 22/ IV/1989, fl. and fr., Sanaiotti, T.M. 21 (INPA); Redenção, 10-20/IV/2009, fl. and fr., Lobato, L.C.B. et al. 3613 (MG); n.1., $1 \mathrm{~km}$ Estreito-Marabá, 4/IV/1974, fl. and fr., Pinheiro, G.S. 132 (UB); Rio camará, Fazenda Santa Rita, III/1950, fl. and fr., Rubens Lima 61 (IAN); Serra do cachimbo, XII/1956, fl., Pires, J.M. s.n. (IAN91977).

Comment: Scleria scabra is characterized by its knotted rhizomes, winged and ligulate leaf-sheaths, the presence of the contraligule's membranous appendages, pyramidal paniculate inflorescences (Fig. 5A), ovoid nutlets with a smooth or rugulose surface, ranging from puberulous or glabrous (Fig. 7F), and trilobed hypogynium with triangular lobes, with inconspicuously laciniate apex (Fig. 7F). Scleria scabra resembles $S$. cyperina (see the comment for $S$. cyperina above).

Distribution and habitat: Cuba, Guyana, Suriname, French Guiana, Venezuela, Bolivia, Colombia, Peru, and Brazil. In Brazil, it is recorded for the Northern (AM, RR, $\mathrm{PA}, \mathrm{RO}$, and TO), Northeastern (MA, PI, PB, AL, SE, and BA), Central-Western (MT, GO, and MS), and Southeastern (MG, ES, RJ, and SP) regions. In the state of Pará, it can be found growing in "campinas" and savannas.

22. Scleria secans (L.) Urb., Symb. Antill.: 2(2): 169. 1900. $\equiv$ Schoenus secans L., Syst. Nat. (ed. 10) 2: 865. 1759.

(Figs. 1E, 2A, 7G)

Herbs $1-5 \mathrm{~m}$ tall, perennial, monoecious, climbing, solitary; rhizomes knotted. Stems $1.3-3 \mathrm{~mm}$ wide, glabrous or glabrescent, angles glabrous, armed. Leaf-sheaths 4.2-6.3 cm long, chartaceous or papyraceous, glabrescent to pubescent, unwinged, margins glabrous, armed or not; ligule surrounding the sheath, trichomes ca. $0.5 \mathrm{~mm}$ long, dense, golden. Contraligules ca. $2 \mathrm{~mm}$ long, acute, apex glabrous, membranous appendage 1-5 $\mathrm{mm}$ long. Leafblades $16.9-31.8 \times 0.2-0.5 \mathrm{~cm}$, linear, continuous to the sheath, abaxially glabrous or glabrescent, midrib armed, adaxially glabrous or puberulous with two armed ribs, midrib glabrous, unarmed, margins glabrous and armed, apex entire. Involucral bracts $3.5-10.5 \times 0.2-0.4 \mathrm{~cm}$, foliaceous, linear to lanceolate. Inflorescences $23-32 \times$ $1.5-3.5 \mathrm{~cm}$, paniculate; rachis pubescent, angles ciliate, and unarmed. Spikelets staminate and pistillate, in the same panicle. Staminate spikelets $1.9-3.5 \times 0.9-1 \mathrm{~mm}$, narrowellipsoid to lanceoloid, pedicellate; pedicel 1.2-3.2 $\mathrm{mm}$ long. Pistillate spikelets $4.5-5.3 \times 0.8-1.5 \mathrm{~mm}$, lanceoloid, subsessile to pedicellate; pedicel $0.5-1 \mathrm{~mm}$ long. Glumes light brown to dark vinaceous, glabrous, midrib glabrous, armed, margins glabrous, apex mucronate. Stamens 3 per flower. Nutlets 3.2-3.4 × 2.5-2.6 mm, ovoid, subcircular in cross-section, white, surface smooth, glabrous, rarely puberulous, base lacking pores, apex rounded, sometimes obtuse. Stylobase absent. Hypogynium developed, annular rarely obscurely trilobed, lobes absent rarely rounded, light brown, margin revolute, apex entire. Cupules concave, entire to obscurely trilobed, persisting at the rachilla, margin glabrous.

Examined material: BRAZIL. PARÁ: Acará, GuajaráMiri, ca. 14 km da PA-483, 1³1'57.7” S, 48²0'46.5” W, 28/III/2018, fl. and fr., Schneider, L. \& Harley, R. 171 (MG); Altamira, Margem direita do Rio Xingu, confluência com rio Pardo, 14/X/86, fl. and fr., Vasconcelos, R.T.P. et al. 287 (INAP, MG); Belém, Beira de capoeira, 157 L. IAN, 21/VIII/1950, fl. and fr., Black, G.A. 50-10062 (IAN); Bragança, península de Ajuruteua, Salinas dos Roques/Jabuti, 0 55'36" S, 46 40'12" W, 22/V/2005, fl. and fr., Nascimento, R.E.S.A. 258 (HBRA); Canaã dos Carajás, Floresta Nacional de Carajás, Serra SullS11D, trilha para lagoa do amendoim, mata baixa de canga, $6^{\circ} 23^{\prime} 65^{\prime \prime}$ S, 50 $22^{\prime} 29^{\prime \prime} \mathrm{W}, 1 / \mathrm{XII} / 2015$, fl. and fr., Praia, T.S. et al. 26 (MG); Itaituba, Rio Tapajós-Canta Galo-Terra Preta, 548'56" S, 57²3'34" W, 21/X/2012, fl. and fr., Amaral, I.L. et al. 3474 (INPA); Melgaço, Floresta Nacional de Caxiuanã, Estação Científica Ferreira Penna, Baia de Caxiuanã entre Igarapé Curuá e Campinho, $1^{\circ} 45^{\prime} 6^{\prime \prime}$ S, 51 23'23” W, 22/ IV/17, fl. and fr., Schneider, L. et al. 84 (MG); Mojú, Fábrica, mata atraz da casa, 31/V/1954, fl., Black, G.A. 54-16240 (IAN); Monte Alegre, Ramal Água Preta, 16/II/1997, fl. and fr., Silva, M.F.F. et al. 2473 (MG); Oriximiná, Mineração Rio do Norte, Porto Trombetas, Mina Sacará, 1999, fl. and fr., Barbosa, E. et al. 278 (HSTM); Parauapebas, FLONA de Carajás, Serra dos Carajás, Serra Norte, estrada entre N4 (WS) e N, interior de floresta ombrófila, 6 6'19" S, 50¹1'01' W, 3/IX/2015, fl., Gil,A. et al. 520 (MG); Santarém, Alter do Chão, 2/VII/1982, Blanch, L.C. 173 (INPA); Vigia, PA 140, $1^{\circ} 0^{\prime} 49^{\prime \prime}$ S, 48 7'48.8” W, 4/IX/2017, fl. and fr., Silva, F.A. \& Viana, P.L. 238 (MG); n.1., 075'00” S, 52³0’00” W, 12/ IX/1987, fl. and fr., Beck, H.T. et al. 49 (INPA); Rio Capim ad Acaputeua, 18/II/1882, fl. and fr., Schwacke 40116 (RB).

Comment: Scleria secans is characterized by its climbing growth that forms large tangles at forest edges and clearings (Fig. 1E), unwinged leaf-sheaths, conspicuously armed and very sharp leaf-blades margins; paniculate inflorescences with few branches and spikelets (Fig. 2A), annular hypogynium (Fig. 7G), ovoid nutlet with a smooth and glabrous surface, rarely puberulous (Fig. 7G). This species can be confused with others occurring in the study area, such as S. flagellum-nigrorum and S. vaginata Steud. (see the comment for S. flagellum-nigrorum). Scleria secans 
and $S$. vaginata share the climbing habit, ovoids and white nutlets, and annular hypogynium (Fig. 7G, M). However, $S$. secans presents unwinged leaf-sheaths (vs. winged), present contraligule's membranous appendage (vs. absent in $S$. vaginata), and inflorescences $1.5-3.5 \mathrm{~cm}$ wide $(v s .7-13 \mathrm{~cm}$ wide). In a single specimen (Schneider, L. et al. $162-\mathrm{MG}$ ), we observed the occurrence of galls, which are similar to those found in S. bracteata. These galls affected the hypogynium's development, leaving it deformed (see the comment for S. bracteata).

Distribution and habitat: Northeastern and southeastern Mexico, Belize, Costa Rica, Guatemala, Honduras, Nicaragua, Panama, Cuba, Dominican Republic, Haiti, Jamaica, Puerto Rico, Trinidad and Tobago, Guyana, Suriname, French Guiana, Venezuela, Bolivia, Colombia, Ecuador, Peru, Brazil, and Argentina. It is recorded for all Brazilian States. In the state of Pará, it occurs in forest edges and clearings, riparian forests, "restingas", "campos rupestres", and anthropized environments.

23. Scleria sprucei C.B.Clarke, Bull. Misc. Inform., Addit. Ser.8: 61. 1908.

(Figs. 5B, 7H)

Herbs ca. $1.5 \mathrm{~cm}$ tall, perennial, monoecious, erect, solitary; rhizomes not seen. Stems ca. $6 \mathrm{~mm}$ wide, glabrous, angles glabrous, unarmed. Leaf-sheaths $7-11 \mathrm{~cm}$ long, chartaceous, glabrous, winged, wings $0.5-5 \times 0.05-0.4 \mathrm{~cm}$, sometimes inconspicuous, margins glabrous, unarmed; ligule absent. Contraligules $0.7-1.5 \mathrm{~mm}$ long, acute, apex glabrous, membranous appendage absent. Leaf-blade $25-41 \times 6.5-9.1 \mathrm{~cm}$, oblong, continuous to the wings of the sheaths, abaxially glabrous, midrib armed toward the apex, rare entirely unarmed, adaxially glabrous, midrib glabrous, unarmed, margins glabrous and armed toward the apex, apex pseudopremorse. Involucral bracts $10.5-24.7$ $\times 1.5-6.2 \mathrm{~cm}$, foliaceous, linear. Inflorescences ca. $34 \times$ $8 \mathrm{~cm}$, paniculate; rachis puberulous, angles ciliate, and unarmed. Spikelets staminate and subandrogynous, in the same panicle. Staminate spikelets ca. $4.5 \times 1.7-1.8$ $\mathrm{mm}$, lanceoloid, sessile to pedicellate; pedicel up to $2 \mathrm{~mm}$ long. Subandrogynous spikelets $3.6-3.9 \times 1.2-1.7 \mathrm{~mm}$, lanceoloid, pedicellate; pedicel 1-1.4 mm long. Glumes light brown with red lines, glabrous to puberulous, midrib glabrous, armed, margins ciliolate, apex mucronate. Stamens 3 per flower. Nutlets $5.5-5.7 \times 4.5-4.7 \mathrm{~mm}$, ovoid, circular in cross-section, yellowish-brown, surface smooth, glabrous, base lacking pores, apex rounded. Stylobase ca. $1.5 \mathrm{~mm}$ long, terete, light brown, deciduous. Hypogynium developed, trilobed, lobes rounded, light brown, margin flat, apex entire. Cupules concave, trilobed, persisting at the nutlet, margin ciliolate, trichomes $0.1-0.2 \mathrm{~mm}$ long, hyaline.

Selected material: BRAZIL. PARÁ: Novo Progresso, Serra do Cachimbo, Campo de Prova Brigadeiro Vellozo,
9²3'59.8” S, 545ㄴ'55.4" W, 03/X/2019, fl. and fr., Schneider, L. et al. 438 (MG).

Comment: Scleria sprucei has oblong leaf-blades with pseudopremorse apex, paniculate inflorescences (Fig. 5B), ovoid nutlets with a smooth and glabrous surface, deciduous stylobase, and ciliolate cupules persisting at the fruit (Fig. $7 \mathrm{H})$. This species differs from the remaining ones recorded for the study area, mainly by its oblong leaf-blades, which are far less common in this genus (often lanceolate to linear leaf-blades). The conspicuously pseudopremorse leaf-blade apex is a diagnostic feature in this species. Despite these characteristics, this species can be confused with $S$. macrophylla (see the comment of S. macrophylla).

Distribution and habitat: Venezuela, Bolivia, and Brazil. In Brazil, recorded for the Northern (AC, AM, RR, $\mathrm{PA}$, and RO) and Central-Western (MT) regions. In the state of Pará, it grows in savannas and anthropized areas.

24. Scleria stipularis Nees, J. Bot. (Hooker) 2: 394. 1840.

(Figs. 5C, 7I)

Herbs 1-2 m tall, perennial, monoecious, erect, solitary; rhizomes knotted. Stems $0.5-1 \mathrm{~cm}$ wide, glabrous or glabrescent, angles glabrous, armed. Leaf-sheaths 8.6-11.6 cm long, chartaceous, glabrous to pubescent, unwinged, margins glabrous, armed or not; ligule absent. Contraligules $0.6-1.1 \mathrm{~mm}$ long, acute to rounded, apex glabrous, membranous appendage $0.8-2.5 \mathrm{~cm}$ long. Leafblades $60-82.4 \times 2.7-3.3 \mathrm{~cm}$, linear, continuous to the sheath, abaxially glabrous, midrib armed, adaxially glabrous with two armed ribs toward the apex, midrib puberulous, margins glabrous and armed, apex entire. Involucral bracts $7-20.8 \times 0.9-3 \mathrm{~cm}$, foliaceous, linear. Inflorescences $6.5-$ $28 \times 4-9.2 \mathrm{~cm}$, paniculate; rachis glabrous, angles glabrous, and armed. Spikelets staminate and pistillate, in the same panicle. Staminate spikelets $4.2-6.3 \times 0.5-0.7 \mathrm{~mm}$, terete, subsessile; pedicel ca. $0.5 \mathrm{~mm}$ long. Subandrogynous spikelets $5.5-6.3 \times 1-1.8 \mathrm{~mm}$, terete, subsessile to pedicellate; pedicel $0.5-1 \mathrm{~mm}$ long. Glumes light brown with vinaceous margins, glabrous, midrib glabrous, unarmed, margins glabrous, apex mucronate to apiculate (3rd staminate glume apiculate). Stamens 3 per flower. Nutlets $3.2-3.8 \times 2-2.8 \mathrm{~mm}$, ovoid, subtriangular in crosssection, white to black, surface rugulose, puberulous, base lacking pores, apex acute or attenuate. Stylobase absent. Hypogynium developed, trilobed, lobes triangular, light brown, margin revolute, apex entire or laciniate. Cupule concave, entire, persisting at the rachilla, margin glabrous.

Examined material: BRAZIL. PARÁ: Almeirim, Distrito de Monte dourado, área de manejo da Orsa Florestal, $1^{\circ} 09^{\prime} 48^{\prime \prime}$ S, 52 $37^{\circ} 35^{\prime \prime} \mathrm{W}, 31 / \mathrm{VI} / 2010$, fl. and fr., Forzza, R.C. \& Leal, E.S. 5924 (MG, RB); Altamira, km 8 da estrada Transamazonica, no rumo de Marabá, igarapé Trindade, $3 /$ VIII/1971, fl. and fr., Cavalcante, P. \& Silva, M. 2860 (MG); 
Breu Branco, approx. $40 \mathrm{~km} \mathrm{~S}$ of Tucurui, then $5 \mathrm{~km}$ on old longing road., 403'00" S, 4940'00" W, 16/XI/1981, fl. and fr., Daly, D.C. et al. 1381 (INPA, MG); Oriximiná, Rio caxipacoro, $\mathrm{km} 72$ on the road north of cachoeira Porteira, 31/VI/1980, fl. and fr., Davidson, C. \& Martinelli, G. 10654 (INPA, RB).

Comment: Scleria stipularis is characterized by its unwinged leaf-sheaths, contraligules with a membranous appendage, pyramidal paniculate inflorescences (Fig. 5C), third male glume with apiculate apex, ovoid nutlets with a rugulose and puberulous surface (Fig. 7I), and trilobed hypogynium with triangular lobes (Fig. 7I).

Distribution and habitat: Guyana, Suriname, French Guiana, Venezuela, Bolivia, Colombia, Peru, and Brazil. In Brazil, it is recorded for the Nothern (AC, AM, RR, and PA) and Northeastern (MA) regions. In the state of Pará, it occurs in forest edges, "igapós", and anthropized environments.

25. Scleria tenacissima (Nees) Steud., Syn. Pl. Glumac. 2: 175. 1855. =Omoscleria tenacissima Nees, Fl. Bras. 2(1): 181. 1842.

(Figs. 5D, E, 7J)

Herbs, hight not seen, perennial, dioecious, climbing, solitary; rhizomes not seen. Stems $1.8-2.5 \mathrm{~mm}$ wide, glabrous to pubescent, angles glabrous, armed or not. Leaf-sheaths $1.6-5.3 \mathrm{~cm}$ long, chartaceous, glabrous to pubescent, unwinged, margins glabrous, armed; ligule surrounding the sheath, trichomes $0.3-0.5 \mathrm{~mm}$ long, dense, light brown. Contraligules $1-2 \mathrm{~mm}$ long, acute, apex ciliate or glabrous, unarmed, membranous appendage absent. Leaf-blades $8.3-25.1 \times 0.2-0.5 \mathrm{~cm}$, linear to lanceolate, continuous to the sheath, abaxially glabrous, midrib armed, adaxially glabrescent, midrib puberulous, margins glabrous and armed, apex entire. Involucral bracts 2-19.7 × 0.1-0.4 cm, foliaceous, lanceolate. Inflorescences 2.4-14.3 $\times 1.5-3.5 \mathrm{~cm}$, paniculate; rachis pubescent, angles glabrous, and armed. Spikelets staminate or pistillate, in the distinct specimens. Staminate spikelets $3.5-5.5 \times$ 1.2-1.6 mm, lanceoloid, sessile to subsessile; pedicel up to $0.5 \mathrm{~mm}$ long. Pistillate spikelets $3-4.5 \times 0.6-1 \mathrm{~mm}$, lanceoloid, subsessile to pedicellate; pedicel up to $1 \mathrm{~mm}$ long. Glumes light brown to reddish-brown, glabrescent, midrib pubescent, unarmed, margins glabrous to ciliolate, apex mucronate. Stamens 3 per flower. Nutlets 2.5-3.2 × 2-2.1 $\mathrm{mm}$, globose to subglobose, subcircular in cross-section, white, surface crested-reticulate, glabrous, base lacking pores, apex apiculate. Stylobase absent. Hypogynium developed, annular, lobes absent, light brown to yellowish, margin revolute, apex entire. Cupules flat, entire, persisting at the rachilla, margin glabrous.

Examined material: BRAZIL. PARÁ: Altamira, lado esquerdo a jusante do Rio Xingu, no lago da Ilha do Muruci, 19/X/1986, fl., Dias, A.T.G. 368 (MG); Belterra, beira do lago Jurucuí, 24/X/1947, fl., Black, G.A. 47-1779 (IAN);
Faro, Rio Jacundá, praia Porto Rico, 15/XI/1950, fl., Black, G.A. 50-10799 (IAN); Santarém, Alter do Chão, lago verde, $2^{\circ} 28^{\prime} 20^{\prime \prime}$ S, 54 $4^{\circ} 55^{\prime} 42^{\prime \prime}$ W, 22/III/2016, fl. and fr., Mortati, A.F. et al. 40 (HSTM, INPA, RB).

Comment: Scleria tenacissima is dioecious, presents a climbing habit, unwinged and ligulate leaf-sheaths, paniculate inflorescences with staminate (Fig. 5D) or pistillate spikelets (Fig. 5E), globose nutlets with a crestedreticulate and glabrous surface, and annular hypogynium (Fig. 7J). The inflorescences develop from nodes in the midportion of the stem, such as buds (Fig. 5D), which is unique in Scleria. The inflorescence-bearing nodes are the commonly collected structure. Thus, the underground system was not observed. Further, this information was not found in the literature or consulted herbaria specimens. This species resembles $S$. amazonica (see the comment for S. amazonica).

Distribution and habitat: Venezuela, Bolivia, and Brazil. In Brazil, it is solely recorded for the Northern (AM, $\mathrm{RR}$, and PA) region. In the state of Pará, it occurs in "várzeas" and riparian forests.

26. Scleria tenella Kunth, Enum. Pl. 2: 353. 1837. (Figs. 2B, 7K)

Herbs $18.5-40.5 \mathrm{~cm}$ tall, annual, monoecious, erect, caespitose or solitary; rhizomes absent. Stems $0.4-1 \mathrm{~mm}$ wide, glabrous, angles glabrous, unarmed. Leaf-sheaths $1-3.6 \mathrm{~cm}$ long, membranous, glabrous to pubescent, unwinged, margins glabrous, unarmed; ligule absent. Contraligules up to $0.7 \mathrm{~mm}$ long, concave to acute, apex ciliate, membranous appendage $0.2-0.5 \mathrm{~mm}$ long. Leafblades $8-17.7 \times 0.1-0.2 \mathrm{~cm}$, linear, continuous to the sheath, abaxially glabrous, midrib armed toward the apex, adaxially glabrous, sometimes with two armed ribs, midrib glabrous, unarmed; margins glabrous and unarmed or armed toward the apex, apex entire. Involucral bracts $0.1-3 \times$ $0.05-0.1 \mathrm{~cm}$, glumaceous, lanceolate. Inflorescences $3-12$ $\times 1-2 \mathrm{~cm}$, spiciform, branched or not; rachis glabrous, angles ciliate or armed. Spikelets androgynous $2.1-3.3 \times 0.6-1$ $\mathrm{mm}$, terete to lanceoloid; sessile to subsessile, pedicel up to $0.5 \mathrm{~mm}$ long. Glumes reddish-brown to dark vinaceous and midrib green, glabrous, midrib glabrous, armed, margins glabrous, apex mucronate. Stamen 1 per flower. Nutlets $0.9-1.4 \times 0.6-1.1 \mathrm{~mm}$, subglobose, subtriangular in crosssection, white to greyish, surface crested-reticulate to slightly reticulate, sometimes papillose, glabrous, base with 12-15 pores, rarely lacking pores, apex apiculate. Stylobase absent. Hypogynium reduced, light brown. Cupules flat, trilobed, persisting at the rachilla, margin glabrous.

Examined material: BRAZIL. PARÁ: Cachoeira do Arari, Rodovia km15, 054'30.4" S, 4840’5.8” W, 20/ IX/2017, fl. and fr., Schneider, L. \& Silva, F.A. 154 (MG); Cametá, estrada Juaba-Cametá a cerca de 2,5 km de Juaba com estrada cruzando Campo de Natureza, $02^{\circ} 22^{\prime} 20^{\prime \prime} \mathrm{S}$, 49³3'57" W, 6/VII/2017, fl. and fr., Gil, A. et al. 804 (MG); 
Canaã dos Carajás, Corpo B Floresta Nacional de Carajás, 6²0'39" S, 50²5'20" W, 16/II/2010, fl. and fr., Costa, L.V. 780 (HCJS); Magalhães Barata, Sítio Vila Nova, antiga estrada para o Km 40 do Mocoóca, 18/XII/2002, fl. and fr., Oliveira, J. et al. 620 (MG); Maracanã, campo da mangaba, 23/VI/2009, fl. and fr., Rocha, A.E.S. 1071 (MG); Portel, comunidade Santa Rosa, 150'28” S, 50³8'9.7” W, 1/ VI/2016, fl. and fr., Silva, C.A.S. 464 (MG); Salvaterra, Água Boa, 051'3.8” S, 48³1'19.7” W, 21/IX/2018, fl. and fr., Schneider, L. 156 (MG); São Geraldo do Araguaia, Trilha da Casa de Pedra, rumo a cachoeira quarta queda, 06 $09^{\prime} 56.7^{\prime \prime}$ S, 48 33'31.8" W, 6/VII/2018, fl. and fr., Schneider, L. et al. 238 (MG); n.l., Marajó, Jutubi, campos altos arenoso, 2/VII/1902, fl. and fr., Huber, J. (MG2727); Marajó, Rio Camará, Jutuba, IX/1902, fl. and fr., Miranda, V.C. 3092 (IAN, INPA, MG); Rio Tiriós, lado esquerdo, parte norte ocidental do Estado do Pará, 21/V/1962, fl. and fr., Oliveira, S. 1991 (IAN); Serra do Cachimbo, 16/XII/1956, fl. and fr., Pires, J.M. et al. 6329 (IAN).

Comment: Scleria tenella is characterized by the inconspicuous contraligule membranous appendage, glabrous leaf-blades, glumaceous involucral bracts, branched or not spiciform inflorescences (Fig. 2B), glabrous glumes with an inconspicuously armed midrib, staminate flowers with one stamen, and subglobose nutlets with a crestedreticulate to inconspicuously reticulate, sometimes papillose surface (Fig. 7K). This species resembles S. burchellii, $S$. interrupta, S. pusilla, and S. sp., which occurs in the state of Pará (see the comments for each species). Scleria tenella presents the diagnostic nutlet with ornamentation and pores at the base. Some specimens did not present pores at the base, instead of exhibiting depressions (Gil, A. et al. 804 - MG; Silva, C.A.S. \& Albernaz, A.L.K.M. 464 - MG; and Oliveira, J. $620-M G$ ). In S. tenella, the nutlet base can sometimes present pores or not, in the same inflorescence. This variation of the nutlet base was also observed by Camelbeke \& Goetghebeur (1998). In the studies of the South American Scleria, the name S. tenella was sporadically applied, sometimes treated as a synonym of $S$. verticillata, due to similarities in habit, leaves, inflorescences, and nutlet morphology (Core 1936; Camelbeke et al. 2002). In the Scleria treatment for the Flora of the Venezuelan Guyana, Camelbeke \& Goetghebeur (1999) cites the similarities between $S$. verticillata and S. tenella. Despite citing several characters, the authors still chose to treat both species in a broad sense, accepting S. verticillata as the correct name. In Brazil, most floras (Mendes et al. 2010; Nunes \& Prata 2013; Nunes et al. 2016; Araújo \& Trevisan 2018) only recognize $S$. verticillata, treating $S$. tenella as a mere synonym. However, the recent nomenclatural review and phylogenetic study of $S$. subg. Hypoporum (Bauters et al. 2018; Bauters et al. 2019), revealed that they are distinct species. Scleria verticillata s.lat. was distributed from the United States to Brazil. Nonetheless, S. verticillata s.str. is restricted to North America, while S. tenella ranges from Mexico to Brazil (Bauters et al. 2019). They are morphologically distinguished by their spikelets and nutlet length, and nutlet ornamentation. Scleria tenella spikelets are 2-3 $\mathrm{mm}$ long (vs. 3-5 $\mathrm{mm}$ long in S. verticillata), while its nutlet are 1-1.5(-1.9) $\mathrm{mm}$ long (vs. ca. $1 \mathrm{~mm}$ long), with a fenestrated-verrucous surface (vs. transversely tuberculate) (Bauters et al. 2019).

Distribution and habitat: Southeastern Mexico, Belize, Costa Rica, El Salvador, Guatemala, Honduras, Nicaragua, Panama, Cuba, Guyana, Suriname, French Guiana, Venezuela, Bolivia, Colombia, and Brazil. In Brazil, it is recorded for the Northern (AC, AM, RR, AP, PA, TO, and $\mathrm{RO}$ ), Northeastern (MA, PI, SE, and BA), Central-Western (MT and GO), Southeastern (MG and SP), and Southern (PR) regions. In the state of Pará, it grows in "capoeiras" and savannas.

27. Scleria triquetra M.T.Strong, Novon 4(3): 300302. 1994.

(Figs. 5F, 7L)

Herbs 45.2-68 m tall, perennial, monoecious, erect, solitary; rhizomes unknotted. Stems $1-2.4 \mathrm{~mm}$ wide, glabrescent to pubescent, angles glabrous, armed. Leafsheaths $1.5-8.5 \mathrm{~cm}$ long, papyraceous, pubescent to puberulous, unwinged, margins glabrous, armed or not; ligule absent. Contraligules $2.8-5.5 \mathrm{~mm}$ long, acute, apex ciliate, unarmed, membranous appendage absent. Leaf-blades $11.6-27.5 \times 0.3-0.7 \mathrm{~cm}$, linear, continuous to the sheath, abaxially pubescent, midrib armed, adaxially glabrous or puberulous, with two armed ribs, midrib glabrous, unarmed, margins glabrous and armed, apex entire. Involucral bracts $3-7.6 \times \mathrm{ca} .0 .1 \mathrm{~cm}$, lanceolate, foliaceous. Inflorescences 3.5-7.5 × 2-6.2 cm, paniculate; rachis puberulous or pubescent, angles ciliate or not, and armed. Spikelets staminate and subandrogynous, in the same panicle. Staminate spikelets $4.5-6 \times$ 1.3-1.5 mm, terete, pedicellate; pedicel 1.5-5(-32) $\mathrm{mm}$ long. Subandrogynous spikelets $5.3-6.1 \times 1-1.7 \mathrm{~mm}$, lanceoloid, pedicellate; pedicel 1-1.5 mm long. Stamen 1 per flower. Glumes light brown to reddish-brown with vinaceous margins, puberulous, midrib glabrous, unarmed, margins ciliolate, apex mucronate. Nutlets 3.3-3.8 × 2.8$3.1 \mathrm{~mm}$, ovoid, subtriangular in cross-section, white to light brown with gray lines, surface smooth and crested at the angles, pubescent, base lacking pores, apex apiculate. Stylobase absent. Hypogynium developed, trilobed, lobes rounded, light brown, margin revolute, apex entire. Cupules concave, trilobed, persisting at the rachilla, margin glabrous.

Examined material: BRAZIL. PARÁ: Itaituba, Baixo Tapajós, Vila Canaã, margem esquerda do rio, $05^{\circ} 03^{\prime} 22^{\prime \prime}$ S, 56 ${ }^{\circ}$ '1'38" W, 2/V/2013, fl. and fr., Amaral, L.L. et al. 3643 (INPA); Santarém, Rurópolis km 103, 03¹5'00" S, $55^{\circ} 00^{\prime} 00^{\prime \prime} \mathrm{W}, 21 / \mathrm{I} / 1976$, fl. and fr, s.c. s.n. (RB242177); Porto Trombetas, Mineração Rio Norte, mina Saracá, 
1999, fl. and fr., Barbosa, E.M. et al. 256 (INPA); n.1., Rio Jarí, estrada do Caracurú, 8/I/1969, fl. and fr., Nilo T. Silva 1581 (IAN); Estrada de Munguba Km 14, 16/VI/1969, fl. and fr., Nilo T. Silva 2199 (IAN).

Comment: Scleria triquetra can be differentiated by its unwinged and not ligulate leaf-sheaths, leaf-blades adaxially pubescent, paniculate inflorescences (Fig. 5F), ovoid nutlets with smooth and crested angles, and a pubescent surface, and trilobed hypogynium with revolute margin (Fig. 7L). Strong (1994) distinguished S. triquetra, by the presence of a concave-sided nutlet, which was not observed in the other species of the Scleria subg. Scleria sect. Scleria that occurs in the neotropics.

Distribution and habitat: French Guiana and Brazil. In Brazil, it is exclusively recorded for the Northern (AM and PA) region. In the state of Pará, it occurs at forest edges and clearings, and riparian forests.

28. Scleria vaginata Steud., Syn. Pl. Glumac.2: 179. 1855.

(Figs. 5G, 7M)

Herbs ca. $2.5 \mathrm{~m}$ tall, perennial, monoecious, climbing, solitary; rhizomes not seen. Stems $4.6-5 \mathrm{~mm}$ wide, glabrous, angles glabrous, armed. Leaf-sheaths $9.9-10.5 \mathrm{~cm}$ long, chartaceous, glabrous, winged, wings 9.8-10.3 × 0.3-0.5 $\mathrm{cm}$, margins glabrous, armed; ligule surrounding the sheath, trichomes $0.2-0.4 \mathrm{~mm}$ long, dense, golden. Contraligules 6-9 mm long, acute, apex glabrous, membranous appendage absent. Leaf-blades $60-75.7 \times 1-1.1 \mathrm{~cm}$, linear, continuous to the sheath, abaxially glabrous, midrib armed, adaxially glabrous with two armed ribs, midrib glabrous, unarmed, margins glabrous and armed, apex entire. Involucral bracts 36.8-43.5 × ca. $1 \mathrm{~cm}$, foliaceous, linear. Inflorescences 24.8-39 × 7-13 cm, paniculate; rachis pubescent or puberulous, angles glabrous, and armed. Spikelets staminate and pistillate, in the same panicle. Staminate spikelets $4.2-5.7 \times 0.6-0.7 \mathrm{~mm}$, lanceoloid, subsessile or pedicellate; pedicel $0.4-6.2 \mathrm{~mm}$ long. Pistillate spikelets 8-9.5 × 1-1.5 mm, narrow-ellipsoid or lanceoloid, sessile. Glumes light brown and vinaceous margins to totally dark brown, glabrous to puberulous, midrib glabrous, unarmed, margins glabrous, apex mucronate. Stamens 3 per flower. Nutlets $3.5-4 \times$ ca. $2.5 \mathrm{~mm}$, ovoid, circular in cross-section, ivory to grayish, surface smooth, glabrous, base lacking pores, apex rounded. Stylobase absent. Hypogynium developed, annular, lobes absent, light brown, margin flat, apex entire. Cupules concave, entire, persisting at the rachilla, margin glabrous.

Examined material: BRAZIL. PARÁ: Canaã dos Carajás, Floresta Nacional de Carajás, Serra Sul-S11D, 6²2'24" S, 50²1'10" W, 3/XII/2015, fl. and fr., Nunes, C.S. et al. 94 (MG); Parauapebas, Floresta Nacional de Carajás, mina do Alemão, 6¹'2.7" S, 50³4'58.3” W, 5/XII/2017, fl. and fr., Schneider, L. et al. 161 (MG).
Comment: Scleria vaginata presents a climbing habit, conspicuously winged and ligulate leaf-sheaths, contraligule without a membranous appendage, armed leaf-blades with entire apex, and erect inflorescences with patent to ascending branches (Fig. 5G). The inflorescences are composed of unisexual spikelets, and the nutlets are ovoid with a smooth and glabrous surface, while the hypogynium is annular (Fig. 7M). At first sight, the examined specimens were determined as Scleria poeppigii (Nees) Steud., due to its climbing habit, winged leaf-sheaths, armed leaf-blades with entire apex. Furthermore, it presents Hymenolytrumtype inflorescence (i.e., pistillate spikelets at the base of the branches and staminate spikelets at the apex of secondary branches). Finally, when describing Hymenolytrum poeppigii, Nees (1842), cites the inflorescence branches as pubescent, which also matches the specimens form the state of Pará.

Nonetheless, when analyzing the negative of the type specimen of S. poeppigii (Poeppig 2354 - B31272) at the Natural History Field Museum, we noticed that the inflorescences are flexible, with patent branches. These characteristics do not match the specimens from Pará treated as S. poeppigii by us. Scleria tonduzii Boeck. represents a heterotypic synonym of $S$. vaginata, which is confirmed by Core (1936), who analyzed its isotype (Tonduz 8181 - US). Based on the description of $S$. vaginata presented by Core (1936), it became possible to observe similarities, such as erect inflorescences and patent to ascending branches, to the specimens from the state of Pará. After considering the aforementioned information, we concluded that the entity previously treated by us as $S$. poeppigii actually represents $S$. vaginata. However, due to our impossibility to personally analyze the type specimens, further studies are still necessary to clarify the boundaries between these two species.

Distribution and habitat: Costa Rica, Panama, Suriname, Venezuela, Bolivia, Colombia, Ecuador, Peru, and Brazil. In Brazil, S. vaginata is currently only recorded for the state of Pará and Bahia, representing the first record for Pará and the Northern region. In the state of Pará, it can be found growing at forest edges.

29. Scleria violacea Pilg., Bot. Jahrb. Syst. 30(1): 145. 1901.

(Figs. 2C, 7N)

Herbs $0.5-1.5 \mathrm{~m}$ tall, perennial, monoecious, erect or climbing, solitary; rhizomes knotted. Stems 2-7 mm wide, glabrous, angles glabrous, armed or not. Leafsheaths $5.1-12.8 \mathrm{~cm}$ long, papyraceous or chartaceous, glabrous, basal ones unwinged, distal ones winged, wings $3-8.2 \times 0.05-0.2 \mathrm{~cm}$, margins glabrous, armed or not; ligule surrounding the sheath, trichomes ca. $1 \mathrm{~mm}$ long, dense, golden. Contraligules $0.5-1 \mathrm{~cm}$ long, acute to rounded, apex glabrous, membranous appendage 0.3$1.7 \mathrm{~cm}$ long. Leaf-blades $11-53.1 \times 0.7-1.5 \mathrm{~cm}$, linear, 
continuous to the sheath, abaxially glabrous, midrib armed, adaxially glabrous with two armed ribs, midrib glabrous to puberulous, armed, margins glabrous and armed, apex entire. Involucral bracts $3-12(-20) \times 0.2-1.2 \mathrm{~cm}$, foliaceous, linear to lanceolate. Inflorescences $6.9-7.5$ $\times 5.5-7.6 \mathrm{~cm}$, paniculate; rachis glabrous to puberulous, angles ciliate or not, and armed. Spikelets staminate and pistillate, in the same panicle. Staminate spikelets 3.6-5.7 × 0.4-1.3 mm, lanceoloid, sessile to pedicellate; pedicel up to $6.3 \mathrm{~mm}$ long. Pistillate spikelets $5.2-8 \times$ $0.7-1.3 \mathrm{~mm}$, lanceoloid, pedicellate; pedicel 1-4(-7) $\mathrm{mm}$ long. Glumes dark vinaceous to light brown with vinaceous maculae, glabrous to puberulous, midrib glabrous, unarmed, margins glabrous, apex mucronate. Stamens 3 per flower. Nutlets $3-3.9 \times 1.8-2.5 \mathrm{~mm}$, ellipsoid to subglobose, subtriangular in cross-section, white to purple, surface smooth or rugulose, puberulous, base lacking pores, apex attenuate to apiculate. Stylobase absent. Hypogynium developed, trilobed, lobes triangular, light brown, margin revolute, apex entire. Cupules concave, entire, persisting at the rachilla, margin glabrous.

Examined material: BRAZIL. PARÁ: Acará, Fazenda CREA, gleba 2, 8/VI/1988, fl. and fr., Rodrigues, I.A 1388 (IAN); Augusto Corrêa, engenho, área de retirada de areia ao norte da Estrada Bragança-Augusto Corrêa (PA-454), aprox. $8 \mathrm{~km}$ de rua de Bragança ca. $1^{\circ} 03^{\prime} 00^{\prime \prime} \mathrm{S}, 46^{\circ} 40^{\prime} 00^{\prime \prime} \mathrm{W}$, 19/I/2013, fl. and fr., Silva, R.M. 262 (HBRA); Bragança, $7 \mathrm{~km}$ east of Bragança along road to Augusto Correa, ca. $1^{\circ} 03^{\prime} 00^{\prime \prime}$ S, 4640'00" W, 7/IV/1980, fl. and fr., Davidse, G. et al. 17980 (MG); Cametá, Estrada Cametá-Juaba, 02²0'06" S, 49³4'37" W, 6/VII/2017, fl. and fr., Gil, A. et al. 788 (MG); Colares, 16/VIII/1913, fl. and fr., Ducke, A. 12573 (MG); Conceição do Araguaia, $2 \mathrm{~km}$ west of town along highway PA-287, ca. $8^{\circ} 15^{\prime} 00^{\prime \prime}$ S, 49 $18^{\prime} 00^{\prime \prime} \mathrm{W}, 24 / \mathrm{II} / 1980$, fl. and fr., Plowman, T. et al. 9100 (MG, INPA); [Cumaru do Norte], Gorotire em volta da Aldeia, 25/VIII/1985, fl. and fr., Anne Gély 485 (MG); Jacareacanga, Region of the Village of Mouro, 2 hours by launch downstream from Missão Cururú, 7¹5'00" S, 5755'00" W, 18/II/1974, fl. and fr., Anderson, W.R. 11085 (IAN); Maracanã, Ilha de Algodoal, 22/V/2008, fl. and fr., Rodrigues, L.K.M. 13 (MG); Marapanim, Praia do Crispim, 0 36'8,9" S, 47 40'6” W, 2/V/2018, fl. and fr., Schneider, L. 183 (MG); Melgaço, Floresta Nacional de Caxiuanã, Estação Científica Ferreira Penna, próximo ao Igarapé Curuá, $1^{\circ} 46^{\prime} 42^{\prime \prime} \mathrm{S}, 5^{\circ} 25^{\prime} 30^{\prime \prime} \mathrm{W}, 22 / \mathrm{IV} / 2017$, fl. and fr., Schneider, L. et al. 92 (MG); Salvaterra, Joanes, 17/ IX/1976, fl. and fr., Rosa, N.A. et al. 942 (MG); São Geraldo do Araguaia, buritizal na beira de estrada, 27/VIII/2018, fl. and fr., Nunes, C.S. et al. 418 (MG); Tucuruí, $16 \mathrm{~km}$ of east of Represa Tucuruí (Rio Tocantins) along new road (PA-263), 345'00" S, 49³9'00" W, 30/VIII/1981, fl. and fr., Plowman, N.A. et al. 9750 (MG); Vigia, campina do Itajura, Ilha de colares, 28/IX/1954, fl. and fr., Black, G.A. 54-16845 (IAN); n.1., km 25 da estrada Tucuruí, repartimento, 30/ III/1981, fl. and fr., Rosa, N.A. et al. 4030 (MG); Campos a
E. de Faro, beira de muritizal, 19/II/1910, fl. and fr., Ducke, A. (MG10742); Margem esquerda do Rio Mojú, embocadura do Igarapé Jambuassú, 7/VII/1967, fl. and fr., Silva, M. 1016 (MG).

Comment: Scleria violacea presents climbing to erect habit, knotted rhizomes, ligulate leaf-sheaths, contraligule with a membranous appendage, pyramidal, paniculate and congested inflorescences (Fig. 2C), unisexual spikelets, ellipsoid to subglobose nutlet with a smooth or rugulose and puberulous surface, and a triangular hypogynium lobes with entire apex (Fig. 7N). The specimens of $S$. violacea in the consulted herbaria collection were initially identified as representing $S$. martii (see the comment for S. martii). However, S. violacea presents ligulate leaves, and hypogynium lobes with entire apex (vs. not ligulate leaves, and hypogynium lobes with laciniate apex). Scleria violacea can also be confused with $S$. comosa (Nees) Steud. and S. macrogyne, neither of them occurring in the state of Pará. Scleria violacea differs from S. comosa, mainly by its hypogynium lobes with entire apex (vs. laciniate in $S$. comosa). Alternatively, S. macrogyne can be differentiated by its leaf-sheaths conspicuously winged and $4-5 \mathrm{~mm}$ wide (vs. inconspicuously winged and $0.5-2 \mathrm{~mm}$ wide in S. violacea), and ovoid nutlets (vs. ellipsoid to subglobose). We recognize the need for further studies on $S$. subg. S. sect. Hymenolytrum, especially regarding the presence or absence of ligules in the leaves of its species. Furthermore, detailed and standardized descriptions, and ontogenic studies are needed to better circumscribe its species.

Distribution and habitat: French Guiana and Brazil. In Brazil, it is recorded for the Northern (PA and TO), Northeastern (MA, PI, and BA), and Central-Western (MT) regions. In the state of Pará, it occurs in "campinas", riparian forests, "igapós", savannas, and "restingas".

\section{Scleria sp. \\ (Figs. 5H, 7O)}

Herbs ca. $30 \mathrm{~cm}$ tall, annual, monoecious, erect, caespitose; rhizomes absent. Stems ca. $0.3 \mathrm{~mm}$ wide, glabrous, angles glabrous, unarmed. Leaf-sheaths ca. $3 \mathrm{~cm}$ long, membranous, pubescent, unwinged, margins glabrous, unarmed; ligule absent. Contraligules truncate to concave, apex glabrous, membranous appendage absent. Leaf-blades $15.1-15.4 \times$ ca. $0.1 \mathrm{~cm}$, linear, continuous to the sheath, abaxially glabrous, midrib armed toward the apex, adaxially glabrous, midrib glabrous, unarmed, margins glabrous and armed toward the apex, apex entire. Involucral bracts $4-5(-10) \times$ ca. $1 \mathrm{~mm}$, glumaceous, lanceolate. Inflorescences $9-9.8 \times 0.5-0.8 \mathrm{~cm}$, spiciform, unbranched; rachis glabrous, angles glabrous, and unarmed. Spikelets androgynous $3-3.2 \times 0.8-0.9 \mathrm{~mm}$, narrow-ellipsoid, sessile to subsessile; pedicel up to $0.5 \mathrm{~mm}$ long. Glumes light brown with midrib green, glabrous, midrib glabrous, armed, margins glabrous, apex mucronate. Stamens 2 per 
flower. Nutlets ca. $1 \times 1-1.3 \mathrm{~mm}$, obovoid, faces cordate, subtriangular in cross-section, white, surface crestedreticulate, glabrous, base reticulated, covered with brown tissue, apex obcordate. Stylobase absent. Hypogynium reduced, light brown. Cupules flat, trilobed, persisting at the rachilla, margin glabrous.

Examined material: BRAZIL. PARÁ: Redenção, 10-20/IV/2009, fl. and fr., Lobato, L.C.B. et al. 3612 (MG).

Comment: Scleria sp. is an annual herb, with leaves lacking the contraligule's membranous appendage, with glabrous leaf-blades, unbranched spiciform inflorescences (Fig. 5H), glabrous glumes with an inconspicuously scabrous midrib, staminate flowers with two stamens, obovoid nutlet with chordate faces, a crested-reticulate and glabrous surface, and a reticulate base covered by a brown tissue (Fig. 7O). It, most likely, represents a new species, but further collections are still needed to ascertain its identity. We place Scleria sp. in S. subg. H. sect. Hypoporum due to its spiciform inflorescences, androgynous spikelets, and reduced hypogynium. This species resembles $S$. tenella and $S$. afroreflexa Lye (the last native to Cameroon) due to their habit, inflorescences, and nutlet ornamentation. Scleria sp. differs from $S$. tenella, by lacking the contraligule's membranous appendage (vs. present), by having two stamens per flower (vs. one), obovoid nutlets with chordate faces (vs. subglobose), and a brown tissue covering the base of the nutlet ( $v s$. lacking a differentiated tissue). Scleria sp. differs from $S$. afroreflexa due to its leaf-blades margins which can be armed or not (vs. ciliate and unarmed in $S$. afroreflexa), inflorescences with erect fascicles (vs. reflexed), two stamens per flower (vs. three), and crested-reticulate nutlets with the base covered by a brown tissue (vs. reticulate with the base not covered by a differentiated tissue).

Distribution and habitat: Brazil. It is currently restricted to the state of Pará, Northern Brazil. It can be found growing in savannas.

\section{Acknowledgements}

We thank CNPq for the scholarship to LJCS (131573/2017-9), the Projects 455505/2014-4 (CNPq), 88881.159099/2017-01 (FAPESPA/CAPES), and the MPEG Research Support Program (PAP) for the financial support. We also thank to the curators of the consulted herbaria for access to their collections or information, and Dr. Kenneth Bauters for the relevant literature and his considerations on this study. This study was funded in part by the Coordenação de Aperfeiçoamento de Pessoal de Nível Superior (CAPES) - Financial Code 001.

\section{References}

Acevedo-Rodríguez P, Strong MT. 2012. Catalogue of Seed Plants of the West Indies. Smithsonian contributions to botany 98: 1-1192.
Adams C. 1994. Scleria. In: Davidse G, Sousa M, Chater AO. (eds.) Flora Mesoamericana. Vol. VI. Saint Louis, Missouri Botanical Gardens Press. p. 476-484.

Affonso R, Zanin A, Brummitt NA. 2015. Diversity of Scleria (Cyperaceae) in Santa Catarina, Brazil. Rodriguésia 66: 353-367.

Ahumada O. 2007. Las especies argentinas y paraguayas del Género Scleria P.J.Bergius (Cyperaceae). Estudio taxonómico y tipología de la sinflorescencia. PhD Thesis. Universidad Nacional del Litoral, Santa Fe, Argentina.

Ahumada O, Vegetti AC. 2009. Inflorescence structure in species of Scleria subgenus Hypoporum and subgenus Scleria (Sclerieae-Cyperaceae). Plant Systematics and Evolution 281:115-135.

Araújo AC. 2009. Scleria. In: Cavalcanti TB, Batista MF. (eds.) Flora do Distrito Federal. Vol. VII. Brasília, Embrapa. p. 125-153.

Araújo AC, Trevisan R. 2018. Cyperaceae da flora Sul-matogrossense: composição florística. Iheringia, Série Botânica 73: 190-200.

Barros M. 1960. Las Ciperaceas del Estado de Santa Catalina. Sellowia 12: $181-450$.

Bastos TX. 1982. O clima da Amazônia Brasileira segundo Köppen. Embrapa Amazônia Oriental-Pesquisas em andamento 87. https:// www.infoteca.cnptia.embrapa.br/infoteca/bitstream/doc/381629/1/ CPATUPA87.pdf

Bauters K, Asselman P, Simpson DA, Muasya AM, Goethghebeur P, Larridon I. 2016. Phylogenetics, ancestral state reconstruction, and a new infrageneric classification of Scleria (Cyperaceae) based on three DNA markers. Taxon 65: 444-466.

Bauters K, Goetghebeur P, Asselman P, Meganck K, Larridon I. 2018. Molecular phylogenetic study of Scleria subgenus Hypoporum (Sclerieae, Cyperoideae, Cyperaceae) reveals several species new to science. PLOS ONE 13: e0203478. doi: 10.1371/journal.pone.0203478

Bauters K, Larrindon I, Goetghebeur P. 2019. A taxonomic study of Scleria subgenus Hypoporum: synonymy, typification and a new identification key. Phytotaxa 394: 001-049.

BHL. 2019. Biodiversity Heritage Library. http://www.biodiversitylibrary. org/. 10 Dec. 2019.

Botanicus Digital Library. 2018. http://www.botanicus.org/. 22 Aug. 2018.

Cabrera Ziri V, Tillett SS. 2016. Glosario Morfológico del Indumento de Hojas y Tallos de Angiospermas en Venezuela. Acta Botánica Venezuélica 39: 37-65.

Camelbeke K. 2002. Morphology and taxonomy of genus Scleria (Cyperaceae) in Tropical South America. PhD Thesis, Universitat Ghent, Gent.

Camelbeke K, Goetghebeur P. 1998. Scleria. In: Berry PE, Yatskievych K, Holst BK. (eds.) Flora of the Venezuelan Guayana. Vol. IV. St. Louis, Missouri Botanical Garden Press. p. 641-659.

Camelbeke K, Goetghebeur P. 1999. The ligule, a new diagnostic character in Scleria (Cyperaceae). Systematics and Geography of Plants 69: 73-84.

Camelbeke K, Goetghebeur P. 2002. The genus Scleria (Cyperaceae) in Colombia. An updated checklist/el género Scleria (Cyperaceae) en Colombia. Una lista anotada. Caldasia 24: 259-268.

Camelbeke K, Strong MT, Goetghebeur P. 1997. Scleria amazonica, a new species of Scleria section Scleria (Cyperaceae) from Venezuela. Novon 7: 98-101.

Camelbeke K, Spruyt K, Goetghebeur P. 2003. The genus Scleria (Cyperaceae) in Bolivia. Revista de la Sociedad Boliviana de Botânica 4: 139-170.

Clarke CB. 1908. Scleria. Bulletin of Miscellaneous Information: Additional Series 8: 56-62.

Core EL. 1936. The american species of Scleria. Brittonia 2: 1-105.

Core EL. 1952. The genus Scleria in Brazil. Rodriguésia 15: 137-162.

Espinoza P, Chacón-Madrigal E, Sánchez E, Gómes-Laurito J. 2016. Key to the species of the genus Scleria (Cyperaceae) in Costa Rica based on the morphology of nutlets. Phytotaxa 284 : 81-107.

Flora do Brasil 2020. Jardim Botânico do Rio de Janeiro. http:// floradobrasil.jbrj.gov.br/. 01 Jun. 2021.

Furtado AMM, Ponte FC. 2013. Mapeamento de Unidades de Relevo do estado do Pará. Geoamazônia 2: 56-67.

Goetghebeur P. 1998. Cyperaceae. In: Kubitzki, K. The families and genera of vascular plants. 4th. edn. Berlin, Springer. p: 141-190. 
Gonçalves EG, Lorenzi H. 2011. Morfologia Vegetal: organografia e dicionário ilustrado de morfologia das plantas vasculares. 2nd. edn. São Paulo, Instituto Plantarum de Estudos da Flora.

Govaerts R. 2019. World Checklist of Scleria. Facilitated by the Royal Botanic Gardens, Kew. http://apps.kew.org/wcsp/namedetail. do?name_id=265158. 19 Aug. 2019.

Harris JG, Harris MW. 2001. Plant identifcacion terminology: An illustrated glossary. 2nd. edn. Spring Lake, Spring Lake Publishing.

Hennessy EFF. 1985. The genus Scleria in southern Africa. Bothalia 15: 505-530.

IBGE - Instituto Brasileiro de Geografia e Estatística. 2016. Estados. http:// www.ibge.gov.br/estadosat/perfil.php?lang=\&sigla=pa. 25 Aug. 2018.

IBGE - Instituto Brasileiro de Geografia e Estatística. 2004. Mapa de Vegetação do Brasil. Escala 1:5 000 000. Rio de Janeiro, IBGE. https:// geoftp.ibge.gov.br/informacoes_ambientais/vegetacao/mapas/brasil/ vegetacao.pdf.

IBGE - Instituto Brasileiro de Geografia e Estatística. 2015. Mapa Político do Estado do Pará. Escala 1:1.750.000. Rio de Janeiro, IBGE. https:// geoftp.ibge.gov.br/cartas_e_mapas/mapas_estaduais_e_distrito_ federal/politico/2015/pa_politico1750k_2015_v2.pdf.

JSTOR Global Plants. 2020. https://plants.jstor.org/. 20 Jan. 2020.

Kessler JW. 1987. A treatment of Scleria (Cyperaceae) for North America north of Mexico. SIDA, Contributions to Botany 12: 391-407.

Koyama T. 1984. Cyperaceae of Tropical America: Some new or Critical species. Acta Amazonica 14: 105-115.

Lima A. 2013. Influência da Cobertura da Terra na Extensão e Configuração Espacial de Áreas Queimadas em Anos de Seca Extrema na Amazônia Oriental. PhD Thesis. Instituto Nacional de Pesquisas Espaciais, São José dos Campos.

Lopes MNG, Souza EB, Ferreira DBS. 2013. Climatologia Regional da Precipitação no Estado do Pará. Revista Brasileira de Climatologia 12: 84-102.

Maciel-Silva JF, Nunes CS, Gil ASB. 2018. The genus Eleocharis (Cyperaceae) in the restinga of State of Pará, Brazil. Rodriguésia 69: 1813-1824.

Matzenauer W, Pereira-Silva L, Hefler SM. 2020. Cyperus in Flora do Brasil 2020. Jardim Botânico do Rio de Janeiro. http://floradobrasil.jbrj. gov.br/reflora/floradobrasil/FB7171. 01 Jun. 2021.

Mendes K, Gomes P, Alves M. 2010. Floristic inventory of a zone of ecological tension in the Atlantic Forest of Northeastern. Brazil. Rodriguésia 61: 669-676.

Moraes BC, Costa JMN, Costa ACL, Costa MH. 2005. Variação espacial e temporal da precipitação no estado do Pará. Acta Amazonica 35: 205-214.

Muasya AM, Simpson DA, Verboom GA, et al. 2009. Phylogeny of Cyperaceae Based on DNA Sequence Data: Current Progress and Future Prospects. Botanical Review 75: 2-21.

Muniz CELI, Shepherd G. 1987. O gênero Scleria Berg. (Cyperaceae) no Estado de São Paulo. Revista Brasileira de Botânica 10: 63-94.

Nees CG. 1842. Cyperaceae. In: Martius CF. (ed.) Flora Brasiliensis, enumeratio plantarum in Brasilia hactenus detectarum: quas suis aliorumque botanicorum studiis descriptas et methodo naturali digestas partim icone illustratas. Vol. II. München, Leipizig. p. 1-226.

Nelmes E. 1955. Scleria Berg., sect. Hypoporum (Nees) Endl. in Africa. Kew Bulletin 3: 415-453.
Nunes IR, Prata APN. 2013. Scleria. In: Prata APN, Amarasal MNC, Farias MCV, Alves MV. (eds.) Flora do Sergipe. Vol. I. Aracajú, Triunfo. p. 203-218.

Nunes CS, Bastos MNC, Gil ASB. 2016. Flora of the cangas of the Serra dos Carajás, Pará, Brasil: Cyperaceae. Rodriguésia 67: 1329-1366.

Nunes CS, Maciel-Silva JF, Trevisan R, Gil ASB. 2020. Eleocharis in Flora do Brasil 2020. Jardim Botânico do Rio de Janeiro. http://floradobrasil. jbrj.gov.br/reflora/floradobrasil/FB7194. 01 Jun. 2021.

Ohwi J. 1971. Contributions to the Flora of Southeast Asia V: Gramineae and Cyperaceae of Thailand. Tonan Ajia Kenkyu (The Southeast Asian Studies) 9: 194-219.

Open Library. 2018. https://openlibrary.org/. 22 Aug. 2018.

Pilger RKF. 1901. Beitrag zu Flora von Matogrosso (Schluss). In: Engler A. (ed.) Botanische Jahrbücher für Systematik, Pflanzengeschichte und Pflanzengeographie. II Helft. Vol. XXX. Whilhelm Engelmann, Leipzig. p. 129-238.

Raynal J. 1976. Notes cyperologiques. 27. Identification de deux Scleria de Poiret. Adansonia 16: 211-217.

Robinson EA. 1964. Scleria hirtella Sw. and some Allied Species: a Translantic Group. Kirkia 4: 175-184.

Santos JUM, Bastos MNC. 2014. Flores e frutos das restingas do estado do Pará. Editora da UFRA - Universidade Federal Rural da Amazônia, Belém.

Schneider LJC, Bastos MNC, Costa-Neto SV, Gil ASB. 2017. Sinópse do gênero Rhynchospora Vahl (Cyperaceae) nas restingas do estado do Pará, Brasil. Rodriguésia 68: 653-670.

Schneider LJC, Gil ASB. 2020a. Scleria in Flora do Brasil 2020. Jardim Botânico do Rio de Janeiro. http://floradobrasil.jbrj.gov.br/reflora/ floradobrasil/FB7290. 01 Jun. 2021.

Schneider LJC, Gil ASB. 2020b. Diversity of Scleria P.J.Bergius (Cyperaceae) in Amazonian restinga in State of Pará, Brazil. Rodriguésia 71. doi: 10.1590/2175-7860202071101

Silva CLB, Nunes CS, Schneider LJC, et al. 2021. Cyperaceae Juss. nos campos de natureza de Cametá, Pará, Amazônia, Brasil. Iheringia, Série Botânica 76: e2021005 doi: 10.21826/2446-82312021v76e2021005

Simpson DA. 2006. Flora da Reserva Ducke, Amazonas, Brasil: Cyperaceae. Rodriguésia 57: 171-188.

SpeciesLink R. 2019. Sistema de informação distribuído para coleções biológicas: a integração do Species Analyst e do SinBiota (FAPESP). Centro de Referência em Informação Ambiental (CRIA). http://www. splink.org.br/. 10. Dec. 2019.

Strong MT. 1994. Two new species of Scleria section Scleria (Cyperaceae) from the Neotropics. Novon 4: 296-302.

Thiers B. 2020; continuously updated. Index herbariorum: a global directory of public herbaria and associated staff. New York Botanical Garden's Virtual Herbarium. http://sweetgum.nybg.org/science/ih. 01 Jun. 2021.

Thomas WW, Weber P, Silva Filho PJS. 2020. Rhynchospora in Flora do Brasil 2020. Jardim Botânico do Rio de Janeiro. http://floradobrasil. jbrj.gov.br/reflora/floradobrasil/FB7258. 01 Jun. 2021.

Tropicos. 2019. Missouri Botanical Garden. https://www.tropicos.org. 12 Dec. 2018.

WCSP. 2018. World Checklist of Selected Plant Families. Facilitated by the Royal Botanic Gardens, Kew. http://apps.kew.org/wcsp/.12 Dec. 2018. 